UNIVERSIDADE DE SÃO PAULO

FACULDADE DE EDUCAÇÃO / INSTITUTO DE FÍSICA/

INSTITUTO DE QUÍMICA/ INSTITUTO DE BIOCIÊNCIAS

\title{
Argumentos, conhecimentos e valores em respostas a questões sociocientíficas - um caso no ensino fundamental
}

\section{ÉRICA CAVALCANTI DE ALBUQUERQUE DELL ASEM}

Dissertação de mestrado apresentada ao Instituto de Física, ao Instituto de Química, ao Instituto de Biociências e à Faculdade de Educação da Universidade de São Paulo, para a obtenção do título de Mestre em Ensino de Ciências. 
Autorizo a reprodução e divulgação total ou parcial deste trabalho, por qualquer meio convencional ou eletrônico, para fins de estudo e pesquisa, desde que citada a fonte.

\section{FICHA CATALOGRÁFICA \\ Preparada pelo Serviço de Biblioteca e Informação do Instituto de Física da Universidade de São Paulo}

Asem, Érica Cavalcanti de Albuquerque Dell

Argumentos, conhecimentos e valores em respostas a questões sociocientíficas - um caso no ensino fundamental. São Paulo, 2010.

Dissertação (Mestrado) - Universidade de São Paulo. Faculdade de Educação, Instituto de Física, Instituto de Química e Instituto de Biociências

Orientador: Profa. Dra. Silvia Luzia Frateschi Trivelato

Área de Concentração: Ensino de Biologia

Unitermos: 1. Análise do Discurso; 2. Argumentação;

3. Ensino Fundamental; 4. Filmes; 5. Valores. 


\section{Agradecimentos}

Em primeiro lugar à Deus, pela luz e inspiração que me guiaram desde os meus primeiros anos escolares até esses meses de leituras, escritas e reescritas de meu trabalho.

À minha orientadora Silvia, pelo carinho e atenção maternal e por sempre estar disposta a me ensinar os conhecimentos das diferentes ciências desde como se prepara um autêntico risoto italiano até como se faz uma revisão bibliográfica.

Aos colegas de GEPEB, Sandra, Bruno, Rafa, Rena, Paula, Dani, Sarah, Paty, Maíra, Rodrigo, Zé, Celi e Sansão, pelas conversas, risadas, inspirações, discussões sobre a "régua" do Toulmin e tardes de sexta-feira, que fechavam a semana com chave-de-ouro.

Ao Agnaldo e à Rosana, pelas contribuições em minha qualificação, para que eu pudesse chegar ao trabalho de hoje.

Às minhas professoras, Márcia e Margarida, por contribuírem diretamente em minha formação inicial na pesquisa em educação e em ensino de ciências, pelas discussões ao longo de um ano no Colégio de Aplicação da UFRJ.

Ao meu pai, minha mãe e meu irmão, que sempre me ensinaram a buscar a felicidade nas coisas simples da vida, que me mostraram o quanto é importante o conhecimento e o quanto é importante trabalhar com o que se gosta.

Ao meu verdadeiro amor e amigo, Daniel, que esteve ao meu lado desde a escolha de minha faculdade até os caminhos que me trouxeram aqui. Agradeço por toda força e incentivo nos momentos mais difíceis que passei, começando pelo Vestibular, passando por minha mudança para São Paulo até a conclusão deste trabalho, sempre iluminando meus dias e minhas tardes de domingo seja na praia ou no clube.

Aos meus fiéis amigos do Rio, Carolina, Manuela, Juliana, Conrad, Maria, Renato, Thiago e Victor, pelos anos descompromissados na escola, em que éramos felizes e não sabíamos, em que descobri minha verdadeira paixão: ser professora (não posso me esquecer dos "brothers" and "sisters" também).

Às minhas eternas amigas biológicas, Kurau, Liviete, Giba, Rênitz, Bruneca, Camis, Sammy, Mariete e Furacão (e agregados) pelos anos maravilhosos de Biologia, pelas saídas de campo, pelas discussões sobre os mistérios e explicações da natureza, por contribuírem para me tornar a bióloga que sou hoje.

Aos meus amigos "emprestados" de São Paulo, Collazo, Samantha, Paulo, Dani, Vale, Carina, Cintia, Leo, Toquinho, Dani, Fausto, Dide, Sena, Telma, Lopes, Livia, Fonseca, Sandra, Cabral e Gilara, por fazerem São Paulo ser uma cidade aconchegante, por me apresentarem bons restaurantes e por fazerem as rodadas de pôker serem bem divertidas. 
À equipe de Ciências mais comprometida e sonhadora com a qual tenho o prazer de trabalhar (Sandra, Lú, Mara, Miriam, Fú, Eraldo, Rê, Rita e Ma Rê), por todas as discussões sobre o ensino de ciências (habilidades e competências, questões-problema, metodologia científica, pré-iniciação científica), pelo compartilhamento de ideias, pelo apoio em meus projetos futuros, pelos sorrisos, pelo acolhimento, pelo espírito de família e por terem sido, direta ou indiretamente, grandes motivadores para a finalização deste trabalho.

À querida professora Carolina, minha conterrânea, que fez, com todo o carinho, a revisão ortográfica deste trabalho.

A todos os meus familiares e amigos, Solange, Marcella, Alice, Vitoria, Didi, Rodrigo, Adriana, Maria, Evelyn, Guilherme, Caroline, Graziela, Felipe e tantos outros (perto ou longe), pela paciência e compreensão nesta caminhada árdua que passei, por não poder estar muito presente e pelo pouco tempo que pude me dedicar a vocês.

Aos meus alunos de ontem, de hoje e de amanhã, por me mostrarem, todos os dias, a beleza de encantar-se com os fenômenos da natureza e a riqueza da juventude. 


\section{Resumo}

ASEM, E. C. A. D., Argumentos, conhecimentos e valores em respostas a questões sociocientíficas - um caso no ensino fundamental, Dissertação de Mestrado, Faculdade de Educação, Instituto de Biologia, Instituto de Física, Instituto de Química, Universidade de São Paulo, 2010.

Neste trabalho, analiso em que medida estudantes do $5^{\circ}$ ano do ensino fundamental de uma escola particular do município de São Paulo se apropriam dos conceitos científicos veiculados por um filme infanto-juvenil (Os Sem Floresta, 2006) na construção de seus discursos argumentativos e se, também, utilizam padrões morais e valores em seus textos por se tratar de uma questão sociocientífica. As questões sociocientíficas são aquelas que envolvem tomadas de decisões relacionando aspectos científicos, culturais, sociais e políticos, além de questões morais e éticas. Essas questões não apresentam uma solução única, definitiva e satisfatória do ponto de vista moral. O problema de desmatar uma área de floresta para a construção de um condomínio suscita diferentes olhares e opiniões sendo considerada a questão sociocientífica norteadora deste trabalho. Essa questão foi desenvolvida a partir do tema central do filme infanto-juvenil apresentado aos alunos. Os critérios de escolha do filme foram: sua linguagem dinâmica condizente com a faixa etária, sua ampla divulgação e aceitação pelo público e sua temática relacionada às questões ambientais, políticas, econômicas, sociais, éticas e culturais, contemplando os currículos com ênfase Ciência-Tecnologia-Sociedade-Ambiente - CTSA. Inicialmente é feita uma discussão sobre a análise do discurso do filme para perceber as mensagens que estão por dentro de seu discurso, com o objetivo de alicerçar a análise dos textos dos alunos. Os textos produzidos sobre a questão do desmatamento foram transcritos e analisados segundo o padrão de argumento Toulmin (2006). A partir deste referencial de análise, foram identificados valores empregados pelos alunos, como: respeito ao meio ambiente, valor à vida, ao coletivo, à cultura, à moradia e aos recursos financeiros. Os valores usados nas respostas estavam presentes no filme trabalhado, o que mostra que o filme apresenta grande influência na construção das respostas dos alunos. O respeito ao meio ambiente foi o valor que apareceu com maior frequência, mostrando uma estreita ligação das respostas com as mensagens do filme. Os alunos responderam à questão utilizando raciocínios baseados em princípios, consequências, emoção ou intuição. Os padrões morais foram categorizados segundo o padrão moral racionalista proposto por Sadler \& Zeidler (2004). A maioria das respostas apresentou consequências (Raciocínio Moral Consequencialista) para o ato de desmatar, mesma abordagem do filme. Os conceitos científicos também apareceram de forma significativa nas respostas, principalmente os conceitos que são trabalhados no filme, como: desmatamento, extinção das espécies, recursos necessários para a sobrevivência das espécies, animais como pragas naturais, cadeia alimentar, hibernação e plantio de árvores. A garantia (W), segundo o padrão de Toulmin (2006), foi o elemento do argumento que mais apresentou conceitos trabalhados no filme, mostrando que os alunos utilizam como justificativa as informações do próprio filme. A preponderância dos padrões morais, valores e conceitos científicos presentes no filme na construção das respostas dos alunos mostra o quanto as mensagens presentes nesse recurso são significativas aos alunos e passam a fazer parte de seus repertórios. 
Palavras-chave: questões sociocientíficas, argumentação, valores e padrões morais, filmes, análise do discurso. 


\begin{abstract}
ASEM, E. C. A. D., Arguments, knowledge and values in answers to socioscientific issues - a case in the Elementary School, Master's Degree Dissertation, Education College, Institute of Biology, Institute of Physics, Institute of Chemistry, University of São Paulo, 2010.
\end{abstract}

In this work, I analyze to what extent a group of students from the fifth year of the Elementary School from a private school of São Paulo appropriate the scientific concepts disclosed by a juvenile movie (Over the Hedge, 2006) to construct their argumentative discourses, and whether they also use moral patterns and values in their writings, when dealing with a socioscientific issue. The socioscientific issues involve the decision taking process related not only to scientific, cultural, social, and political aspects, but also to morals and ethics aspects. These issues do not have one unique satisfactory and definitive solution from the moral perspective. The problem of deforesting for the construction of condominium homes raises different point of views and opinions, and in this research, the socioscientific issue was considered the most important of them, and this issue was developed from the main theme of the juvenile movie seen by the students. The criteria for choosing the movie were: its dynamic language consistent with the student's age range, its broad dissemination and acceptance by the general public, and its thematic related to environmental, political, economy, social, ethical, and cultural issues, all of them contemplating the curriculum with Scientific-Technology-Society-Environment - STS emphasis. Initially a discussion about the movie's discourse analysis is done, in order to realize the messages inside its discourse, with the goal to support the analysis of the students' writings. The writings about the deforesting issue were transcribed and analyzed according to the Toulmin argument pattern (2006). From this referential analysis, values used by the students, such as respect for the environment and value for life, collective, culture, housing, and financial resources were identified. The values used in the answers were in the movie, showing that it made a huge influence on the construction of the student's answers. The respect for the environment was the value that most appeared in the answers, showing a close connection between these and the movie's messages. Students solved the questions using reasoning based on principles, consequences, emotion or intuition. The moral patterns were categorized according to the rationalist moral pattern proposed by Sadler \& Zeidler (2004). Most answers had consequences (Consequentalist Reasoning) to the deforesting act, the same approach of the movie. The scientific concepts also appeared significantly, mainly the concepts presented during the movie, such as: deforesting, species extinction, necessary resources to species survival, animals as natural pest, food chain, hibernation, and planting trees. The warranty (W), according to Toulmin pattern (2006), was the argument element with most concepts presented in the movie, showing that the students used the movie's information as justification to their answers. The strong presence in the student's answers of moral patterns, values and scientific concepts from the movie shows not only how the messages in this kind of resource are significant to the students, but also that these messages become part of their repertories. 
Key-words: socioscientific issues, argumentation, moral patterns and values, movies, discourse analysis. 


\section{SUMÁRIO}

APRESENTAÇÃO

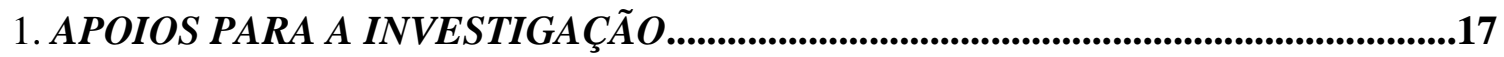

1.1 Importância da linguagem no ensino de ciências ...........................................17

1.2 As questões sociocientíficas e o ensino de ciências...........................................22

1.2.1 Questões de educação ambiental: uma realidade ...............................24

1.3 Utilização de filmes no ensino de ciências.....................................................27

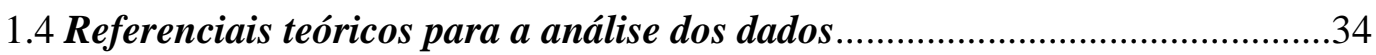

1.4.1 Como se analisam argumentos? ...........................................................

1.4.2 Como se identificam padrões morais e valores? ..................................38

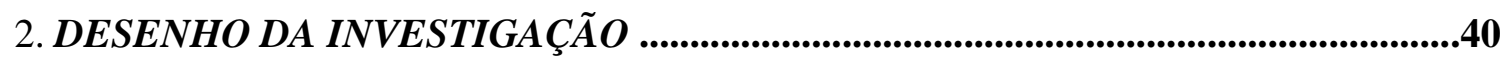

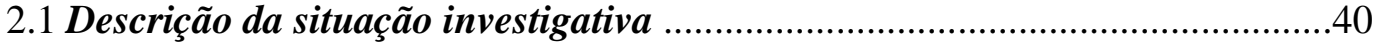

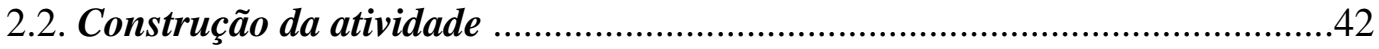

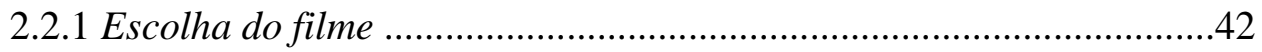

2.2.2 Proposição da atividade ..............................................................42

2.2.3 Delimitação da questão sociocientífica ............................................45

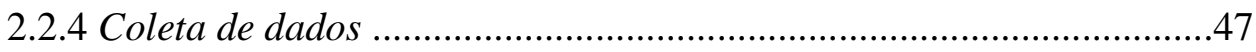

3. CONSTRUÇÃO, APRESENTAÇ̃̃O E DISCUSSÃO DOS DADOS DA INVESTIGAÇÃ $O$................................................................................................................................................48

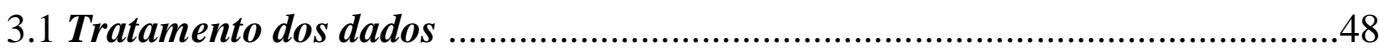

3.1.1 Transcrição, descrição das cenas do filme e categorização dos conceitos científicos e dos padrões morais e valores contidos no

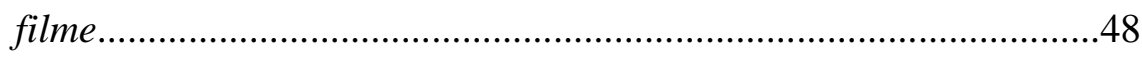

3.1.2 Análise do discurso do filme trabalhado ...........................................61

3.1.2.1 Apresentação do dado........................................................63

3.1.2.2 Descrição do dado..............................................................63

3.1.2.3 Análise do discurso..............................................................64

3.1.2.4 Em que discursos o filme se assenta?...................................65 
3.1.2.5 O que há por dentro desses discursos?

3.1.2.6 Reflexões sobre o discurso de filmes infanto- juvenis.

3.2 Análise do texto escrito dos alunos

3.2.1 Identificação dos conceitos científicos presentes nas respostas dos alunos

3.2.2 Discussão sobre os conceitos científicos empregados nas respostas dos alunos .78

3.2.3 Identificação dos conceitos científicos e das mensagens do filme nas respostas dos alunos a partir do padrão de argumentação de Toulmin (2006)

3.2.4 Discussão sobre os elementos presentes nos argumentos dos alunos

3.3 Identificação dos padrões morais e valores presentes nas respostas dos alunos .96

3.3.1 Discussão sobre os padrões morais presentes nos elementos dos argumentos dos alunos 103

3.3.2 Discussão sobre os valores empregados pelos alunos em suas respostas

3.4 Discussão sobre os posicionamentos dos alunos em suas respostas à questão sociocientífica proposta 108

4. CONSIDERAÇÕES FINAIS 110

5. REFERÊECIAS 112

5.1 Filmografia 112

5.2 Referências bibliográficas 112

6. ANEXOS. 


\section{Apresentação}

A Ciência apresenta um papel fundamental no desenvolvimento da sociedade humana. Sua contribuição destacou-se a partir da primeira metade do século XIX, quando se inicia o desenvolvimento tecnológico com o domínio das fontes de energia, de novos meios de transporte e comunicação, de armamentos e conhecimentos especializados. Já na segunda metade do século XIX à primeira metade do século XX, ocorre um salto no processo de desenvolvimento tecnológico, caracterizado pela incorporação e aplicação de novas teorias científicas, propiciando domínio e exploração de novos potenciais energéticos, como usinas hidroelétricas e termelétricas, uso de derivados do petróleo, surgimento de indústrias químicas, das fundições, usinas siderúrgicas e transportes, além dos novos meios de comunicação, como telégrafo com e sem fio, rádio, gramofone, fotografia e cinema. Nos dias de hoje, a comunicação entre as pessoas desenvolveu-se, expressivamente, por meio dos telefones fixos e móveis, dos satélites e da internet.

Além disso, os avanços científicos estão na área da Biotecnologia, como o desenvolvimento das células-tronco, a clonagem e os transgênicos e, na área ambiental, a partir de discussões sobre aquecimento global, fontes de energia renováveis e uso controlado da água, entre tantos outros temas imprescindíveis para a nossa sociedade moderna.

A partir dessa realidade, a compreensão da Ciência e de seus processos é essencial para a participação dos jovens na sociedade. Deve-se propiciar uma oferta de oportunidades educacionais reflexivas para amplas parcelas da população estudantil. A Ciência produz não só soluções para questões sociais, mas também novos problemas, como armas atômicas, que oferecem riscos à própria sobrevivência da humanidade.

Porém, quando o tema passa a ser manipulação genética, mudanças produzidas pelo homem ao ambiente, transgênicos, a situação é diferente do que na utilização de armas atômicas. A diferença é o fato de que a Ciência é incapaz de produzir um diagnóstico seguro, prevalecendo à probabilidade e não o determinismo. Assim, a Ciência passa a fazer parte da discussão em diversas instâncias governamentais, empresariais e comunitárias, dessa forma as referidas características da Ciência devem ser consideradas pelos cidadãos, que devem se posicionar em diversas situações, inclusive a eleitoral. 
Essas questões, envolvendo aspectos científicos para os quais a Ciência não apresenta uma solução única, definitiva e satisfatória, são chamadas de questões sociocientíficas. Essas questões são caracterizadas como perguntas abertas, ou seja, não possuem uma resposta definida e, normalmente, apresentam um dilema em que os alunos devem defender uma posição. Esse tipo de questão dá margem à utilização de padrões morais e valores pessoais na construção das respostas dos alunos (BELL \& LEDERMAN, 2003; SADLER \& ZEIDLER, 2004).

A formação de estudantes que possam dialogar com os diferentes campos do saber, que possam tomar decisões sobre questões sociais, ambientais, políticas e econômicas deve passar pelo âmbito da escola. Fazer com que o ensino de ciências produza condições e estímulo para uma aproximação dos jovens aos processos científicos, entendendo suas regras, seus processos e suas formas de linguagem, pode possibilitar o acesso dos jovens à cultura científica, podendo criar um diálogo entre os estudantes e os saberes das ciências.

No ensino de ciências, um dos aspectos que tem sido muito divulgado para se apresentar a linguagem científica é o uso da argumentação. Lee, Wu \& Tsai (2009) fizeram uma revisão bibliográfica de 2003 a 2007 nas revistas Journal of Science Education, Science Education e Journal of Research in Science Teaching e basearam-se nos dados que Tsai \& Wens (2005) haviam revisado nas mesmas revistas no período de 1998 a 2002. Os autores perceberam que os estudos sobre argumentação ganharam significativa atenção entre os pesquisadores da área, destacando que, dos dez artigos mais citados nessas revistas no período de 1998 a 2002, os dois primeiros tratavam sobre argumentação e que, de 2003 a 2007, tratavam sobre argumentação ( $2^{\circ}$., $3^{\circ}$. e $5^{\circ}$. lugares), raciocínio informal $\left(7^{\circ}\right.$. e $10^{\circ}$. lugares) e alfabetização científica ( $1^{\circ}$. e $9^{\circ}$. lugares). Isso mostra que as pesquisas sobre argumentação tiveram maior destaque pelos pesquisadores de 1998 a 2007. Particularmente, o raciocínio informal e a alfabetização científica receberam maior atenção dos pesquisadores de 2003 a 2007.

A construção de argumentação é uma habilidade que os estudantes podem desenvolver para resolverem problemas advindos da vida real. Pesquisadores perceberam a importância da argumentação no ensino de ciências e deram atenção a aprendizagem dos conceitos científicos a partir da argumentação (LEE et al., 2009). Driver et. al (2000) 
defendem que as questões sociocientíficas, por sua vez, auxiliam os estudantes na construção de seus discursos argumentativos.

Neste trabalho, foi analisada a construção de argumentação científica dos estudantes a partir de uma questão sociocientífica. A questão proposta foi sobre a discussão sócioambiental do desmatamento em uma área de floresta para a construção de um condomínio. Essa questão foi inspirada na temática central do filme infanto-juvenil "Os Sem Floresta" (2006). O filme foi escolhido para nortear a questão sociocientífica proposta porque acreditamos que ele traz elementos (conceitos científicos, imagens, sons, valores morais e éticos) que podem suscitar o desenvolvimento da capacidade de argumentação pelos alunos, dando a eles a capacidade de relacionarem suas experiências às problemáticas presentes em outros contextos, objetivando a formação crítica dos sujeitos e o aprendizado dos conceitos científicos.

Dentro dessa perspectiva, a pergunta principal de investigação, norteadora deste trabalho, é: em que medida os estudantes se apropriam dos conceitos científicos veiculados por um filme infanto-juvenil na construção de seus discursos argumentativos e se, também, utilizam padrões morais e valores em seus textos por se tratar de uma questão sociocientífica?

Dessa forma, para apresentar os caminhos traçados e as discussões dos dados da investigação, a estrutura dessa dissertação foi feita da seguinte maneira:

Capítulo 1: Nesse capítulo, apresento os apoios para minha investigação. Discuto a importância da linguagem e da argumentação no ensino de ciências e para a formação de jovens críticos sobre as questões sociais, políticas, econômicas e ambientais, que estejam relacionadas aos saberes científicos. Discuto, também, a relevância de se trabalhar com questões sociocientíficas, especialmente, uma questão sócio-ambiental. Baseio-me em alguns autores (DRIVER et al., 2000; JIMÉNEZ-ALEIXANDRE, 2005; KORTLAND, 1996; PATRONIS et al, 1999; ZOHAR \& NEMET, 2002; SADLER, 2004) para tratar a importância das questões sociocientíficas no desenvolvimento de argumentação. Em seguida, destaco a importância de se trabalhar com filmes em sala de aula, visando uma melhor abordagem sobre diferentes temas relacionados à Ciência, embasando minha escolha em diversos autores (ARROIO \& GIORDAN, 2006; MAIA et al., 2005; PAPPAS 
et al., 2003; FARRE et al., 2004; ROSE, 2003, 2007, REZENDE \& STRUCHINER, 2009; GOMES-MALUF \& SOUZA, 2008; MESQUITA \& SOARES, 2008; PIASSI \& PIETROCOLA, 2006, 2009; DUBCEK, 1998; FREUDENRICH, 2000; SHAW, 2000, BRAKE, 2003, DARK, 2005; PALACIOS, 2007; MACHADO, 2008; MUNEIRO \& OLIVEIRA, 2007; TOMAZI et al., 2009; KOMINSKY \& GIORDAN, 2002; SANTOS \& MORTIMER, 2009). E, por último, apresento as categorias de análise dos dados: o padrão de argumentação segundo Toulmin (2006) e os padrões morais segundo o padrão moral racionalista proposto por Sadler \& Zeidler (2004).

Capítulo 2: Discuto o desenho investigativo do trabalho, apresentando a descrição da situação investigativa, a construção da atividade, a escolha do filme infanto-juvenil trabalhado e a coleta de dados.

Capítulo 3: esse capítulo dedica-se à análise detalhada dos dados da investigação. Inicialmente, apresento a transcrição e descrição das cenas do filme. Posteriormente, para respaldar as discussões, faço a análise do discurso do mesmo, a partir da linha francesa de M. Pêcheux (KOCH, 1987) e Foucault (FISCHER, 2001). O objetivo dessa análise do discurso foi entender a linguagem, a dinâmica e a intencionalidade do material, analisando e descrevendo o que está por trás desse recurso. Em seguida, faço a análise do texto escrito dos alunos identificando os diferentes elementos que aparecem em suas respostas: os conceitos científicos, o padrão de argumentação e os padrões morais e valores. Discuto os diferentes conceitos científicos presentes nas respostas dos alunos, se são apresentados no filme ou não. Discuto como os alunos constroem sua argumentação e como as mensagens do filme se articulam no argumento. Por último, analiso a presença dos padrões morais e valores nos argumentos dos alunos.

Capítulo 4: Teço alguns comentários sobre a análise dos dados da investigação e suas possíveis implicações.

Ao final, insiro as referências bibliográficas e os anexos com as cópias das respostas dos alunos. 


\title{
1. Apoios para a investigação
}

\subsection{Importância da linguagem no ensino de ciências}

\author{
“Linguagem não é apenas uma expressão do \\ conhecimento adquirido pelos indivíduos. Existe \\ uma inter-relação fundamental entre pensamento \\ e linguagem, um proporcionando recursos ao \\ outro. Desta forma, a linguagem tem um papel \\ essencial na formação do pensamento e do \\ caráter do indivíduo.” (VYGOTSKY, 1934)
}

A linguagem pode ser caracterizada pela fala, pela escrita, pelos gestos e pelas imagens (gráficos, tabelas, fotos, desenhos e filmes), recursos que podem aparecer em diferentes contextos. Ao pensarmos no ensino de ciências, esses diferentes recursos da linguagem podem proporcionar um melhor aprendizado sobre os conceitos científicos, fazendo com que tais informações possam ser assimiladas pelos alunos, levando ao aprendizado a partir da reorganização de seus significados (JEWITT et al., 2001).

A linguagem é o recurso central para a construção das significações dos sujeitos nos diferentes campos do conhecimento. Nesse sentido, salientam Yore et al. (2003), que a linguagem é uma ferramenta para facilitar o pensamento e o raciocínio plausível, para dar sentido aos eventos do mundo natural e para resolver problemas de comunicação.

Acreditando que a aprendizagem pode ocorrer a partir da utilização dos diferentes recursos da linguagem, Lemke (2006) estuda a natureza da aprendizagem e relata que os estudantes precisam aprender como acumular e interiorizar os conteúdos em longo prazo. O autor defende que os estudantes devem ser estimulados em diferentes ambientes, como laboratórios, ambientes virtuais e ambientes naturais, para que se efetive a aprendizagem. Além disso, Lemke (2006) defende que os estudantes aprendem através de diferentes recursos, como desenhos, diagramas, gráficos, mapas, fotos, filmes, simulações 3D, entre outros, que podem ser tanto estáticos quanto dinâmicos. O autor conclui, em seu trabalho, que, o mais significativo é que o aprendizado ocorre principalmente quando os alunos fazem a relação dos diferentes significados através de todas essas modalidades, combinando texto e imagem, atividades e resumos, narrativas e observações. Toda essa interação não é automática e natural, é culturalmente específica e deve ser ensinada e aprendida. A maneira 
através da qual os alunos irão lidar com essas informações depende da natureza do campo de conhecimento a ser trabalhado em sala de aula.

No campo do ensino das ciências, a interação entre os diferentes modos de linguagem pode ser expressa através da construção da argumentação. Jiménez Aleixandre \& Bustamente (2003) defendem que a capacidade de construir argumentação com o objetivo do ensino de ciências significa reconhecer as complexas interações que têm lugar na aprendizagem, assim como reconhecer a contribuição das práticas discursivas na construção do conhecimento científico e levar em conta que fazer Ciência é também propor e discutir ideias, avaliar alternativas, eleger entre diferentes explicações e ampliar a visão da aprendizagem das ciências.

Neste projeto, defendo que a Ciência apresenta sua linguagem particular, tendo características próprias que a diferenciam da linguagem comum. Encaro a Ciência como uma forma de cultura por apresentar suas características peculiares, tais como sua construção, sua validação social e os termos específicos que compõem a sua linguagem, que chamamos de linguagem científica.

Para facilitar a introdução dos estudantes nesta cultura científica, o ensino de ciências deve utilizar diferentes práticas em sala de aula, proporcionando novos conhecimentos, além de novas linguagens, como defende Lemke (2006). Para que ocorra uma mudança na linguagem dos alunos - de uma linguagem cotidiana para uma linguagem científica -, tornando-se semelhante à linguagem do professor, os estudantes devem ter espaço para seus discursos em sala de aula. Eles devem ser encorajados, para que, assim, adquiram segurança e envolvimento com as atividades científicas. Esses discursos dos alunos devem ocorrer a partir da linguagem oral e da linguagem escrita. No discurso escrito, deve-se privilegiar a escrita argumentativa, linguagem própria da Ciência. Dessa forma, os estudantes têm a oportunidade de ensaiar um novo gênero de linguagem, que carrega consigo características da cultura científica. Assim, os estudantes entram em contato com uma nova forma de ver os fenômenos e uma linguagem específica para explicá-los. (DRIVER et al., 2000).

Bakhtin (1988) apresenta em seus estudos que a apropriação da linguagem escrita é entendida como parte do processo geral de apropriação da linguagem. Acreditando que a 
linguagem escrita é importante para a formação do pensamento dos indivíduos e que ela pode favorecer o ensino de ciências, indo ao encontro do ensino por enculturação, é importante que o ensino de ciências contemple as características peculiares da linguagem científica, dando ênfase ao discurso argumentativo.

O conhecimento científico é diferente de outros domínios, porque os enunciados, conclusões, hipóteses ou teorias não constituem meras opiniões, mas devem estar sustentados em evidências, dados empíricos ou respaldo de natureza teórica. A argumentação é definida como a capacidade de relacionar dados e conclusões, de avaliar enunciados teóricos à luz de dados empíricos ou outras fontes (KUHN, 1993). Acreditando na aproximação entre a argumentação e o fazer ciências, ensinar os alunos a construírem um discurso argumentativo para explicarem suas observações, hipóteses e conclusões sobre os dados das aulas é uma maneira de aproximá-los da prática científica, inserindo-os nessa cultura.

É através da prática da argumentação e da justificação que os indivíduos que participam de uma mesma comunidade comunicacional compartilham conhecimentos e verdades. Portanto, a argumentação é ação humana presente em todas as esferas/culturas e de fundamental importância para a formação dos indivíduos (SCARPA, 2009).

Devemos levar em consideração a pesquisa citada por Carvalho (2007), em que assuntos como ciência e tecnologia apareceram como mais interessantes à população brasileira do que política ou moda, assemelhando-se aos interessados por esportes. Nessa mesma pesquisa, 37\% não se interessam por Ciência e tecnologia por não entenderem o assunto, por isso devemos refletir em como tornar o assunto interessante. O estudo dos processos de argumentação é relevante para a aprendizagem das ciências porque a construção do conhecimento científico abrange práticas de justificação, de basear as conclusões em provas (JIMÉNEZ ALEIXANDRE, 2005). A partir da construção da argumentação, os alunos são capazes de relacionar as explicações científicas em seus contextos adequados, sem deixar de lado suas experiências anteriores (CAPECCHI et al., 2000). Consequentemente, podemos tornar os estudantes mais interessados aos assuntos de ciência e tecnologia, fazendo-os relacionar os conceitos científicos a problemas do dia-adia. 
Durante a década de 1980, houve um movimento acompanhado por um grande número de países e a Organização das Nações Unidas para a Educação, Ciências e Cultura (UNESCO), que defendia a ideia de "ciência para todos" através da educação formal e nãoformal. Esse movimento visava à formação de cidadãos críticos, capazes de entender a Ciência como parte da cultura, de procurar o próprio conhecimento científico constantemente, de questionar o conhecimento difundido pela mídia e de interagir de forma consciente com o mundo ao seu redor (CAZELLI \& FRANCO, 2001). Esse processo pode ser definido como "alfabetismo", em que há o foco no conhecimento, no entendimento e na habilidade requeridos para uma atuação efetiva na vida cotidiana em função do papel da Ciência, da Matemática e da tecnologia na vida moderna, visando uma população matemática, científica e tecnologicamente alfabetizada, para depender menos uns dos outros, diminuindo o domínio das elites cultas. A partir desses objetivos, surge o termo “alfabetismo científico", que é definido pelos países membros da OECD/PISA como: "ser capaz de combinar o conhecimento científico com a habilidade de tirar conclusões baseadas em evidências de modo a compreender e ajudar a tomar decisões sobre o mundo natural e as mudanças nele provocadas pela atividade humana" (OECD, 2000).

Há duas visões da alfabetização científica, que se complementam, segundo Brown, Reveles \& Kelly (2005): a perspectiva centrada no âmbito sociocultural dos sujeitos e a perspectiva centrada no conhecimento propriamente dito. A perspectiva centrada no âmbito sociocultural propõe a aquisição do conhecimento como parte da preparação do indivíduo para a vida social. Nessa perspectiva, a linguagem é utilizada para construir as interações, tendo lugar significativo o discurso falado e o discurso escrito. E, a perspectiva centrada no conhecimento propriamente dito propõe a inserção dos estudantes em atividades sociais, que levarão à formação do conhecimento em um segundo momento.

Segundo Fourez (2004), a perspectiva da alfabetização científica para o ensino de ciências apresenta objetivos humanistas, que visam à capacidade de se situar em um universo técnico-científico e de poder utilizar as ciências para decodificar seu mundo, tornando-o, assim, menos misterioso, mantendo sua autonomia crítica na sociedade e familiarizando-se com as grandes ideias provenientes das ciências. Essa perspectiva da alfabetização científica apresenta também objetivos ligados ao social, que são: diminuir as 
desigualdades produzidas pela falta de compreensão das tecno-ciências e ajudar as pessoas a se organizar e dar-lhes os meios para participar de debates democráticos que exigem conhecimentos e um senso crítico. Por último, há objetivos ligados ao econômico e ao político, para que os sujeitos sejam capazes de participar da produção de nosso mundo industrializado e do reforço de nosso potencial tecnológico e econômico.

Nesse sentido, diversos autores (JIMÉNEZ ALEIXANDRE \& BUSTAMANTE, 2003; CAZELLI \& FRANCO, 2001; JIMÉNEZ ALEIXANDRE et al., 2000; OSBORNE et al., 2004; SARDÀ \& SANMARTÍ, 2000; DRIVER et al., 2000; CAPECCHI et al., 2002; CARVALHO, 2007) defendem que, para que se dê o alfabetismo científico, deve-se estimular os estudantes a produzirem argumentação científica. Esses autores definem argumentação como a capacidade de relacionar dados e conclusões, de relacionar dados teóricos a partir de dados empíricos ou vindos de outras fontes. A lógica formal pode ser usada para representar ou analisar o conhecimento estabelecido, mas não é um referencial adequado para interpretar o discurso em situações em que está ocorrendo conhecimento novo.

Driver et al. (2000) contemplam argumentação como uma prática humana, seja individual ou coletiva, regida por mecanismos diferentes das regras abstratas da lógica. Esses autores distinguem entre diferentes tipos de argumentos: os argumentos retóricos e os argumentos racionais. Os argumentos retóricos apresentam razões para convencer os ouvintes, este é o maior interesse para a análise do discurso, que é um método que tem um componente subjetivo, em que diferentes pesquisadores podem interpretar de diferentes formas um diálogo ou ação. Os argumentos racionais buscam uma solução racional a um problema determinado, com a intenção de chegar a um consenso. Os autores concluem que, a capacidade de argumentação com o objetivo do ensino de ciências, significa reconhecer as complexas interações que têm lugar na aprendizagem, assim como a contribuição das práticas discursivas na construção do conhecimento científico.

É importante elaborar atividades que suscitem nos alunos o "falar ciência", fazendoos dialogarem com a cultura científica, de produção e circulação de conhecimento. 


\subsection{As questões sociocientíficas no ensino de ciências}

Acevedo et al. (2005) fazem uma revisão sobre alguns autores (BINGLE \& GASKELL, 1994; CROSS \& PIERCE, 2002; KOLSTO, 2001; ZEIDLER, 1984) que consideram importante relacionar os conhecimentos científicos escolares às questões sociais e ambientais presentes no dia-a-dia dos estudantes. Tais autores destacam que interligar estes elementos educativos apresenta grande relevância para fazer a relação entre ciência, tecnologia e sociedade - CTS - com o objetivo de aprimorar o ensino de ciências, aproximando os conhecimentos trabalhados em sala de aula à realidade dos alunos.

A essência do papel CTS na educação científica está em educar para a participação social dos sujeitos nas decisões tecnocientíficas. Esse objetivo vai ao encontro de uma finalidade do ensino de ciências: a alfabetização científica e tecnológica para todas as pessoas, que visa potencializar as atitudes democráticas dos cidadãos. O ensino de ciências não pode limitar-se a educar para conhecer e compreender melhor o mundo natural e artificial, ele deve educar, sobretudo, para que as pessoas possam intervir na sociedade (JENKINS, 1999). Uma das maneiras de alcançar o objetivo proposto anteriormente é a partir da proposição de atividades que envolvam esse tipo de questão, já que elas são apropriadas para currículos de diferentes níveis de ensino: desde o ensino fundamental até o ensino superior (SADLER \& ZEIDLER, 2004).

Questões relacionadas à biotecnologia e às mudanças ambientais devem ser consideradas como "sociocientíficas" com o objetivo de não classificarmos a Ciência e a sociedade como entidades independentes, e sim, levarmos em consideração, que a Ciência construída é intrínseca à sociedade em que está inserida (SADLER, 2004). Devemos salientar que essas questões abrangem dilemas sociais, nos quais estão presentes relações conceituais ou tecnológicas para a Ciência e para a sociedade em geral.

Os fatores que apresentam maior repercussão em pesquisas sobre tomadas de decisões sociocientíficas são os valores morais e pessoais, além dos aspectos culturais, sociais e políticos relacionados às questões propostas (FLEMING, 1986a, 1986b; PEDRETTI, 1999; ZEIDLER \& SCHAFER, 1984). As questões sociocientíficas são consideradas morais, por serem relacionadas à justiça, ao bem-estar e aos direitos da sociedade. Segundo Zeidler et al. (2002), as "questões sociocientíficas" são um termo 
amplo que abrange a abordagem CTS e considera a dimensão ética da Ciência, o raciocínio moral e o desenvolvimento emocional dos alunos.

Sadler (2004) aborda que o processo mental para resolver essas questões é melhor caracterizado pelo raciocínio informal. Esse tipo de raciocínio é utilizado pelos sujeitos para a criação dos posicionamentos em resposta a situações complexas, lembrando que essas questões não possuem respostas definidas, podendo apresentar diferentes pontos de vista entre os sujeitos. Podemos dizer que as diferenças das respostas a essas questões devem-se ao envolvimento de padrões morais e valores, que são particulares de cada um.

Para responder a uma questão sociocientífica, normalmente os indivíduos refletem sobre as causas e consequências e sobre vantagens e desvantagens, ou prós e contras da problemática abordada. Alguns autores (KUHN, 1991; JOHNSON \& BLAIR, 1991; PERKINS et al., 1983; PERKINS et al., 1991) relatam que, este tipo de questão, suscita nos indivíduos o desenvolvimento do raciocínio dedutivo, ao invés do indutivo para resolver os dilemas propostos.

O raciocínio informal está diretamente relacionado ao raciocínio moral, o qual é independente do contexto (ZEIDLER \& SCHAFER, 1984), já que os valores empregados são pessoais e culturalmente construídos, não variando de acordo com a questão apresentada. Dessa forma, Zeidler \& Schafer (1984) concluem que o raciocínio moral é um componente do raciocínio informal no contexto das questões sociocientíficas. Dessa maneira, Driver et al. (2000), Jiménez Aleixandre (2005), Kortland (1996), Patronis (1999), Zohar \& Nemet (2002) defendem que as questões sociocientíficas podem promover um contexto para o raciocínio informal e para a construção de argumentação científica.

Levando em consideração que argumentação científica é um campo de estudo que se preocupa em como os indivíduos fazem e justificam os dados e as conclusões (DRIVER et al., 2000; ZOHAR \& NEMET, 2002), as respostas aos dilemas sociocientíficos podem se caracterizar a partir de argumentos construídos de múltiplas perspectivas (SADLER, 2004). Assim, os cientistas utilizam raciocínio informal para o entendimento do mundo natural, como também baseiam-se em dados científicos para sustentar suas pesquisas, os estudantes utilizam raciocínio informal para explicitar as decisões contraditórias que tomam. O raciocínio informal é mais apropriado às questões complexas, sendo usado tanto por 
cientistas quanto por estudantes. Fazendo essa relação, alguns autores afirmam que estudar argumentação é uma maneira efetiva de acessar o raciocínio informal dos indivíduos (KUHN, 1991; MEAN \& VOSS, 1996; ZOHAR \& NEMET, 2002), o que pode ser considerado uma característica da cultura científica.

Diversos autores defendem a inclusão de questões de natureza sociocientífica no dia-a-dia da sala de aula de ciências, centrando no desenvolvimento de cidadãos responsáveis, capazes de aplicar os conhecimentos científicos aos hábitos da vida cotidiana (DRIVER et al., 2000; KOLSTO, 2001; ZEIDLER, 1984).

A atividade proposta, neste projeto de pesquisa, foi elaborada pensando na importância das questões sociocientíficas para a construção de argumentação pelos alunos. Além disso, dentre os diversos temas sociocientíficos, os dilemas ambientais podem auxiliar na investigação dos valores e padrões morais dos estudantes (OSBORNE et al, 2004; SADLER et. al, 2007, SADLER et. al, 2004; WU \& TSAI, 2007; KORTLAND, 1996). Os tópicos sociocientíficos são interessantes para a criação de atividades argumentativas no ensino de ciências, pois são assuntos que as pessoas se sentem capazes de manter opiniões e fazer julgamentos (KUHN, 1993).

\subsubsection{Questões de Educação Ambiental: uma realidade}

"Uma educação que nos leve a atuar na conservação da natureza, a entendêla, para viver com ela e nela, sem pretender dominá-la, uma educação que nos permita viver na responsabilidade individual e social, que afaste o abuso e traga consigo a colaboração na criação de um projeto nacional em que o abuso e a pobreza sejam erros que se possam e se queiram corrigir". (MATURANA, 1998).

Defino inicialmente o conceito de meio ambiente como sendo o determinado pela Conferência Intergovernamental sobre Educação Ambiental, que ocorreu em Tbilisi, Geórgia, em 1977. O primeiro grande encontro internacional para discutir o assunto afirma: "o conceito de meio ambiente abarca uma série de elementos naturais e de elementos sociais, criados pelo homem," e que "os elementos sociais constituem um conjunto de valores culturais, morais e individuais, assim como de relações interpessoais na esfera do 
trabalho e das atividades de tempo livre". Percebe-se, então, uma dimensão que vai além da biologia do "meio ambiente", dando ao conceito um perfil nitidamente socioambiental.

Segundo Loureiro (2005), a Educação Ambiental integra propostas que relacionam teorias e matrizes ideológicas distintas, sendo reconhecida publicamente em nosso país como extremamente relevante para a construção de uma perspectiva ambientalista de mundo e de sociedade. Essa prática deve constituir-se no próprio processo de atuação, identificando as diferentes esferas da vida e da sociedade que são identificadas com a questão ambiental.

No Brasil, as discussões acerca da Educação Ambiental tomaram força em meados da década de 1980, a partir da realização dos primeiros encontros nacionais, da crescente atuação das ONGs ambientalistas e de movimentos sociais e a ampliação da produção acadêmica. A importância desses debates chega à área educacional com a sua inclusão nos Parâmetros Curriculares Nacionais e na publicação da lei federal que define a Política Nacional de Educação Ambiental - PNEA - (9.795/1999). Esta reafirma um dos princípios da Educação Ambiental: "a concepção do meio ambiente em sua totalidade, considerando a interdependência entre o meio natural, socioeconômico e o cultural, sob o enfoque da sustentabilidade". Tais instrumentos legais e documentos oficiais asseguram ao tema um caráter transversal, indispensável e indissociável da política educacional brasileira. Dessa forma, não há como negar a dimensão política da Educação Ambiental na sociedade brasileira.

O bloco de Educação Ambiental chamado transformador, crítico e emancipatório é baseado nos debates clássicos da educação propriamente dita e apresenta como características principais a busca da realização da autonomia e liberdades humanas em sociedade, redefinindo o modo como nos relacionamos com a nossa espécie, com as demais espécies e com o planeta. Tem-se a convicção de que a participação social e o exercício da cidadania são práticas diretamente relacionadas à Educação Ambiental, não podendo ser desassociada de processos como produção e consumo, ética, tecnologia e contexto sóciohistórico, interesses privados e interesses públicos. Tais características são de extrema importância e relevância nos dias de hoje tendo como objetivo formar alunos cientes de seu papel na escola e na sociedade em que estão inseridos, tornando-os conscientes e críticos 
sobre sua realidade local e global, entendendo também que a transformação do todo depende de ações coletivas.

Saito (2002) salienta nos fundamentos da Política Nacional de Educação Ambiental quatro grandes desafios para a Educação Ambiental no país: a busca de uma sociedade democrática e socialmente justa, o desvelamento das condições de opressão social, a prática de uma ação transformadora intencional e a necessidade de contínua busca do conhecimento. Quando compreendemos a interdependência entre ambiente e sociedade, estamos relacionando os quatro desafios, além de servir de palco de discussões em diversas instâncias sociais, como também das características principais mencionadas anteriormente.

As mudanças devem ser feitas para o bom funcionamento do sistema, no nosso caso, a sociedade contemporânea, o capitalismo, antes que eles entrem em colapso. O que pode ser feito com a sociedade é torná-la ambientalmente sustentável e, para isso, deve-se implementar uma prática educativa crítica, cidadã e popular. Os sujeitos da sociedade (pais, alunos e professores) devem ser pensados concretamente, como parte ativa do processo social em que estão inseridos e não de modo abstrato.

De acordo com Konder (1992), a práxis é a atividade concreta pela qual o sujeito se afirma no mundo, modificando a realidade objetiva e sendo modificado, não de modo espontâneo, mecânico e repetitivo, mas reflexivo, relacionando a teoria e a prática.

Segundo Freire (1988), a práxis implica a ação e a reflexão dos homens sobre o mundo para transformá-la. Essa atividade se dá pela interação dialógica e pelas mediações que estabelecemos com o outro, a sociedade e o mundo. Assim, forma-se o objetivo central da educação, mais especificamente da Educação Ambiental, que gira em torno de conhecer, agir e se perceber no ambiente, não sendo mais um ato apenas teórico-cognitivo, mas tornando-se um processo complexo e concreto de transformação na práxis. Educar nessa prática ambiental tem como objetivo formar um cidadão capaz de dialogar e atuar em projetos distintos da sociedade, conhecendo os sujeitos sociais e trabalhando suas especificidades. A educação não é uma atividade de um sujeito pronto e constituído fora do contexto, ele deve estar inserido nas questões para ter a capacidade de dialogar e interagir com elas. 
Tal discussão acerca da sustentabilidade baseia-se em utilizar e preservar o ambiente, levando em consideração a sociedade envolvida, na busca de atitudes que podem transformar uma realidade, muitas vezes pré-determinada, nunca refletida que, após uma análise mais profunda, pode ser colocada em prática e modificada.

\subsection{A utilização de filmes no ensino de Ciências}

"Vivemos em uma época marcada por uma cultura fotocêntrica, auditiva e televisual" (AMARAL, 1997), logo, é esse aluno, cheio de informações, que está presente na realidade escolar. Dessa maneira, a utilização de filmes no ensino de ciências pode ser um estímulo ao processo de ensino-aprendizagem, tratando-se de um recurso de interesse dos estudantes, por fazer parte de seu cotidiano e apresentar uma linguagem de fácil compreensão contemplando diferentes artifícios audiovisuais.

O cinema de animação é tão antigo quanto o cinema fotográfico, nasceu no início do século XIX, com o francês Emile Cohl (1857 - 1938). Sua classificação se dá por não utilizar cenários e atores naturais, ele é a arte do movimento desenhado.

A partir de 1920, já com as técnicas e tecnologia avançadas no cinema, inclusive com a introdução do som, surgiram unidades para produção de animações que eram apresentadas na abertura das programações dos cinemas. Mas eram obras consideradas rústicas se comparadas com as atuais computadorizadas e digitalizadas. Nessa época, surgiram personagens como: Gato Felix, Betty Boop, Mickey Mouse, Pato Donald, Pateta, Popeye, Tom e Jerry, Gaguinho, Patolino e Mr. Magôo. E obras clássicas como: "Branca de Neve e os sete anões" (1937), "As viagens de Gulliver" (1939), "Pinóquio" (1940), "Dumbo" (1941) e "Bambi" (1942). Estes só surgiram por conta de seus criadores como Pat Sullivan, Walt Disney, Willian Hanna, Joe Barbera, Chuck Jones, entre outros.

Já nos anos 90 e 2000, houve a ascensão de grandes produtoras do gênero, como Pixar Animation Studios (EUA), Dreamworks (EUA), Pixar-Disney (EUA) e Aardman (Inglaterra). Nesse momento, os novos talentos criativos e artísticos utilizaram as modernas técnicas do cinema digital e procuraram fazer desenhos diferentes, lançando novas histórias e personagens, relendo fábulas e redesenhando algumas produções consideradas clássicas. 
Como produtos da evolução dos filmes de animação, podemos destacar obras como: "Monstros S/A"(2001), "Toy Story"(1995), "Formiguinha Z" (1998), "Vida de Inseto" (1998), "Ratatouille" (2007), "Fuga das galinhas" (2000), “Os sem floresta" (2006), “O Rei Leão" (1994), "Procurando Nemo" (2003), entre outros. Todos esses filmes de animação, de ampla divulgação, se caracterizam como transmissores de visão de mundo, de valores e de diferentes conceitos, que podem ser discutidos e trabalhados em diferentes disciplinas, a partir de diferentes olhares.

A utilização desses recursos como estratégia de ensino em ciências tem sido bastante defendida no meio acadêmico (ARROIO \& GIORDAN, 2006; MAIA et al., 2005; PAPPAS et al., 2003; FARRE et al., 2004; ROSE, 2003, 2007, REZENDE \& STRUCHINER, 2009; GOMES-MALUF \& SOUZA, 2008; MESQUITA \& SOARES, 2008; PIASSI \& PIETROCOLA, 2006, 2009; DUBCEK, 1998; FREUDENRICH, 2000; SHAW, 2000, BRAKE, 2003, DARK, 2005; PALACIOS, 2007; MACHADO, 2008; MUNEIRO \& OLIVEIRA, 2007; TOMAZI et al., 2009; KOMINSKY \& GIORDAN, 2002; SANTOS \& MORTIMER, 2009), uma vez que esses filmes apresentam uma linguagem dinâmica (gestos, falas, imagens, sons, personagens carismáticas, entre outros), o que leva a um fácil entendimento da temática envolvida por parte dos alunos. A maioria das pesquisas (PAPPAS et al., 2003; FARRE et al., 2004; ROSE, 2003, 2007; GOMES-MALUF \& SOUZA, 2008; MESQUITA E SOARES, 2008; PIASSI \& PIETROCOLA, 2006; MACHADO, 2008; REZENDE \& STRUCHINER, 2009), que fazem a análise desse tipo de material, concentra-se nos conceitos que estão inseridos e expostos nos filmes, abordando desde assuntos relacionados à ficção científica até a visão de ciências e a formação do estereótipo de cientista que os mesmos buscam transmitir.

Maia et al. (2005) defendem que os filmes apresentam algumas vantagens sobre a literatura como recurso de ensino, já que eles apresentam uma interação entre a linguagem visual, verbal e a escrita na transmissão de conteúdos. Os autores analisam as mensagens transmitidas pelos filmes sob ponto de vista psíquico, indicando que as mensagens acessam de maneira mais imediata o psiquismo do receptor. Dessa forma, o receptor capta as informações não só pela via intelectual ou cognitiva, como também pela via psíquica. As informações são recebidas por mais de um canal sensorial, gerando reações emocionais e 
afetivas que facilitam o processo de aprendizagem e memorização, o que leva à assimilação de forma integral e plena dos conteúdos trabalhados pelo recurso por ter sido feito para o propósito de ensino. Os autores afirmam que o cinema é um recurso de fácil acesso, prático, principalmente com o advento do videocassete e DVD, e motivador, pois associa dinamismo e motivação ao processo de aprendizagem, além de promover contato e estreitamento social. Podemos estender essa análise para o uso da internet em que vídeos podem ser acessados com grande facilidade. Nos últimos anos essa nova tecnologia está se tornando cada vez mais acessível aos professores, o que favorece a busca de novos materiais e a facilidade de trabalhá-los em sala de aula.

Os recursos comumente analisados pelos pesquisadores na área de ensino de ciências, em sua maioria, são: filmes e documentários que foram produzidos para fins didáticos, filmes que foram produzidos para fins de entretenimento e desenhos animados que envolvam assuntos relacionados ao meio científico. Essa análise permeia desde a linguagem apresentada pelo material até a formação dos conceitos que o recurso se propõe a fazer, ou, muitas vezes, o faz sem essa intenção declarada.

As análises de filmes na área de ensino de Ciências Biológicas abordam, de maneira geral, assuntos relacionados à saúde e à educação. Há trabalhos que analisam o uso desses filmes no ensino superior envolvendo temáticas relacionadas à microbiologia, genética, evolução, farmacologia, psicologia e psiquiatria (PAPPAS et al., 2003; FARRE et al., 2004; ROSE, C., 2003, 2007) e assuntos condizentes com o ensino fundamental, como a classificação dos seres vivos (REZENDE \& STRUCHINER, 2009).

Gomes-Maluf \& Souza (2008) utilizam o filme "Jurassic Park" (1993) para relacionar o ensino dos conceitos de Biologia a partir da Biologia Molecular (genética, evolução, clonagem e plantas transgênicas), fazendo um paralelo com a ficção científica abordada no filme. Em seus estudos, os autores concluíram que o uso do filme deve ser realizado antes do ensino dos conceitos, dessa forma, o material serve como um aparato desencadeador da aprendizagem e organizador dos conceitos que virão a ser explorados. Em contrapartida, o trabalho com o filme, após discutir os conceitos, gera uma insegurança em relação à validade teórica dos conceitos veiculados pelo recurso, não atingindo os objetivos esperados. Acredito que o trabalho com filmes pode ser feito em diferentes 
momentos do planejamento. O filme pode ser discutido antes da apresentação dos conceitos com o objetivo de nortear o olhar dos alunos para os temas a serem trabalhados posteriormente, nesse contexto o filme deve ser trabalhado a partir de um roteiro de observação e discussão. O filme também pode ser trabalhado durante ou depois da discussão dos conceitos, dessa forma ele tem o papel de organizador dos conteúdos.

No âmbito da discussão acerca de desenhos animados, Mesquita \& Soares (2008) discutem a visão de ciências apresentada em desenhos como "Jimmy Nêutron" e " $O$ Laboratório de Dexter", concluindo que a visão equivocada dos estudantes sobre o trabalho do cientista é reflexo das mensagens veiculadas por esses e outros desenhos, os quais apresentam uma abordagem discursiva e uma falsa representação do real. Esses autores categorizam os desenhos animados em dois grupos: os que usam os conceitos relativos à Ciência para ensinar o público telespectador (desenhos educativos), e os que não têm o compromisso com a educação, apenas usam os conceitos dentro da ludicidade da sua linguagem, dinamizando, de forma diferenciada, o texto audiovisual (desenhos criativos). Porém, essa categorização é muito categórica e não é observada na realidade. Tanto os filmes chamados educativos quanto os filmes criativos apresentam aspectos educativos e lúdicos. Muitos filmes criativos apresentam o ensino de conceitos e muitos filmes educativos são trabalhados de maneira lúdica. A finalidade do material não invalida a maneira como será abordado.

As pesquisas sobre a análise e a utilização de filmes com a temática acerca da ficção científica é bastante difundida pelos pesquisadores da área, principalmente no ensino de física. Esse tema é bastante recorrente em filmes de ampla divulgação e atrai a atenção de crianças e de jovens, devido ao interesse que eles têm por temas científicos. Diversos autores como Piassi \& Pietrocola (2006, 2009), Dubcek (1998), Freudenrich (2000), Shaw (2000), Brake (2003), Dark (2005) e Palacios (2007), defendem a utilização desse tipo de filme no ensino de física e de outras disciplinas. Esses estudos, normalmente aplicados em sala de aula, mostram que as possibilidades no ensino são inúmeras. Porém, ainda faltam estudos sistemáticos que fundamentem essa prática e permitam a análise de seus desdobramentos (PIASSI \& PIETROCOLA, 2006). 
No trabalho de Piassi \& Pietrocola (2006), há a categorização dos planos que são trabalhados em um filme de ficção científica:

- Plano conceitual-fenomenológico: são os elementos vistos como "conteúdo" escolar e podem ser distinguidos em três modalidades de elementos:

- Elementos linguísticos: o uso da linguagem, a terminologia empregada.

- Elementos objetivos: artefatos e seres, tais como máquinas, animais, plantas ou mesmo objetos de origem natural, como pedra.

- Elementos fenomenológicos: os fenômenos apresentados na história.

- Plano histórico-metodológico: está no âmbito dos "métodos de estudo da ciência e a história de sua produção" (Libâneo, 1990), envolvendo o conhecimento da estrutura e do funcionamento da prática científica, referindo-se à compreensão dos processos que levam à produção do conhecimento. Isso envolve desde a história da ciência até questões filosóficas e epistemológicas.

- Plano sócio-político: Piassi \& Pietrocola (2006) baseiam-se na noção apresentada por Libâneo (1990) - "problemas existentes no âmbito da prática social conexos com a matéria" - no sentido de incluir as múltiplas influências entre ciência e sociedade, no âmbito cultural, político, econômico e social, incluindo as influências nos dois sentidos, ou seja, da sociedade para a ciência e da ciência para a sociedade.

Piassi \& Pietrocola (2006) afirmam, nesse trabalho, que são os elementos narrativos que permitem ao autor do filme convencer o espectador de que a história em questão é dotada de verossimilhança, para que o espectador realmente "entre" na história e envolva-se com ela. Dessa forma, Piassi \& Pietrocola (2006) incluem, nessa categoria, apenas aqueles elementos de certa forma "incomuns" em um enredo cotidiano, cuja presença seja um sinalizador do gênero ficção científica e que possuem a função de situar o leitor a respeito do contexto fantástico ou inusitado da história.

$\mathrm{Na}$ transposição dessa análise para filmes infanto-juvenis, os elementos considerados "incomuns" são os animais que falam, elaboram planos, raciocinam, agem como seres humanos e têm relações emotivas entre eles. Sendo estes, os principais agentes motivadores e sensibilizadores das mensagens que o filme pretende transmitir e que exercem enorme influência nos espectadores. 
Machado (2008) analisou os conceitos científicos presentes em filmes de ficção científica com temática ambiental, os filmes analisados foram "Waterworld - o segredo das águas" (1995), “O Mensageiro" (1997), “A Corrida Silenciosa” (1972), "Impacto profundo" (1998) e “O dia depois de amanhã" (2004), concluindo que esses filmes apresentam grande influência na formação da opinião de seus espectadores e que suas discussões devem ser levadas para sala de aula, para que nenhum conceito equivocado da compreensão do filme seja formado. Além disso, o autor defende que todo filme de ficção científica auxilia na reflexão sistemática do processo de produção e distribuição dos bens culturais, o que poderá ocasionar a cultura científica tão almejada e necessária em nossos dias, pois esses filmes auxiliam na busca de implicações éticas e ambientais.

Nessa mesma linha de pesquisa, Muneiro \& Oliveira (2007) fazem a análise do discurso do filme-documentário "Uma verdade inconveniente" (2002) com o objetivo de mostrar que o discurso veiculado pelo documentário é um reflexo dos interesses pessoais e políticos do autor Al Gore, o qual generaliza um "discurso verde", de proteção e cuidado com a natureza e usa os dados da Ciência para dar credibilidade aos problemas ambientais alertados por ele. Os autores fazem uma crítica a esse discurso intencional, chamando a atenção sobre a importância de trabalhar os conceitos veiculados no filme com os alunos, para torná-los críticos e conscientes sobre a relação mídia-sociedade.

Tomazi et al. (2009) fizeram a análise de filmes de animação que contivessem estereótipos da ciência e dos cientistas e concluíram que as imagens de como se faz Ciência e dos cientistas representadas pelos filmes é a mesma que os alunos possuem, como discutido por Kominsky \& Giordan (2002). A visão de ciência e dos cientistas se forma a partir de fatos e conceitos veiculados via televisão, influenciando crianças e jovens em suas ideias a respeito do tema, mostrando que a mídia é formadora e geradora de opiniões.

“...acreditamos que as visões do mundo dos estudantes também devem ser influenciadas pelo pensamento científico e pelas expressões de sua cultura, cujos traços são parcialmente divulgados na mídia. Torna-se, então, importante investigar quais visões de ciência são transmitidas pela televisão e pelos desenhos animados, e de que maneira essas visões podem interferir na concepção de mundo dos estudantes." (Kominsky \& Giordan, 2002) 
Um filme pode trazer discussões acerca de assuntos relacionados às questões ambientais, políticas, econômicas, éticas, sociais e culturais, as quais devem aparecer em currículos com ênfase em Ciência-Tecnologia-Sociedade - CTS - com o objetivo da formação para a cidadania dos jovens estudantes, como defendem Santos \& Mortimer (2009). Trabalhar a temática ficção científica apresentada nos filmes tem um papel particularmente interessante, pois proporciona aos estudantes a relação entre a produção de conhecimento científico e o papel da Ciência na sociedade, atingindo os objetivos propostos pelo movimento CTS.

Nesse sentido, relacionar a utilização de um filme à proposição de uma questão sociocientífica, pode ser uma excelente ferramenta para a produção de argumentação pelos alunos pois, como descrevem Driver et al. (2000), as questões sociocientíficas têm a característica de suscitar nos estudantes à produção argumentativa. Além disso, se a atividade for baseada em uma problematização envolvente, os alunos têm a possibilidade de desenvolver argumentação (PATRONIS et al., 1999), sendo que tal problematização desencadeadora da atividade pode surgir a partir de situações que o filme apresenta.

Relacionar o cotidiano dos estudantes ao ensino de ciências, enfatizando o mundo de informações em que estamos culturalmente imersos é um grande desafio. Tal desafio vem sendo pensado e discutido por pesquisadores da comunidade científica da área. Lembrando que ciências está em todo lugar, nos outdoors, nas capas de revistas, nas reportagens, nos filmes, nos documentários, devemos estar atentos e despertar nos estudantes a atenção para essas diferentes formas de informações, que definitivamente constroem nossas consciências.

A utilização de recursos audiovisuais no ensino de ciências é estimulante e pode auxiliar o processo ensino-aprendizagem, já que a sua apresentação é um momento saudável, pois altera a rotina da sala de aula e permite diversificar as atividades ali realizadas. Portanto, o produto audiovisual pode ser utilizado como motivador da aprendizagem e organizador do ensino na sala de aula (ARROIO \& GIORDAN, 2006).

Os filmes são considerados recursos atrativos aos alunos por fazerem parte de seu dia-a-dia e apresentarem um apelo emocional. Suas personagens carismáticas, as trilhas 
sonoras envolventes e as imagens atraentes são recursos utilizados pelos produtores do filme com a intenção de criar uma atmosfera prazerosa aos espectadores.

Como estamos vivendo em uma sociedade bombardeada por informações de todos os lados, a chamada "era digital", Amaral (1997) destaca que devemos estar atentos às práticas de produção de sentido em que nós e nossos alunos estamos envolvidos cotidianamente na escola, nas instituições públicas, nos shoppings centers, nos cinemas, na televisão, no folclore, etc. O campo pedagógico extrapola os muros das instituições formais de escolarização e passa a ser habitado por uma variedade de instâncias culturais que produzem conhecimento, moldam comportamentos e regulam identidades.

Acreditamos na perspectiva de que aprender é uma atividade multimodal, em que há a interação entre a comunicação visual, linguística e das ações (JEWITT et al., 2001), dessa maneira, os alunos selecionam os diferentes modos semióticos. Tais escolhas são o reflexo de seus interesses na complexa mensagem transmitida por um recurso audiovisual. $O$ filme infanto-juvenil contempla diversos recursos semióticos, como a fala, a escrita, as imagens, os gestos, entre outros. Dessa forma, esses recursos podem proporcionar um melhor aprendizado sobre os conceitos científicos.

\subsection{Referenciais teóricos para a análise dos dados}

\subsubsection{Como se analisam argumentos?}

Capecchi et al. (2002) citam que a argumentação nas aulas de ciências tem sido investigada sob diferentes enfoques por Candela (1997), Driver et al. (2000) e Jiménez Aleixandre et al. (1998):

- Candela (1997) observou que os alunos se apropriam de novas formas de se expressar, principalmente quando em situações de conflito, que envolvem os alunos na busca de argumentos para validação de suas observações.

- Driver et al. (2000) sugeriram atividades estimulantes para que os alunos produzissem argumentação em sala de aula. Esses autores elaboraram categorias de 
análise a partir de um padrão de argumento desenvolvido por Toulmin (2006) (figura 1).

- Jiménez Aleixandre et al. (1998) identificaram os tipos de argumentos utilizados pelos alunos em dados, conclusões, justificativas, conhecimentos básicos, qualificadores, refutações ou oposições simples, também a partir do modelo desenvolvido por Toulmin (2006).

Esses diferentes olhares mostram que o modelo de argumentação desenvolvido por Toulmin (2006), representado na figura 1, pode ser uma rica ferramenta de análise das atividades realizadas por alunos no ensino de ciências, por isso esse referencial foi escolhido na análise dos dados desta pesquisa.

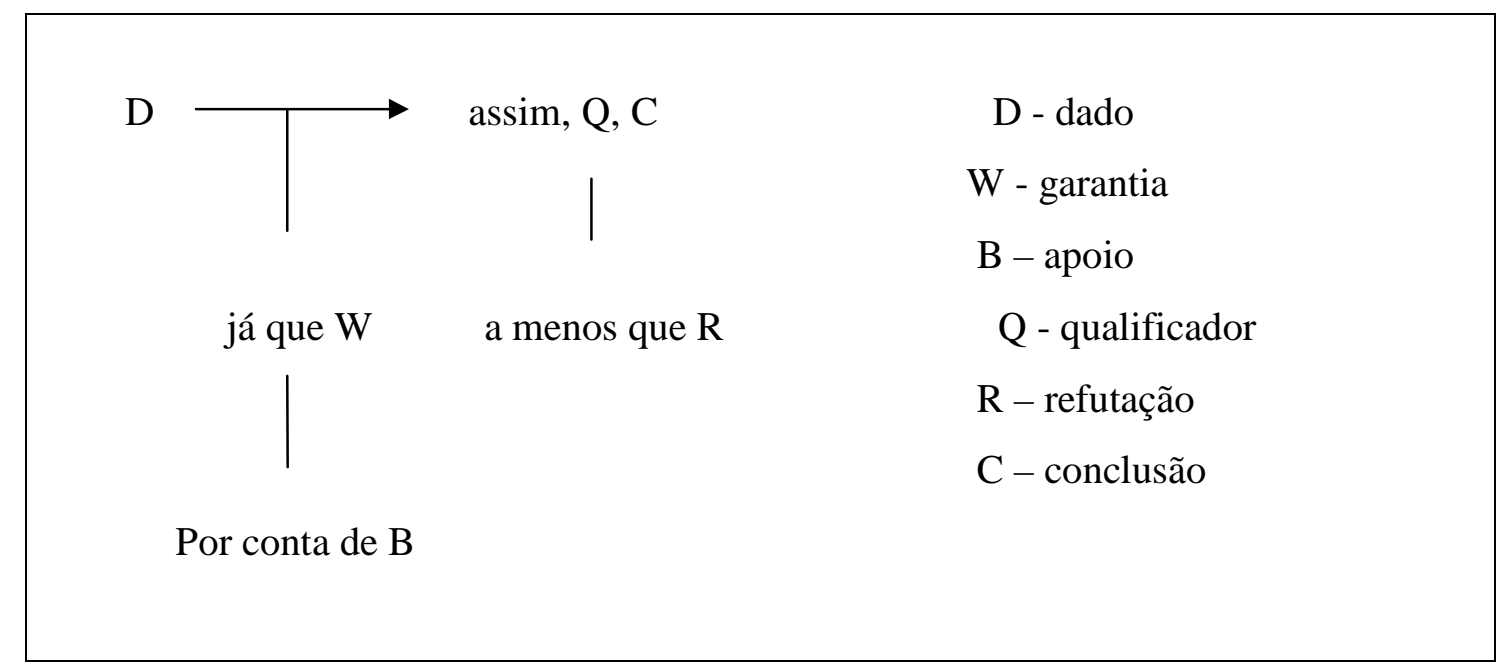

\section{Figura 1: padrão de argumento de Toulmin (2006)}

A figura 1 representa o esquema de um argumento completo. A análise do padrão de argumento baseado em Toulmin (figura 1) identifica os elementos básicos que compõem os argumentos e as relações entre esses elementos. Os elementos fundamentais são o dado, a conclusão e a garantia e podem ser acrescentados qualificadores e refutadores, o que melhora a qualidade do argumento. É possível apresentar um argumento contando apenas com os elementos fundamentais (dado, garantia e conclusão), cuja estrutura básica é: "Dado (D) que, baseado em uma garantia (W), então conclusão (C)." Se houver apenas uma conclusão pura, sem quaisquer dados apresentados em seu apoio, não pode ser considerado um argumento. 
Os dados (D) são os fatos, aos quais recorremos como fundamentos para a alegação; a conclusão (C) é a alegação, cujos méritos procuramos estabelecer; e a garantia (W), por sua vez, estabelece a relação entre os dados e a conclusão, sendo de natureza hipotética e natural. Os qualificadores modais $(Q)$ são especificações das condições necessárias para que uma dada garantia seja válida, já os refutadores (R) da garantia são as condições em que a garantia não é válida ou suficiente para dar suporte à conclusão. Os qualificadores e os refutadores dão os limites de atuação de uma determinada garantia, fazendo a ligação entre dado e conclusão.

O uso de qualificadores ou de refutadores indica uma compreensão clara do papel dos modelos na Ciência e a capacidade de ponderar diante de diferentes teorias, a partir de evidências apresentadas por cada uma delas. Um modelo, por exemplo, pode ser útil para uma situação específica, porém substituído por outro mais abrangente em outras circunstâncias.

Além dos elementos já citados, a garantia pode ser apoiada por uma afirmação categórica baseada em uma lei, jurídica ou científica. Trata-se de uma alegação que dá suporte à garantia, denominada apoio (B) ou conhecimento básico. O apoio é uma afirmação, baseada em alguma autoridade, que fundamenta a garantia.

O padrão de argumento de Toulmin estrutura o discurso argumentativo em seis elementos. Primeiro, uma conclusão (C) que é afirmada sobre a base de um dado (D). Esse passo argumentativo é autorizado por uma lei de passagem (W), ela mesma é retirada de um conhecimento de base ou apoio (B). A refutação (R) especifica as condições que invalidam tal passagem. Considerando os "pesos" dos elementos restritivos (refutação) e justificatórios (garantia e apoio), o qualificador modal (Q) atenua ou reforça o status da conclusão considerada.

Para fazer essa análise dos argumentos, deve-se ficar atento à categorização de cada elemento presente. Toulmin (2006) descreve que as garantias são de natureza mais universal que o dado. Já os dados são explícitos e as garantias, muitas vezes, implícitas, enquanto os qualificadores são a força conferida pela garantia. Há elementos que podem ser classificados como: campo-invariável, sendo válidos como recurso linguístico para todas as áreas; e campo-dependente, que têm dependência em determinada área do conhecimento. $\mathrm{O}$ 
apoio à garantia normalmente é campo-dependente. O exemplo abaixo pode explicar como são categorizados os elementos que compõem um argumento:

Dado que todas as baleias são mamíferos, já que todos os mamíferos têm pulmões, logo todas as baleias têm pulmões.

A conclusão (todas as baleias têm pulmões) é baseada na relação que se faz entre o dado (todas as baleias são mamíferos) e a garantia (todos os mamíferos têm pulmões). Percebe-se que a garantia é de natureza mais universal que o dado e que está baseada em uma alegação categórica regida por uma lei (B). Nesse caso, o apoio (B) está implícito e poderia ser caracterizado como "as categorias taxonômicas" e as "características que definem o grupo dos mamíferos". Além disso, o argumento é formalmente válido porque a premissa é verdadeira e aceita dentro do campo das ciências.

Toulmin (1993) faz uma analogia entre um texto argumentativo e um organismo: a parte anatômica são os órgãos, que são as diferentes fases do argumento, desde o enunciado inicial até a conclusão final e a parte fisiológica está constituída pela lógica de cada frase. $\mathrm{O}$ todo só tem sentido quando as partes se interrelacionam.

Não se pode classificar um argumento como formalmente válido apenas por apresentar a estrutura: dado - garantia - conclusão. A relação entre esses elementos deve ser determinada pelo campo em que está inserida e só é aceita na argumentação científica se a garantia relacionar o dado à conclusão e tiver validade no campo das ciências. Essa é a crítica que Driver et al. (2000) fazem ao modelo de argumento de Toulmin: defendem que ele analisa o discurso argumentativo de forma descontextualizada, sem levar em conta que depende do receptor e da finalidade com a qual se emite, porém é útil para entender a estrutura do argumento, mas não sua validade, a qual deve ser entendida através da campodependência.

Sardá Jorge \& Sanmartí Puig (2000) apresentam os modelos de argumentação de Toulmin (1993), Van Dijk (1978) e Adam (1992), mostrando os elementos que constituem a argumentação para cada um deles. Os autores explicitam quais as relações que devem ser estabelecidas necessariamente entre tais elementos para que ela seja válida e que tipos de sequências são características da argumentação. 
Neste trabalho, utilizaremos o padrão de argumento de Toulmin (2006), porque este admite uma maior flexibilidade para se categorizar os elementos, já que permite “conclusões concessivas" e admite que uma conclusão pode servir de dado para um outro argumento (ADAM, 1992).

Como mencionado, o modelo de Toulmin (2006) é uma ferramenta importante para a compreensão da construção da argumentação, mas somente para esse fim. Para os trabalhos envolvendo o ensino de ciências, apenas essa ferramenta de análise não é suficiente para entender as relações que se estabelecem.

Outros referenciais se mostram importantes para a discussão dos dados, a escolha de uma questão sociocientífica para o desenvolvimento da atividade discutida anteriormente e a categorização dos padrões morais e valores desenvolvidos por Sadler \& Zeidler (2004), explicados posteriormente.

\subsubsection{Como se identificam padrões morais e valores?}

Os alunos, ao construírem suas argumentações durante uma atividade, utilizam deliberações racionais sobre o assunto, comprovando que as questões sociocientíficas incentivam esse tipo de resposta. Os padrões morais racionalistas são classificados por Sadler \& Zeidler (2004) como:

- Raciocínio Moral Consequencialista: é o padrão moral representado por escolhas que levam em consideração as consequências das ações.

- Raciocínio Moral Deontológico: é o padrão moral que utiliza princípios morais como as principais garantias.

- Moral Emotiva: momento em que os alunos se colocam no lugar da pessoa fictícia que vivencia o dilema moral, há a preocupação com o bem-estar do outro e empatia.

- Moral Intuitiva: a decisão é tomada a partir da escolha moral baseada na intuição, dessa forma, os estudantes não fornecem nenhum tipo de justificativa para suas conclusões.

A relação entre as questões sociocientíficas e os diferentes tipos de padrões morais (figura 2) são mostrados abaixo no esquema elaborado por Sadler \& Zeidler (2004): 


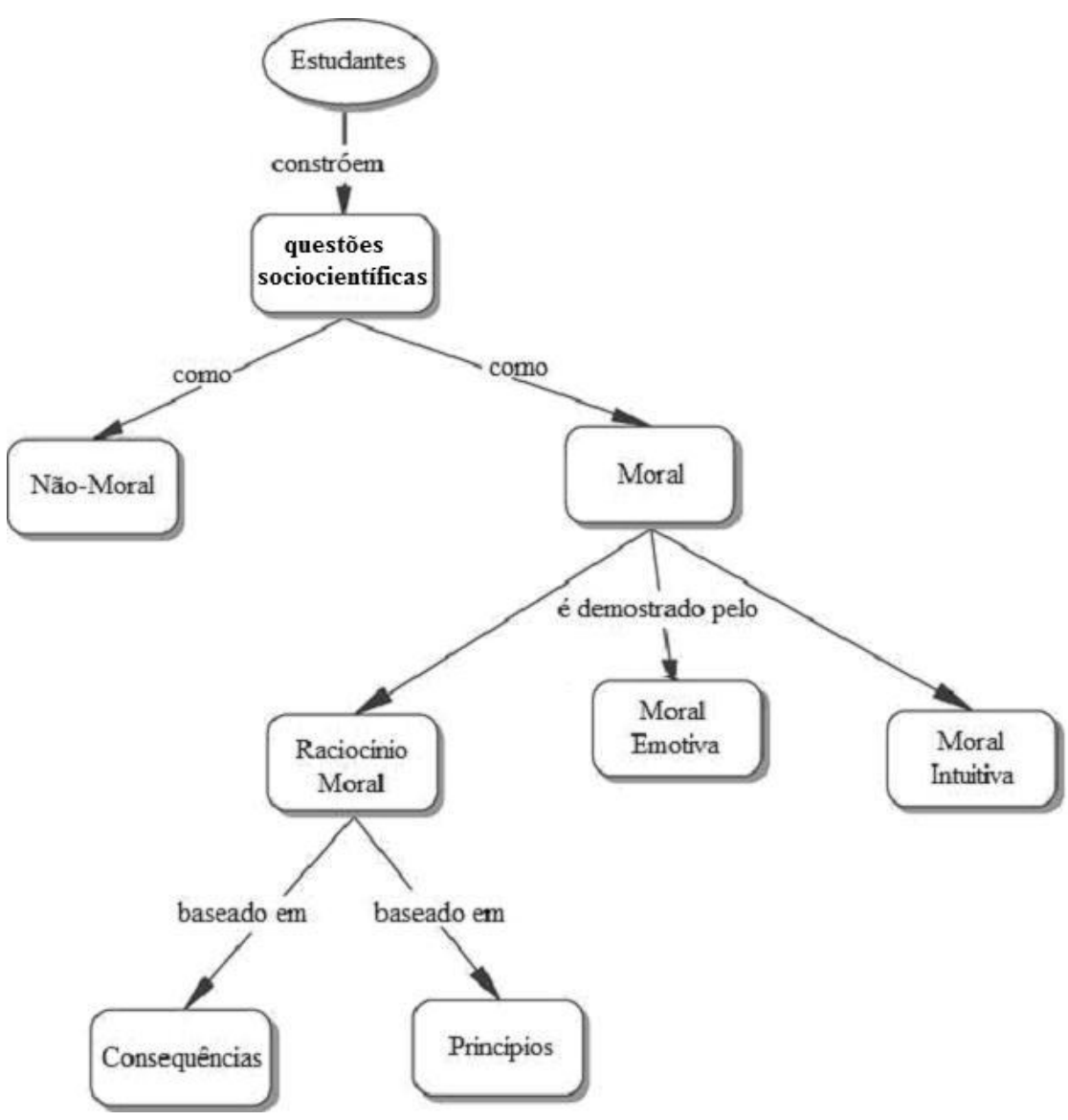

Figura 2: Visão geral dos padrões de construção e resolução dos estudantes

As questões sociocientíficas podem promover a construção de respostas que contemplem aspectos relacionados à moralidade ou não. Quando os alunos utilizam a moral para compor suas respostas, eles podem fazê-lo de modo indutivo, baseando suas justificativas em consequências às tomadas de decisão (Raciocínio Moral Consequencialista) ou em princípios (Raciocínio Moral Deontológico). Mas, por outro lado, os alunos podem argumentar utilizando apenas a emoção, ao se colocarem no lugar da pessoa fictícia (Moral Emotiva). Porém, quando os alunos respondem utilizando apenas a intuição, a estrutura não é considerada um argumento, por não apresentarem justificativas para as suas conclusões (Moral Intuitiva).

Os valores podem servir como garantias para os argumentos manifestados na discussão sobre questões morais. Essa análise e discussão só se torna possível ao categorizarmos os elementos que compõem os argumentos apresentados pelos alunos (TOULMIN, 2006). 
O trabalho de Sadler \& Zeidler (2004), que identifica os padrões morais racionalista consequencialista, racionalista deontológico, moral intuitiva e moral emotiva, representa um dos referenciais deste trabalho, que utiliza tal abordagem na análise de dados relativos a uma questão sociocientífica em um filme infanto-juvenil.

\section{Desenho da investigação}

\subsection{Descrição da situação investigativa}

Esse projeto de pesquisa foi desenvolvido em uma escola da rede particular do município de São Paulo com alunos do $5^{\mathrm{o}}$ ano do Ensino Fundamental (antiga $4^{\mathrm{a}}$ série), cuja faixa etária era de 8 a 10 anos. A mesma problematização e as mesmas atividades da sequência didática foram desenvolvidas nas três turmas da série, em que os dados da pesquisa foram coletados. Cada turma tinha 22 alunos, em média.

A organização da escola apresentava apenas uma professora por turma até o $5^{\circ}$ ano do Ensino Fundamental. Dessa maneira, as turmas escolhidas para a coleta de dados possuíam apenas uma professora, sendo esta chamada de professora polivalente, já que lecionava todas as disciplinas previstas na grade curricular.

A professora organizava os conteúdos das disciplinas a serem lecionadas a partir de questões-problema, que dinamizavam o processo de ensino-aprendizagem e serviam como o fio condutor das discussões da semana. Por vezes, essas discussões se baseavam em conteúdos de Ciências, outras vezes, História, em outras Geografia e assim por diante.

A escola propõe esse modelo de ensino defendendo os ideais construtivistas, acreditando que os alunos devem ser os agentes de suas próprias aprendizagens e que estas ocorrem quando os sujeitos são instigados a fazer perguntas e buscar suas próprias respostas. Assim, na dinâmica da sala de aula, a professora pouco recorre à lousa como material de apoio ao ensino. A construção do conhecimento se dá pelas pesquisas dos alunos à informática e à biblioteca, principalmente. As anotações dos alunos, após as discussões, são feitas em um caderno chamado de "caderno de descobertas", em que ficam registrados os dados, os fenômenos e as observações mais significativas de cada sequência de atividades. Vale ressaltar que a escola, até o $5^{\circ}$ ano do Ensino Fundamental, não adota 
livro didático de nenhuma disciplina, sendo as únicas fontes de informação dos alunos, o caderno que eles produzem, a internet e os livros da biblioteca.

É interessante salientar que essa escola está localizada em um bairro nobre do município de São Paulo, que os pais desses alunos apresentam alto grau de instrução e têm acesso a diferentes formas de informação, desde computadores, cinema, teatro, museus, entre outros. Por sua vez, os alunos possuem uma vasta bagagem cultural, tendo feito viagens para fora de São Paulo e, algumas vezes, para fora do país também.

Nessa perspectiva de ensino-aprendizagem, os conteúdos a serem trabalhados, na maioria das vezes, partem do interesse dos alunos e de assuntos que estão em foco no cotidiano deles e na mídia. Logo, no ano da coleta de dados, os assuntos mais abordados em Ciências foram: o aquecimento global, o efeito estufa, a falta de água potável no mundo, a problemática do lixo e a produção de energia.

A questão-problema que encaminhou a sequência didática até a apresentação do filme aos alunos foi: "Como o ser humano está afetando e contribuindo para o agravamento dos problemas ambientais?".

Em um primeiro momento, houve o levantamento das concepções dos alunos sobre a temática abordada, para se traçar os objetivos a serem alcançados. Muitos alunos apresentavam o conceito que a mídia contribui a formar: de que o efeito estufa ${ }^{1}$ é prejudicial ao planeta e, consequentemente, aos seres vivos. A partir dessa discussão, o grupo chegou à conclusão de que o acelerado aumento da população tem levado ao aumento da quantidade de lixo produzido e ao desmatamento de remanescentes de floresta para a construção de novas moradias.

As professoras consideraram pertinente trazer uma linguagem diferente para ilustrar a problemática em discussão, por isso a escolha do filme "Os sem floresta" (2006). Esse filme é condizente com a faixa etária dos alunos, apresenta uma linguagem descontraída e aborda os assuntos referentes à discussão da sala de aula. A construção da atividade e a coleta de dados serão explicadas no próximo capítulo.

\footnotetext{
${ }^{1}$ Define-se o efeito estufa como o processo natural de retenção de radiação solar pelos gases carbônico e metano na atmosfera do nosso planeta e que, a partir disso, pôde haver o surgimento de vida. Já o aquecimento global, é o aumento acelerado dos níveis de gás carbônico e gás metano, que estão mantendo maior quantidade de radiação solar na atmosfera, dessa forma a temperatura global está aumentando.
} 
Como fechamento da sequência didática, após a atividade do filme, foi proposta uma atividade denominada "Júri Simulado", em que os alunos defendiam seus pontos de vista sobre a questão proposta, tentando, para isso, convencer um júri, apresentando argumentos embasados em fatos reais e em fatos presentes no filme. Essa atividade, por ser de outra natureza ao ser comparada com as produções escritas, não foi analisada nesse projeto de pesquisa.

\subsection{Construção da atividade}

\subsubsection{Escolha do filme}

O filme escolhido para a proposição da atividade foi "OS SEM FLORESTA" (2006). Esse filme contém questões voltadas para o ensino de ciências, em que o conteúdo diegético $^{2}$ aborda o tema do desmatamento para a construção de moradias para os seres humanos e suas principais consequências ao meio ambiente. Além de ser apresentado em forma de animação, que é condizente com a faixa etária desses alunos.

Esse tipo de filme tem um grande apelo para o público infanto-juvenil por sua linguagem dinâmica. É importante registrar que o filme selecionado teve grande audiência, dos 66 alunos que participaram da pesquisa, apenas 9 não haviam assistido ao filme anteriormente, o que mostra a importância de trazer esse tipo de material para a sala de aula e, principalmente, analisar uma questão de investigação acerca dele. É importante registrar que este tipo de material não foi produzido com o objetivo de ensinar ciências, e sim, de trazer entretenimento ao público em geral.

\subsubsection{Proposição da atividade}

O trabalho foi realizado em três turmas diferentes do $5^{\circ}$ ano do Ensino Fundamental, caracterizadas, nesta pesquisa, como 1, 2 e 3. A atividade foi encaminhada pelas próprias

\footnotetext{
${ }^{2}$ Segundo Napolitano (2003), o conteúdo diegético significa a história contada pelo filme e consequente realidade fílmica implicada.
} 
professoras dos alunos, as quais são responsáveis por todas as disciplinas da série, sendo chamadas de professoras polivalentes. Por conta disso, os alunos não as caracterizam apenas como professoras de ciências, o que consideramos importante para o desenvolvimento da atividade, pois, assim, os alunos não tentam interpretar qual seria a “intenção" por detrás da atividade, tentando dar as respostas que as professoras "gostariam de ouvir", como já foi observado por Jiménez et al. (2000).

O trabalho foi dividido em duas etapas: na primeira, foi passado o filme infantojuvenil "OS SEM FLORESTA", que tem duração de 1 hora e 20 minutos, na segunda etapa, os alunos foram divididos em seis grupos, nos quais deveriam discutir e elaborar uma carta defendendo o ponto de vista do segmento da sociedade/ambiente que estavam representando. Como cada turma possuía, em média, 22 alunos, cada grupo tinha três ou quatro alunos.

Nesta segunda etapa, a atividade chamava-se "Carta à Prefeitura" e foi pedido aos alunos que lessem o texto de introdução da atividade. Esse texto era o mesmo para todos os seis grupos de alunos. O texto de introdução da atividade segue abaixo e foi desenvolvido pelas próprias professoras das turmas:

"Vocês acabaram de assistir a um filme que aborda uma questão ambiental muito comentada nos dias de hoje.

Imaginem que, na cidadezinha em que moram, a prefeitura está prestes a decidir se permite ou não a construção de um condomínio com luz elétrica, saneamento básico e lazer. Mas, para isso, deverá desmatar uma área de floresta. Então, o prefeito pede aos interessados que escrevam uma carta ressaltando todos os pontos positivos e negativos dessa construção, explicando cada um deles. Dessa maneira, conhecendo todos os pontos de vista, o prefeito poderá tomar a melhor decisão.”

Nessa etapa, em que os alunos foram instigados a desenvolver um texto argumentativo para responder à questão levantada, cada grupo deveria representar um dos segmentos da sociedade/ambiente apresentados. Os seis segmentos da sociedade/ambiente estão listados abaixo: 
- os animais que vivem na floresta: a sigla para representá-los será AN

- as pessoas que moram na cidade sem as mínimas condições necessárias: a sigla para representá-los será PE

- os comerciantes da cidade: a sigla para caracterizá-los será CC

- a comunidade que retira seu sustento dessa floresta: a sigla para caracterizá-los será CM

- o movimento ambientalista: a sigla para caracterizá-los será MA

- os trabalhadores da construtora de condomínios: a sigla para representá-los será TR

Esses segmentos foram selecionados pelas próprias professoras por acreditarem que os pontos de vista para cada um deles é diferente, havendo grupos possivelmente a favor da construção do condomínio e grupos que se posicionariam, possivelmente, contra a construção. Analisar os diferentes pontos de vista é interessante para perceber o quanto os padrões morais e os valores estão enraizados nos alunos e o quanto pode-se abrir mão de seus princípios para fazer o que a atividade pede.

O papel de cada segmento da sociedade/ambiente a ser representado foi explicado pelas professoras aos alunos, os quais não tiveram dificuldade em entender qual era a função de cada um na atividade proposta.

A questão levantada dá margem para uma vasta discussão sobre os aspectos positivos e negativos da construção do condomínio, o que deve ter relação direta com o grupo social representado e o filme assistido. Essa questão foi elaborada com o intuito de suscitar argumentação científica dos alunos, já que, para solucioná-la, os alunos precisam listar os pontos positivos e negativos (possíveis dados, garantias, apoios e refutadores), explicando cada um deles (possíveis garantias, apoios e conclusões). Acreditamos que, ao elaborarem suas respostas, os estudantes também lançam mão de seus padrões morais e valores pessoais, caracterizando, por sua vez, como uma questão sociocientífica ou sócioambiental. 


\subsubsection{Delimitação da questão sociocientífica ou sócio-ambiental}

O texto da atividade foi elaborado com o objetivo de apresentar o problema que deveria ser discutido nos grupos. A questão norteadora da atividade apresentava a mesma problemática do filme: o desmatamento de uma área de floresta para a construção de um condomínio. Porém, o ponto de vista a ser defendido dependia do segmento da sociedade/ambiente que o grupo estaria representando, conforme explicado anteriormente.

Assim, baseando-nos nesta abordagem, trabalhamos com uma questão de Educação Ambiental a partir da perspectiva sócio-ambiental, contemplando aspectos econômicos, políticos e ambientais para, então, analisar a influência do filme selecionado para a atividade (OS SEM FLORESTA, 2006) nas respostas dos estudantes à questão levantada.

As discussões suscitadas a partir da questão sócio-ambiental proposta, estimularam a presença de juízos de valor, que podem ser apresentados como valores morais e éticos nas respostas dos estudantes.

"Como as questões envolvidas com o meio ambiente dizem respeito à vida e à sobrevivência de todos os seres do planeta, tais questões - e os valores a elas associados - abrangem muito mais que opções pessoais. Nesse caso, deve ser explícita nossa posição em favor desses valores, que denomino valores ambientalmente desejáveis, constituindo-se mais uma base possível de trabalho relativo aos valores universalmente desejáveis" (BONOTTO, 2008).

A problemática proposta (se os alunos são contra ou a favor o desmatamento em uma área de floresta para a construção de um condomínio) foi desenvolvida com o objetivo de suscitar argumentação dos estudantes ao desenvolverem suas respostas, por ser uma questão sócio-ambiental e, além disso, estar presente em um filme infanto-juvenil. A relação afetiva com os personagens do filme e a familiaridade com a questão levantada fazem os alunos refletirem e responderem utilizando, para isso, seus valores pessoais, morais e éticos.

Acreditando que os diferentes recursos semióticos (gestos, falas, imagens e sons) estimulam o aprendizado dos conceitos científicos e dos padrões morais e valores veiculados no filme, pretendemos analisar em que medida os alunos se apropriam de tais conceitos e padrões ao elaborarem suas respostas e construírem argumentação científica. 
A atividade proposta pode ser caracterizada como uma questão sociocientífica ou sócio-ambiental, já que, para ser respondida, podem-se utilizar padrões morais e valores contidos no filme ou presentes nos próprios sujeitos. Esse tipo de questão pode auxiliar os estudantes na construção de seus discursos argumentativos, como defendem Driver et. al (2000). Estas questões são caracterizadas como perguntas abertas, ou seja, não possuem uma resposta definida e, normalmente, apresentam um dilema em que os alunos devem defender uma posição.

Nesse sentido, a contextualização da questão tem o objetivo de promover maior envolvimento dos estudantes porque a questão apresenta uma problemática próxima à realidade deles, uma problemática abordada num filme que tem grande apelo por sua dinâmica e linguagem. Patronis et al. (1999) concluíram que os alunos são aptos para formular argumentos e atingir decisões quando encontram uma situação com a qual realmente estão envolvidos. Assim, ligações pessoais com as questões discutidas poderiam levar a habilidades argumentativas melhoradas.

Dessa forma, os estudantes são instigados a tomar uma decisão sobre determinado assunto, utilizando, para isso, justificativas para embasar suas conclusões. Os trabalhos de Bell \& Lederman (2003) e Sadler \& Zeidler (2004) mostram que os estudantes baseiam suas decisões, primariamente, em valores pessoais e preocupações sociais, como também em questões morais e éticas.

Essa atividade é considerada uma questão sociocientífica por se tratar de uma questão voltada à mudança ambiental (desmatamento de uma área de floresta para a construção de moradias), apresentando diferentes dilemas sociais e ambientais. Dessa maneira, os alunos foram instigados a apresentar argumentos contra e a favor à construção de um condomínio em uma área de floresta. Nesse contexto, um dos focos do trabalho está na investigação e análise dos valores e padrões morais que os alunos apresentaram em suas respostas, os quais foram categorizados segundo o padrão moral racionalista proposto por Sadler \& Zeidler (2004).

A análise dos textos produzidos pelos alunos é o resultado da mediação da questão sociocientífica com as mensagens passadas pelo filme, entendendo que a variação dos textos se dá pelas diferentes formas de interpretação que cada aluno apresenta. As respostas 
dos estudantes podem conter conceitos científicos presentes no filme, além do emprego de padrões morais e valores, que são estimulados a aparecer, por se tratar de uma questão de natureza sociocientífica.

Como a intenção da atividade é que os alunos escrevam uma carta para convencer o leitor sobre sua opinião (destruição ou não da floresta), o texto argumentativo cumpre bem esse papel, já que apresenta os elementos fundamentais: justificação e conclusão.

\subsubsection{Coleta de dados}

Os dados foram coletados em novembro de 2008 em horário normal de aula dos alunos. A pesquisadora esteve presente em atividades anteriores para que os alunos ficassem familiarizados com ela, objetivando minimizar qualquer interferência nos resultados da pesquisa.

O papel da pesquisadora foi apenas o de registrar as atividades em áudio e vídeo. O vídeo teve o objetivo de mostrar a dinâmica da turma na elaboração da atividade, enquanto o áudio registrou a discussão dentro dos grupos para a preparação das respostas finais. Foi colocado um gravador digital em cada grupo, totalizando seis gravadores, para facilitar o entendimento das falas em um momento oportuno. As falas dentro dos grupos não foram transcritas, por não representarem, nesse momento, o objetivo do trabalho.

Os grupos de alunos, representando cada segmento da sociedade/ambiente, elaboraram uma carta explicitando seus pontos de vista sobre a construção do condomínio, a qual foi entregue como produto final da atividade. Essas cartas foram digitadas para facilitar a análise e categorização dos argumentos dos alunos, os quais tiveram o papel de responder a pergunta de investigação desse projeto de pesquisa. As cartas originais foram digitalizadas e estão nos anexos desse trabalho.

Além disso, os conteúdos científicos e os valores presentes no filme também foram significativos para a análise das respostas dos alunos por isso as falas dos personagens foram transcritas e as cenas foram descritas e comentadas sob o ponto de vista dos conceitos científicos, padrões morais e valores contidos em cada uma delas. 


\section{Construção, apresentação e discussão dos dados da investigação.}

\subsection{Tratamento dos dados}

3.1.1 Transcrição das principais falas, descrição das cenas e categorização dos conceitos científicos e padrões morais e valores contidos no filme

Os três episódios selecionados para a transcrição das principais falas, descrição das cenas e categorização dos conceitos científicos e dos padrões morais e valores são os episódios principais que ocorrem logo no início do filme. Eles foram escolhidos por serem as cenas que dão encaminhamento ao filme e por apresentarem os conceitos científicos principais. Os conceitos presentes no filme foram analisados do ponto de vista científico que, de alguma maneira, remetam a natureza da ciência. Já os padrões morais e valores foram categorizados levando em consideração os valores passados pelo filme e as preocupações sociais e ambientais por trás do seu discurso.

Para estabelecer a relação entre os conceitos ou os valores destacados em cada trecho do filme, optei por fazer uma marcação em itálico no trecho do filme, que se remete ao conceito ou valor apresentado, numerando os trechos do filme, seus respectivos conceitos científicos e seus respectivos conceitos ou valores, para facilitar a análise posterior dos dados.

As cenas não descritas e categorizadas apresentam o desenrolar de aventuras a que os personagens são expostos, desde explosões, perseguições de carro até a destruição de casas no condomínio, caracterizando o gênero do material e o público-alvo do filme. 
Filme: OS SEM-FLORESTA (2006)

\begin{tabular}{|c|c|c|}
\hline $\begin{array}{l}\text { NOME DOS } \\
\text { PERSONAGENS } \\
\text { (EM ORDEM } \\
\text { ALFABÉTICA) } \\
\end{array}$ & $\begin{array}{l}\text { ANIMAIS QUE } \\
\text { REPRESENTAM }\end{array}$ & $\begin{array}{l}\text { CARACTERÍSTICAS DOS } \\
\text { PERSONAGENS }\end{array}$ \\
\hline $\begin{array}{l}\text { Bucky, Quillo e } \\
\text { Spike }\end{array}$ & $\begin{array}{l}\text { Porcos-espinhos } \\
\quad \text { (Filhotes) }\end{array}$ & $\begin{array}{l}\text { Sempre falam e agem juntos, são muito } \\
\text { espertos e sabem "usar" os eletrônicos dos } \\
\text { humanos. }\end{array}$ \\
\hline Estela & Gambá & $\begin{array}{l}\text { Sempre está mal humorada e não gosta de se } \\
\text { relacionar com os outros. Tem um odor bem } \\
\text { forte característico dos gambás. }\end{array}$ \\
\hline Hammy & Esquilo & $\begin{array}{l}\text { Ele está sempre atrás de comida, é muito } \\
\text { "elétrico" e gosta dos salgadinhos dos } \\
\text { humanos. }\end{array}$ \\
\hline Heather & Sariguê (filha) & $\begin{array}{l}\text { É uma espécie parecida com gambá. Ela tem } \\
\text { dificuldades em fingir que está morta em uma } \\
\text { situação de estresse, característica importante } \\
\text { para a sobrevivência da espécie. Ela sente a } \\
\text { falta da mãe. }\end{array}$ \\
\hline Lou e Penny & $\begin{array}{l}\text { Porcos-espinhos } \\
\text { (pai e mãe) }\end{array}$ & $\begin{array}{l}\text { São muito alegres e estão sempre cuidando de } \\
\text { seus filhotes. }\end{array}$ \\
\hline Ozzie & Sariguê (pai) & $\begin{array}{l}\text { É uma espécie parecida com gambá. Ele } \\
\text { cuida sozinho de sua filha, Heather, já que a } \\
\text { mãe morreu. Ele ensina a filha a como se } \\
\text { fingir de morta em uma situação de estresse, } \\
\text { característica importante para a sobrevivência } \\
\text { da espécie. }\end{array}$ \\
\hline RJ & Guaxinim & $\begin{array}{l}\text { Ele é um dos protagonistas. Ele é o "vilão" da } \\
\text { história. Ele é ameaçado pelo urso Vincent e } \\
\text { tem que juntar comida para o urso até o final } \\
\text { de sua hibernação. Ele inventa um plano, } \\
\text { mente e envolve os outros animais da floresta } \\
\text { para conseguir juntar a comida necessária } \\
\text { para o urso, para não ser morto por Vincent. }\end{array}$ \\
\hline Verne & Tartaruga & $\begin{array}{l}\text { Ele é um dos protagonistas, é o "mocinho" da } \\
\text { história e é o líder do grupo de animais da } \\
\text { floresta. Ele é o único que percebe que RJ } \\
\text { quer enganá-los. Ele tenta alertar os outros } \\
\text { animais, que não acreditam nele e ficam do } \\
\text { lado de RJ. }\end{array}$ \\
\hline Vincent & Urso & $\begin{array}{l}\text { Ele é o predador da história, capaz de comer } \\
\text { qualquer um dos animais da floresta. Porém, } \\
\text { para não fazer isso, ele opta por comer a } \\
\text { comida dos humanos, que RJ precisa juntar. }\end{array}$ \\
\hline
\end{tabular}




\section{Cena 1}

\begin{tabular}{|c|c|c|c|}
\hline $\begin{array}{l}\text { Trechos das } \\
\text { cenas } e \\
\text { minutagem }\end{array}$ & $\begin{array}{l}\text { Transcrição de algumas falas } e \\
\text { descrição das cenas do filme }\end{array}$ & $\begin{array}{c}\text { Conceitos } \\
\text { científicos } \\
\text { contidos nas } \\
\text { cenas }\end{array}$ & $\begin{array}{c}\text { Padrões morais } \\
\text { e valores } \\
\text { contidos nas } \\
\text { cenas }\end{array}$ \\
\hline $\begin{array}{c}01 \\
01 ' 30 "\end{array}$ & $\begin{array}{l}\text { RJ tenta roubar as reservas de comida } \\
\text { de Vincent, quando ele está hibernando } \\
\text { (1). Essas reservas eram alimentos } \\
\text { industrializados e salgadinhos (2), que } \\
\text { o urso pegou dos seres humanos que } \\
\text { visitavam o parque. }\end{array}$ & $\begin{array}{l}\text { (1) Ursos } \\
\text { hibernam } \\
\text { (hibernação). } \\
\text { (2) Hábito de } \\
\text { alimentação dos } \\
\text { animais } \\
\text { semelhante a dos } \\
\text { seres humanos. }\end{array}$ & \\
\hline $\begin{array}{c}02 \\
\text { 03'30' }\end{array}$ & $\begin{array}{l}\text { Vincent acorda, pegando RJ em } \\
\text { flagrante, que deixa o carrinho com } \\
\text { todos os suprimentos roubados (1) de } \\
\text { Vincent ser atropelado por um } \\
\text { caminhão. }\end{array}$ & & $\begin{array}{l}\text { (1) O roubo é } \\
\text { mostrado como } \\
\text { algo errado. }\end{array}$ \\
\hline $\begin{array}{c}03 \\
04 ' 30 "\end{array}$ & $\begin{array}{l}\text { Vincent fica furioso e vai comer RJ (1), } \\
\text { quando, então, RJ promete recuperar } \\
\text { todos os alimentos perdidos no prazo de } \\
\text { uma semana. Tempo restante para que } \\
\text { Vincent saia da hibernação (3), o que } \\
\text { seria na próxima lua cheia. }\end{array}$ & $\begin{array}{l}\text { (1) Cadeia } \\
\text { alimentar. } \\
\text { (3) Tempo } \\
\text { necessário para a } \\
\text { hibernação. }\end{array}$ & $\begin{array}{l}\text { (2) A promessa } \\
\text { deve ser } \\
\text { cumprida. }\end{array}$ \\
\hline $\begin{array}{c}04 \\
05 ' 52,\end{array}$ & $\begin{array}{l}\text { RJ fica vagando pelo parque atrás de } \\
\text { alimentos (1), ele revira o lixo (pacotes } \\
\text { de salgadinhos, restos de alimentos), } \\
\text { que está jogado por todas as partes (2), } \\
\text { mas não encontra nada significativo. }\end{array}$ & $\begin{array}{l}\text { (1) Os animais } \\
\text { consomem restos } \\
\text { de alimentos } \\
\text { deixados pelos } \\
\text { humanos. } \\
\text { (2) As pessoas } \\
\text { produzem grande } \\
\text { quantidade de } \\
\text { lixo, cada } \\
\text { alimento é } \\
\text { armazenado em } \\
\text { um pacote } \\
\text { descartável, que é } \\
\text { descartado. }\end{array}$ & $\begin{array}{l}\text { (2) O filme faz } \\
\text { uma crítica às } \\
\text { pessoas que não } \\
\text { têm consciência } \\
\text { e deixam o lixo } \\
\text { no parque. } \\
\text { Além disso, } \\
\text { também critica } \\
\text { as embalagens } \\
\text { descartáveis. }\end{array}$ \\
\hline $\begin{array}{c}05 \\
\text { 07'10'” }\end{array}$ & $\begin{array}{l}\text { Então, depara-se com um "outdoor" de } \\
\text { propaganda de um novo condomínio, } \\
\text { "El Rancho Camelot", e vê também um } \\
\text { encarte de supermercado com os } \\
\text { produtos que precisa. Assim, relaciona } \\
\text { o condomínio aos produtos que precisa }\end{array}$ & $\begin{array}{l}\text { (1) Animais } \\
\text { silvestres como } \\
\text { pragas naturais, } \\
\text { decorrente da } \\
\text { ausência de seu } \\
\text { habitat natural, } \\
\text { falta de seu }\end{array}$ & \\
\hline
\end{tabular}




\begin{tabular}{|l|l|l|l|}
\hline e vai para lá (1). & próprio alimento, \\
& e proximidade & das casas dos \\
& seres humanos, \\
& onde vão em \\
busca de & alimento. & \\
& & \\
\hline
\end{tabular}

Cena 2

\begin{tabular}{|c|c|c|c|}
\hline $\begin{array}{l}\text { Trechos das } \\
\text { cenas } e \\
\text { minutagem }\end{array}$ & $\begin{array}{c}\text { Transcrição de algumas falas e descrição } \\
\text { das cenas do filme }\end{array}$ & $\begin{array}{c}\text { Conceitos } \\
\text { científicos } \\
\text { contidos nas } \\
\text { cenas }\end{array}$ & $\begin{array}{c}\text { Padrões morais } \\
\text { e valores } \\
\text { contidos nas } \\
\text { cenas }\end{array}$ \\
\hline $\begin{array}{c}01 \\
07 ' 15 ’\end{array}$ & $\begin{array}{l}\text { A primavera acaba de começar. Os } \\
\text { animais da floresta saem da hibernação } \\
\text { (1). Eles ficaram protegidos contra o frio, } \\
\text { durante todo o inverno, dentro de um } \\
\text { tronco de árvore, com todo o alimento que } \\
\text { haviam coletado nas estações anteriores } \\
\text { (2). Todos estão famintos porque o tronco } \\
\text { já se encontra vazio. (3) }\end{array}$ & $\begin{array}{l}\text { (1) Início da } \\
\text { primavera é final } \\
\text { de hibernação, ou } \\
\text { seja, final do } \\
\text { inverno. O frio } \\
\text { acabou. } \\
\text { (2) Durante a } \\
\text { hibernação, os } \\
\text { animais se } \\
\text { protegem do frio } \\
\text { e se alimentam de } \\
\text { comidas } \\
\text { armazenadas } \\
\text { antes do inverno, } \\
\text { coletadas por eles } \\
\text { no ambiente em } \\
\text { que vivem. } \\
\text { (3) Quando saem } \\
\text { da hibernação, os } \\
\text { animais estão } \\
\text { famintos. }\end{array}$ & \\
\hline $\begin{array}{c}02 \\
10 ' 00 "\end{array}$ & $\begin{array}{l}\text { Nesse momento, RJ está passando pela } \\
\text { floresta e vê os animais conversando } \\
\text { sobre armazenar comida para o próximo } \\
\text { inverno (1). Então, ele sobe em uma } \\
\text { árvore e fica observando a conversa } \\
\text { deles, pensando como poderia utilizar } \\
\text { esses animais (2), que se chamam de } \\
\text { "coletores" (1), para conseguir todas as } \\
\text { comidas que perdeu de Vincent. }\end{array}$ & $\begin{array}{l}\text { (1) Os animais } \\
\text { fazem planos e se } \\
\text { organizam para } \\
\text { armazenar comida } \\
\text { para o período de } \\
\text { hibernação. } \\
\text { Os animais } \\
\text { chamados } \\
\text { "coletores" fazem }\end{array}$ & $\begin{array}{l}\text { (1) A } \\
\text { importância do } \\
\text { trabalho em } \\
\text { grupo. } \\
\text { (2) A ideia de } \\
\text { RJ usar os } \\
\text { animais } \\
\text { "coletores" a } \\
\text { seu favor }\end{array}$ \\
\hline
\end{tabular}




\begin{tabular}{|c|c|c|c|}
\hline & & $\begin{array}{l}\text { reserva de } \\
\text { alimento durante } \\
\text { o ano para o } \\
\text { período de } \\
\text { hibernação. }\end{array}$ & $\begin{array}{l}\text { mostra a falta } \\
\text { de ética e moral } \\
\text { do personagem. }\end{array}$ \\
\hline $\begin{array}{c}03 \\
10 ' 00 "\end{array}$ & $\begin{array}{l}\text { Devido à fome, Hammy vai atrás das } \\
\text { nozes (1) que havia escondido antes do } \\
\text { inverno e depara-se com um muro de } \\
\text { arbustos, que não estava lá antes da } \\
\text { hibernação e fica muito assustado (2). }\end{array}$ & $\begin{array}{l}\text { (1) A floresta } \\
\text { produz nozes, } \\
\text { alimento } \\
\text { consumido pelos } \\
\text { esquilos. } \\
\text { (2) O muro de } \\
\text { arbustos indica o } \\
\text { impacto do ser } \\
\text { humano no } \\
\text { habitat natural } \\
\text { dos animais da } \\
\text { floresta, } \\
\text { proveniente do } \\
\text { desmatamento. }\end{array}$ & $\begin{array}{l}\text { (2) O ser } \\
\text { humano ocupa c c } \\
\text { espaço dos } \\
\text { animais, } \\
\text { destruindo seu } \\
\text { habitat, } \\
\text { acabando com } \\
\text { seu alimento, } \\
\text { sem a menor } \\
\text { preocupação } \\
\text { com eles. }\end{array}$ \\
\hline $\begin{array}{c}04 \\
10 ' 50 "\end{array}$ & $\begin{array}{l}\text { Hammy volta, conta ao grupo sobre essa } \\
\text { "coisa esquisita” (1) que achou e todos } \\
\text { vão até lá para averiguar. }\end{array}$ & $\begin{array}{l}\text { (1) O arbusto não } \\
\text { é natural para os } \\
\text { animais. } \\
\text { (1) O arbusto } \\
\text { delimita a área de } \\
\text { floresta para os } \\
\text { animais viverem. }\end{array}$ & $\begin{array}{l}\text { (1) O ser } \\
\text { humano } \\
\text { desmata o } \\
\text { habitat dos } \\
\text { animais e } \\
\text { preocupa-se em } \\
\text { afastá-los de } \\
\text { suas casas. }\end{array}$ \\
\hline $\begin{array}{c}05 \\
11 ' 30 \text { ' }\end{array}$ & $\begin{array}{l}\text { Todos ficam espantados (1) e, por não } \\
\text { saberem do que se trata, passam a chamá- } \\
\text { lo de Steve. }\end{array}$ & $\begin{array}{l}\text { (1) } \mathrm{O} \text { arbusto não } \\
\text { é natural para os } \\
\text { animais. }\end{array}$ & \\
\hline $\begin{array}{c}06 \\
13 ' 00 "\end{array}$ & $\begin{array}{l}\text { Verne, o líder do grupo, vai até o outro } \\
\text { lado do muro para descobrir o que há lá } \\
\text { (1). }\end{array}$ & & $\begin{array}{l}\text { (1) } \mathrm{O} \text { grupo de } \\
\text { animais } \\
\text { apresenta um } \\
\text { líder. }\end{array}$ \\
\hline $\begin{array}{c}07 \\
14 ' 20 "\end{array}$ & $\begin{array}{l}\text { Do outro lado da cerca, Verne vive a } \\
\text { maior emoção. Meninos estão jogando } \\
\text { hochey de patins no meio da rua (1) e } \\
\text { fazem-no de bola. Ele é jogado para cima, } \\
\text { para baixo, de um lado para o outro (2). }\end{array}$ & $\begin{array}{l}\text { (1) Atividades de } \\
\text { lazer do ser } \\
\text { humano. }\end{array}$ & $\begin{array}{l}\text { (1) Primeiro } \\
\text { contato dos } \\
\text { animais com o } \\
\text { hábito de vida } \\
\text { dos seres } \\
\text { humanos. } \\
\text { (2) Os seres } \\
\text { humanos não } \\
\text { dão a mínima } \\
\text { importância } \\
\text { para Verne, }\end{array}$ \\
\hline
\end{tabular}




\begin{tabular}{|c|c|c|c|}
\hline & & & $\begin{array}{l}\text { nem o } \\
\text { reconhecem } \\
\text { como animal. }\end{array}$ \\
\hline $\begin{array}{c}08 \\
15 ' 10 "\end{array}$ & $\begin{array}{l}\text { Quando volta, conta o que viu, enquanto } \\
\text { RJ fica observando tudo de cima da } \\
\text { árvore (1). }\end{array}$ & & $\begin{array}{l}\text { (1) RJ observa } \\
\text { com a intenção } \\
\text { de utilizar } \\
\text { aquela situação } \\
\text { a seu favor, para } \\
\text { obter o que } \\
\text { quer. }\end{array}$ \\
\hline $\begin{array}{c}09 \\
15 ' 12 "\end{array}$ & $\begin{array}{l}\text { Todos curiosos perguntam: "O que tinha } \\
\text { do outro lado do muro?" (1) }\end{array}$ & $\begin{array}{l}\text { (1) Os animais } \\
\text { que vivem na } \\
\text { floresta } \\
\text { desconhecem os } \\
\text { seres humanos. }\end{array}$ & \\
\hline $\begin{array}{c}10 \\
15 ' 20 "\end{array}$ & $\begin{array}{l}\text { Verne define os seres humanos como: } \\
\text { "Primatas (1) rosados horrorosos. Devem } \\
\text { ter chegado enquanto hibernávamos (2). } \\
\text { Têm rodas nos pés e bastões (3) e me } \\
\text { bateram como numa brincadeira de mau } \\
\text { gosto." }\end{array}$ & $\begin{array}{l}\text { (1) Os seres } \\
\text { humanos são } \\
\text { classificados } \\
\text { como primatas. } \\
\text { (2) Os seres } \\
\text { humanos não } \\
\text { hibernam. } \\
\text { (3) As } \\
\text { características que } \\
\text { Verne usa para } \\
\text { descrever os seres } \\
\text { humanos mostra } \\
\text { que realmente ele } \\
\text { desconhecia os } \\
\text { humanos. }\end{array}$ & \\
\hline $\begin{array}{c}11 \\
15,25 ’\end{array}$ & $\begin{array}{l}\text { Ozzie dá um conselho a Verne dizendo: } \\
\text { "Devia ter morrido. Devia ter deitado e } \\
\text { morrido." (1) (explicando o que fazer } \\
\text { numa situação de perigo com inimigos. } \\
\text { Porque os sariguês fazem isso.) }\end{array}$ & $\begin{array}{l}\text { (1) Os sariguês, } \\
\text { em situação de } \\
\text { perigo, se fazem } \\
\text { de mortos para } \\
\text { não serem } \\
\text { apanhados. }\end{array}$ & \\
\hline $\begin{array}{c}12 \\
15 ' 28,\end{array}$ & $\begin{array}{l}\text { Verne continua sua explicação: "Não é a } \\
\text { pior parte. Metade da floresta acabou (1). } \\
\text { Os carvalhos e arbustos de frutinhas } \\
\text { simplesmente acabaram!" (2) }\end{array}$ & $\begin{array}{l}\text { (1) A construção } \\
\text { do condomínio } \\
\text { pelos seres } \\
\text { humanos leva ao } \\
\text { desmatamento da } \\
\text { floresta. } \\
\text { (2) O } \\
\text { desmatamento } \\
\text { acaba com a fonte }\end{array}$ & \\
\hline
\end{tabular}




\begin{tabular}{|c|c|c|c|}
\hline & & $\begin{array}{l}\text { de alimentação } \\
\text { dos animais } \\
\text { silvestres. }\end{array}$ & \\
\hline $\begin{array}{c}13 \\
15,40 ”\end{array}$ & $\begin{array}{l}\text { Penny desesperada diz: "Minha nossa!" } \\
\text { (1) }\end{array}$ & & $\begin{array}{l}\text { (1) A } \\
\text { preocupação em } \\
\text { ficar sem } \\
\text { alimento e } \\
\text { passar fome. }\end{array}$ \\
\hline $\begin{array}{c}14 \\
15,42 ”\end{array}$ & $\begin{array}{l}\text { Estela preocupada pergunta: "Como } \\
\text { vamos comer?" (1) }\end{array}$ & $\begin{array}{l}\text { (1) A devastação } \\
\text { da floresta deixa } \\
\text { os animais sem } \\
\text { alimento. }\end{array}$ & $\begin{array}{l}\text { (1) A fome é } \\
\text { uma } \\
\text { preocupação } \\
\text { social. }\end{array}$ \\
\hline $\begin{array}{c}15 \\
15,44,\end{array}$ & $\begin{array}{l}\text { Todos ao mesmo tempo dizem (num } \\
\text { burburinho): "Como vamos viver?" (1) }\end{array}$ & $\begin{array}{l}\text { (1) A alimentação } \\
\text { é o que mantém } \\
\text { os animais vivos. }\end{array}$ & \\
\hline $\begin{array}{c}16 \\
15,47,\end{array}$ & $\begin{array}{l}\text { Verne diz: "Não sei. Só sei de uma coisa. } \\
\text { Estaremos bem desde que ninguém } \\
\text { ultrapasse o Steve (1) (apelido dado pelos } \\
\text { animais ao muro de arbustos) de novo." }\end{array}$ & $\begin{array}{l}\text { (1) Ameaça dos } \\
\text { seres humanos } \\
\text { aos animais } \\
\text { silvestres. }\end{array}$ & $\begin{array}{l}\text { (1) O líder dá } \\
\text { uma ordem, que } \\
\text { deve ser } \\
\text { cumprida por } \\
\text { todos, sem } \\
\text { contestação. }\end{array}$ \\
\hline $\begin{array}{c}17 \\
15,51 ”\end{array}$ & $\begin{array}{l}\text { RJ diz, de cima da árvore, se intrometendo } \\
\text { na conversa: "Isso se chama cerca. E não é } \\
\text { para ser temida, amigo anfíbio (1). É o } \\
\text { portal para a boa vida." (fala com uma luz } \\
\text { iluminando sua cabeça, parecendo } \\
\text { "angelical”)(2) }\end{array}$ & $\begin{array}{l}\text { (1) A tartaruga é } \\
\text { classificada como } \\
\text { anfíbio } \\
\text { (conhecimento } \\
\text { errado). }\end{array}$ & $\begin{array}{l}\text { (2) A aparência } \\
\text { "angelical" } \\
\text { remete aos } \\
\text { padrões morais } \\
\text { de religiosidade, } \\
\text { de santidade, de } \\
\text { parecer bom. }\end{array}$ \\
\hline $\begin{array}{c}18 \\
16^{\prime} 00^{\prime \prime}\end{array}$ & $\begin{array}{l}\text { Verne corrige a fala de } \mathrm{RJ} \text { : "Na verdade, } \\
\text { sou um réptil (1), um erro comum (2). E } \\
\text { você é o..." }\end{array}$ & $\begin{array}{l}\text { (1) Tartaruga é } \\
\text { classificada como } \\
\text { réptil. } \\
\text { (2) Chama } \\
\text { atenção para o } \\
\text { erro comum. }\end{array}$ & \\
\hline $\begin{array}{c}19 \\
16 ' 05 ',\end{array}$ & $\begin{array}{l}\text { RJ desce da árvore e completa: "Que falta } \\
\text { de educação a minha! Sou o RJ. Não pude } \\
\text { evitar de ouvir. Acho que posso dar uma } \\
\text { luz nesse problema de cerca. O que era } \\
\text { antes pura natureza, agora são } 220 \mathrm{~m}^{2} \text { de } \\
\text { paraíso estilizado, produzido pelo homem } \\
\text { (1) (mostra um mapa do condomínio com } \\
\text { a maior parte construída e um pedacinho } \\
\text { de floresta). Exceto esse cantinho aqui. } \\
\text { Vocês estão aqui." (1) (mostra no mapa o } \\
\text { local em que estão com uma lupa, }\end{array}$ & $\begin{array}{l}\text { (1) Os seres } \\
\text { humanos, para } \\
\text { construírem suas } \\
\text { casas, precisaram } \\
\text { destruir o habitat } \\
\text { dos animais. } \\
\text { (2) Desmatamen- } \\
\text { to. }\end{array}$ & \\
\hline
\end{tabular}




\begin{tabular}{|c|c|c|c|}
\hline & querendo dizer que está bem pequeno.) & & \\
\hline $\begin{array}{c}20 \\
16,28,\end{array}$ & Todos espantados: “Ah!" & & \\
\hline $\begin{array}{c}21 \\
160^{\prime}\end{array}$ & $\begin{array}{l}\text { RJ: "Não, isso é bom. Vocês hibernam, } \\
\text { não é? Juntam comida e guardam para o } \\
\text { inverno?" (1) }\end{array}$ & $\begin{array}{l}\text { (1) Para } \\
\text { hibernação os } \\
\text { animais precisam } \\
\text { armazenar } \\
\text { comida. }\end{array}$ & \\
\hline $\begin{array}{c}22 \\
16 ' 32 "\end{array}$ & $\begin{array}{l}\text { Hammy concorda: "Uhu! Enchemos o } \\
\text { tronco!" (1) }\end{array}$ & $\begin{array}{l}\text { (1) Os animais } \\
\text { precisam de muita } \\
\text { comida durante a } \\
\text { hibernação. }\end{array}$ & \\
\hline $\begin{array}{c}23 \\
166^{\prime} 33^{\prime}\end{array}$ & Verne contrariado: "Hammy..." & & \\
\hline $\begin{array}{c}24 \\
16 ’ 34,\end{array}$ & $\begin{array}{l}\text { RJ analisando o tronco pergunta: "É } \\
\text { mesmo? Esse tronco do tamanho de uma } \\
\text { caverna?" }\end{array}$ & & \\
\hline $\begin{array}{c}25 \\
16,37,\end{array}$ & $\begin{array}{l}\text { Ozzie, todo orgulhoso, completa: "Até o } \\
\text { topo!" }\end{array}$ & & \\
\hline $\begin{array}{c}26 \\
16,38,\end{array}$ & Verne indignado: “Ozzie!" & & \\
\hline $\begin{array}{c}27 \\
166^{\prime} 40^{\prime \prime}\end{array}$ & $\begin{array}{l}\text { RJ medindo o tronco: "Quanto tempo } \\
\text { levaram para encher o tronco?" }\end{array}$ & & \\
\hline $\begin{array}{c}28 \\
16 ' 43 \prime\end{array}$ & Heather responde: "274 dias." (1) & $\begin{array}{l}\text { (1) Os animais } \\
\text { levam muito } \\
\text { tempo para juntar } \\
\text { alimento para a } \\
\text { próxima } \\
\text { hibernação. }\end{array}$ & \\
\hline $\begin{array}{c}29 \\
169 \\
6,\end{array}$ & $\begin{array}{l}\text { RJ instigando os animais pergunta:" Já } \\
\text { fizeram em uma semana?" }\end{array}$ & & \\
\hline $\begin{array}{c}30 \\
16 ' 47^{\prime \prime}\end{array}$ & Verne responde: "Isso é impossível!" (1) & $\begin{array}{l}\text { (1) O trabalho de } \\
\text { juntar alimento é } \\
\text { uma tarefa árdua } \\
\text { e demorada. }\end{array}$ & \\
\hline $\begin{array}{c}31 \\
16 ' 48,\end{array}$ & $\begin{array}{l}\text { RJ rebate a afirmação dizendo: "Não se } \\
\text { trabalharmos juntos! Vejam, vocês têm a } \\
\text { habilidade, eu tenho o "know-how" (1) e } \\
\text { eles têm a comida." (2) (apontando para } \\
\text { o outro lado do muro) }\end{array}$ & $\begin{array}{l}\text { (2) Os seres } \\
\text { humanos têm } \\
\text { grande } \\
\text { disponibilidade } \\
\text { de alimento. } \\
\text { (2) Os animais } \\
\text { silvestres se } \\
\text { alimentam dos } \\
\text { alimentos dos } \\
\text { seres humanos. }\end{array}$ & $\begin{array}{l}\text { (1) A } \\
\text { importância do } \\
\text { trabalho em } \\
\text { grupo, em que } \\
\text { cada um } \\
\text { contribui com } \\
\text { as qualidades } \\
\text { que tem. }\end{array}$ \\
\hline
\end{tabular}




\begin{tabular}{|c|c|c|c|}
\hline $\begin{array}{c}32 \\
16,54,\end{array}$ & $\begin{array}{l}\text { Heather curiosa pergunta: "Quanta } \\
\text { comida?" }\end{array}$ & & \\
\hline $\begin{array}{c}33 \\
16 ' 56 "\end{array}$ & $\begin{array}{l}\text { RJ utiliza uma expressão popular para } \\
\text { responder: "Saindo pelo ladrão!" (1) }\end{array}$ & $\begin{array}{l}\text { (1) Os seres } \\
\text { humanos têm } \\
\text { grande } \\
\text { disponibilidade } \\
\text { de alimento. }\end{array}$ & \\
\hline $\begin{array}{c}34 \\
17^{\prime} 00^{\prime \prime}\end{array}$ & $\begin{array}{l}\text { Verne, desconfiado, diz: "Não estamos } \\
\text { interessados em nada que venha de } \\
\text { ladrão" (1) }\end{array}$ & & $\begin{array}{l}\text { (1) O termo } \\
\text { "ladrão", sendo } \\
\text { usado no } \\
\text { sentido literal, } \\
\text { não é algo bom, } \\
\text { mas, no sentido } \\
\text { figurado, usado } \\
\text { por RJ, pode ser } \\
\text { positivo. }\end{array}$ \\
\hline $\begin{array}{c}35 \\
177^{\prime} 03,\end{array}$ & $\begin{array}{l}\text { Lou tentando convencer os outros: "Eu } \\
\text { não sei, faz sentido o que ele diz. } \\
\text { Devemos ouví-lo." }\end{array}$ & & \\
\hline $\begin{array}{c}36 \\
17^{\prime} 07^{\prime \prime}\end{array}$ & $\begin{array}{l}\text { Penny, entusiasmada, diz: "Sim, eu aceito } \\
\text { comida de ladrão." (1) }\end{array}$ & $\begin{array}{l}\text { (1) Os animais } \\
\text { podem se } \\
\text { alimentar das } \\
\text { mesmas comidas } \\
\text { que os seres } \\
\text { humanos. }\end{array}$ & \\
\hline $\begin{array}{c}37 \\
17 ' 11 "\end{array}$ & $\begin{array}{l}\text { Verne, desconfiado: "Não aceita, não. } A \\
\text { cauda está tremendo!" (1) }\end{array}$ & & $\begin{array}{l}\text { (1) Desconfiar } \\
\text { de algo novo. O } \\
\text { líder preocupa- } \\
\text { se com o bem- } \\
\text { estar do grupo. } \\
\text { (1) A cauda } \\
\text { tremendo é um } \\
\text { elemento } \\
\text { figurado para a } \\
\text { desconfiança do } \\
\text { líder. }\end{array}$ \\
\hline $\begin{array}{c}38 \\
17 ' 12,\end{array}$ & Todos se espantam: “Oh!” (1) & & $\begin{array}{l}\text { (1) Quando o } \\
\text { líder desconfia, } \\
\text { todos ficam } \\
\text { preocupados. }\end{array}$ \\
\hline $\begin{array}{c}39 \\
17 ' 14,\end{array}$ & $\begin{array}{l}\text { RJ pergunta sem entender nada: "Espere! } \\
\text { O que está o quê?" }\end{array}$ & & \\
\hline $\begin{array}{c}40 \\
17 ' 16 "\end{array}$ & $\begin{array}{l}\text { Verne explica a RJ: "Quando algo parece } \\
\text { errado a minha cauda treme (1). E deixa } \\
\text { eu te contar uma coisa, tudo o que você }\end{array}$ & & $\begin{array}{l}\text { (1) A } \\
\text { importância do } \\
\text { líder se }\end{array}$ \\
\hline
\end{tabular}




\begin{tabular}{|c|c|c|c|}
\hline & disse está me "balançando"!" & & $\begin{array}{l}\text { preocupar com } \\
\text { o grupo e } \\
\text { desconfiar de } \\
\text { alguma situação } \\
\text { inusitada. }\end{array}$ \\
\hline $\begin{array}{c}41 \\
17 ' 22,\end{array}$ & $\begin{array}{l}\text { RJ tentando tranquilizar Verne diz: "É } \\
\text { Verne, certo? Não há porque ter medo." }\end{array}$ & & \\
\hline $\begin{array}{c}42 \\
17 ' 28 ”\end{array}$ & $\begin{array}{l}\text { Verne, decidido, diz: "É, mas eu tenho. E } \\
\text { por uma boa razão." (aponta para a } \\
\text { cauda) (1) }\end{array}$ & & $\begin{array}{l}\text { (1) O líder é } \\
\text { quem toma as } \\
\text { decisões por } \\
\text { todos, seguindo } \\
\text { sua intuição. }\end{array}$ \\
\hline $\begin{array}{c}43 \\
17 ’ 29 ”\end{array}$ & Todos espantados: “Oh!” & & \\
\hline $\begin{array}{c}44 \\
17 \text { '30', }\end{array}$ & $\begin{array}{l}\text { Verne completa: "Não é uma marca de } \\
\text { nascença." }\end{array}$ & & \\
\hline $\begin{array}{c}45 \\
17 ’ 35 "\end{array}$ & $\begin{array}{l}\text { RJ escovando o casco de Verne com uma } \\
\text { escova de dente elétrica que trouxe do } \\
\text { "mundo dos humanos" diz: "Foi porque } \\
\text { você não teve um bom guia." }\end{array}$ & & \\
\hline $\begin{array}{c}46 \\
17 ’ 37 ’\end{array}$ & $\begin{array}{l}\text { Verne decidido diz: "Tudo bem, mas não } \\
\text { estamos interessados.” (1) }\end{array}$ & & $\begin{array}{l}\text { (1) O líder é } \\
\text { quem toma as } \\
\text { decisões pelo } \\
\text { grupo. }\end{array}$ \\
\hline $\begin{array}{c}47 \\
17 ’ 38 ’\end{array}$ & $\begin{array}{l}\text { RJ instiga Verne: "Não está interessado } \\
\text { na comida mais deliciosa que já provou?" } \\
\text { (1) }\end{array}$ & $\begin{array}{l}\text { (1) A comida dos } \\
\text { seres humanos é } \\
\text { muito saborosa } \\
\text { para todos os } \\
\text { animais. }\end{array}$ & \\
\hline $\begin{array}{c}48 \\
177^{\prime} 40^{\prime \prime}\end{array}$ & $\begin{array}{l}\text { Verne afirma: "Não! Não estou } \\
\text { interessado!” (1) }\end{array}$ & & $\begin{array}{l}\text { (1) O líder é } \\
\text { quem toma as } \\
\text { decisões por } \\
\text { todos. }\end{array}$ \\
\hline $\begin{array}{c}49 \\
17 ' 45,\end{array}$ & $\begin{array}{l}\text { RJ completa dizendo: "Tudo bem. } \\
\text { Entendo você não está aberto para isso." }\end{array}$ & & \\
\hline $\begin{array}{c}50 \\
177^{\prime} 50 "\end{array}$ & $\begin{array}{l}\text { RJ abre um pacote de salgadinho, } \\
\text { espalhando farelo em todos os animais, } \\
\text { como se fosse um pó mágico. } \\
\text { Nesse momento, mostra o globo terrestre } \\
\text { de fora e uma explosão de farelos em um } \\
\text { ponto do planeta, parecendo a explosão } \\
\text { de uma bomba atômica. }\end{array}$ & $\begin{array}{l}\text { (1) Explosão de } \\
\text { uma bomba } \\
\text { atômica vista de } \\
\text { fora do planeta } \\
\text { Terra. }\end{array}$ & \\
\hline $\begin{array}{c}51 \\
18,00 "\end{array}$ & $\begin{array}{l}\text { Todos tontos e extasiados: "Minha } \\
\text { nossa!" (1) }\end{array}$ & $\begin{array}{l}\text { (1) O salgadinho } \\
\text { tem substâncias } \\
\text { mágicas (altera o }\end{array}$ & \\
\hline
\end{tabular}




\begin{tabular}{|c|c|c|c|}
\hline & & $\begin{array}{l}\text { estado } \\
\text { emocional). }\end{array}$ & \\
\hline $\begin{array}{c}52 \\
18 ' 10,\end{array}$ & $\begin{array}{l}\text { Hammy completamente alucinado: "O } \\
\text { que é isso?"(1) }\end{array}$ & $\begin{array}{l}\text { (1) O salgadinho } \\
\text { tem substâncias } \\
\text { mágicas. }\end{array}$ & \\
\hline $\begin{array}{l}53 \\
18 ' 12,\end{array}$ & $\begin{array}{l}\text { RJ dá uma explicação sobre o salgadinho: } \\
\text { "Amigo, é uma combinação mágica de } \\
\text { farinha de milho, queijo desidratado, } \\
\text { BHA, BHT e o velho e bom MSG, também } \\
\text { conhecido por salgadinho. Nacho sabor } \\
\text { queijo.” (1) }\end{array}$ & $\begin{array}{l}\text { (1) O salgadinho } \\
\text { contém farinha de } \\
\text { milho, queijo } \\
\text { desidratado, } \\
\text { BHA, BHT e } \\
\text { MSG, que são } \\
\text { diferentes } \\
\text { substâncias } \\
\text { químicas. }\end{array}$ & \\
\hline $\begin{array}{l}54 \\
18 ' 22 "\end{array}$ & $\begin{array}{l}\text { Hammy, completamente "viciado": Mais, } \\
\text { por favor! Mais! (1) }\end{array}$ & $\begin{array}{l}\text { (1) Os } \\
\text { salgadinhos } \\
\text { podem tornar as } \\
\text { pessoas } \\
\text { dependentes. }\end{array}$ & \\
\hline $\begin{array}{c}55 \\
188^{\prime} 23 ”\end{array}$ & $\begin{array}{l}\text { Estela concorda com Hammy: "Sim, } \\
\text { Verne, isso é bom." (1) }\end{array}$ & & $\begin{array}{l}\text { (1) O líder é } \\
\text { questionado } \\
\text { para dar sua } \\
\text { aprovação. }\end{array}$ \\
\hline $\begin{array}{c}56 \\
18 ' 26 "\end{array}$ & $\begin{array}{l}\text { RJ concorda com Estela e completa } \\
\text { dizendo: "É tudo bom. E nós vamos até lá } \\
\text { hoje à noite." (1) }\end{array}$ & $\begin{array}{l}\text { (1) Os animais } \\
\text { invadem as casas } \\
\text { dos seres } \\
\text { humanos para } \\
\text { buscar alimento. } \\
\text { Animais silvestres } \\
\text { como pragas, } \\
\text { devido à falta de } \\
\text { alimento em seu } \\
\text { habitat. }\end{array}$ & \\
\hline $\begin{array}{c}57 \\
18 ' 28\end{array}$ & $\begin{array}{l}\text { Termina a cena com RJ jogando } \\
\text { salgadinhos para cima. }\end{array}$ & & \\
\hline
\end{tabular}

Cena 3

\begin{tabular}{|c|c|c|c|}
\hline $\begin{array}{c}\text { Trechos } \\
\text { das } \\
\text { cenas }\end{array}$ & $\begin{array}{c}\text { Transcrição de algumas falas e descrição } \\
\text { das cenas do filme }\end{array}$ & $\begin{array}{c}\text { Conceitos } \\
\text { científicos } \\
\text { contidos nas } \\
\text { cenas }\end{array}$ & $\begin{array}{c}\text { Padrões morais } \\
\text { e valores } \\
\text { contidos nas } \\
\text { cenas }\end{array}$ \\
\hline $\mathbf{0 1}$ & $\begin{array}{l}\text { À noite, todos vão até o condomínio (1), } \\
\text { ficam maravilhados com tudo. }\end{array}$ & $\begin{array}{l}\text { (1) Os animais } \\
\text { são vistos como }\end{array}$ & \\
\hline
\end{tabular}




\begin{tabular}{|c|c|c|c|}
\hline 18'30"' & & $\begin{array}{l}\text { pragas e invadem } \\
\text { as casas dos seres } \\
\text { humanos. }\end{array}$ & \\
\hline $\begin{array}{c}02 \\
19,56,\end{array}$ & $\begin{array}{l}\text { Uma mulher entra com uma caixa cheia de } \\
\text { compras do supermercado. } \\
\text { RJ diz: A comida estava na caixa. }\end{array}$ & & \\
\hline $\begin{array}{c}03 \\
20 ’ 01\end{array}$ & $\begin{array}{l}\text { Verne está com muito medo e diz: } \\
\text { "Podemos pegar a comida (1) e ir embora } \\
\text { logo?" }\end{array}$ & $\begin{array}{l}\text { (1) Os animais } \\
\text { pegam a comida } \\
\text { dos seres } \\
\text { humanos. } \\
\text { (1) Animais são } \\
\text { caracterizados } \\
\text { como pragas ao } \\
\text { invadirem as } \\
\text { casas dos seres } \\
\text { humanos. }\end{array}$ & \\
\hline $\begin{array}{c}04 \\
\text { 20'08', }\end{array}$ & $\begin{array}{l}\text { RJ conclui sobre o hábito de vida dos } \\
\text { seres humanos em comparação com o dos } \\
\text { animais: "Nós comemos para viver, eles } \\
\text { vivem para comer! (1) Vou mostrar para } \\
\text { vocês." }\end{array}$ & $\begin{array}{l}\text { (1) Explica a } \\
\text { relação de } \\
\text { alimentação dos } \\
\text { seres humanos e } \\
\text { dos animais. } \\
\text { Os seres humanos } \\
\text { comem mais do } \\
\text { que precisam, } \\
\text { enquanto os } \\
\text { animais apenas o } \\
\text { necessário. }\end{array}$ & \\
\hline $\begin{array}{c}05 \\
20 ' 15,\end{array}$ & $\begin{array}{l}\text { RJ completa: “A boca humana é um } \\
\text { buraco sem fundo.” (imagem de um } \\
\text { humano comendo hambúrguer) (1) }\end{array}$ & $\begin{array}{l}\text { (1) A alimentação } \\
\text { é feita pela boca. }\end{array}$ & \\
\hline $\begin{array}{c}06 \\
20 ' 20 ”\end{array}$ & $\begin{array}{l}\text { RJ diz: "O homem também é um "saco de } \\
\text { batata"." (humano sentando no sofá em } \\
\text { frente à TV) (1) }\end{array}$ & $\begin{array}{l}\text { (1) O ser humano } \\
\text { come mais do que } \\
\text { precisa. }\end{array}$ & $\begin{array}{l}\text { (1) A gula é um } \\
\text { grave defeito } \\
\text { dos seres } \\
\text { humanos, por } \\
\text { isso há } \\
\text { problemas de } \\
\text { obesidade. }\end{array}$ \\
\hline $\begin{array}{c}07 \\
\text { 20'22" }\end{array}$ & $\begin{array}{l}\text { RJ indicando o telefone que está tocando: } \\
\text { Isso é um sinal para buscar comida. }\end{array}$ & & \\
\hline $\begin{array}{c}08 \\
20 \prime 23 "\end{array}$ & $\begin{array}{l}\text { Toca a campainha e RJ diz: "Essa é uma } \\
\text { das vozes da comida." }\end{array}$ & & \\
\hline $\begin{array}{c}09 \\
20 ' 27,\end{array}$ & $\begin{array}{l}\text { Mostra a porta e RJ diz: "Esse é o portal } \\
\text { para passar a comida." }\end{array}$ & & \\
\hline $\begin{array}{c}10 \\
20 ' 30 "\end{array}$ & $\begin{array}{l}\text { Mostra a motocicleta e RJ explica: "Esse é } \\
\text { um dos muitos veículos que transportam }\end{array}$ & & \\
\hline
\end{tabular}




\begin{tabular}{|c|c|c|c|}
\hline & comida." & & \\
\hline $\begin{array}{c}11 \\
20 ' 34 ”\end{array}$ & $\begin{array}{l}\text { Passam caminhões de transporte de } \\
\text { alimento e vans de lanchonetes e RJ } \\
\text { explica: "Os humanos trazem, pegam, } \\
\text { mandam e dirigem a comida." }\end{array}$ & & \\
\hline $\begin{array}{c}12 \\
20 ’ 38,\end{array}$ & $\begin{array}{l}\text { Mostra propaganda de pessoas vestidas de } \\
\text { sorvetes e RJ completa: "Eles vestem a } \\
\text { comida." }\end{array}$ & & \\
\hline $\begin{array}{c}13 \\
20 ' 40 ”\end{array}$ & $\begin{array}{l}\text { Mostra uma chapa com linguiça e RJ } \\
\text { explica: "Isso deixa a comida quente." }\end{array}$ & & \\
\hline $\begin{array}{c}14 \\
20 ’ 40 ”\end{array}$ & $\begin{array}{l}\text { Mostra um isopor com gelo e refrigerantes } \\
\text { e RJ explica: "Isso esfria." }\end{array}$ & & \\
\hline $\begin{array}{c}15 \\
20,49\end{array}$ & $\begin{array}{l}\text { Mostra a mesa de jantar com pessoas } \\
\text { sentadas, rezando e RJ explica: "Esse é o } \\
\text { altar onde eles adoram a comida." }\end{array}$ & & \\
\hline $\begin{array}{c}16 \\
20 ' 53 "\end{array}$ & $\begin{array}{l}\text { Mostra propaganda de TV passando } \\
\text { imagem de um copo d'água com dois } \\
\text { comprimidos efervescentes e RJ diz: “Eles } \\
\text { comem isso quando comem muito.” (1) }\end{array}$ & $\begin{array}{l}\text { (1) Comprimidos } \\
\text { efervescentes são } \\
\text { bons para } \\
\text { melhorar a } \\
\text { digestão. }\end{array}$ & \\
\hline $\begin{array}{c}17 \\
20,55,\end{array}$ & $\begin{array}{l}\text { Mostra uma pessoa fazendo exercícios em } \\
\text { um transfer e RJ completa: "Isso deixa } \\
\text { eles comerem mais comida." (1) }\end{array}$ & $\begin{array}{l}\text { (1) Exercícios } \\
\text { físicos são } \\
\text { indicados para } \\
\text { emagrecer. }\end{array}$ & \\
\hline $\begin{array}{c}18 \\
21 ' 03,\end{array}$ & $\begin{array}{l}\text { RJ, então, pergunta para todos os animais: } \\
\text { "Vocês pensam que eles têm o } \\
\text { suficiente?" }\end{array}$ & & \\
\hline $\begin{array}{c}19 \\
21 ' 04 "\end{array}$ & $\begin{array}{l}\text { Todos os animais fazem sinal de sim com } \\
\text { a cabeça, acreditando que os humanos têm } \\
\text { tudo o que precisam (1). }\end{array}$ & & $\begin{array}{l}\text { (1) O } \\
\text { importante é ter } \\
\text { o suficiente para } \\
\text { viver bem, não } \\
\text { é necessário ter } \\
\text { cada vez mais. }\end{array}$ \\
\hline $\begin{array}{c}20 \\
21 ' 06 "\end{array}$ & $\begin{array}{l}\text { RJ completa: "Não, eles não têm tudo. } \\
\text { Para os humanos, é impossível comer um } \\
\text { só.” (1) }\end{array}$ & $\begin{array}{l}\text { (1) Os seres } \\
\text { humanos comem } \\
\text { mais do que } \\
\text { precisam. }\end{array}$ & $\begin{array}{l}\text { (1) A falta de } \\
\text { limite mostra } \\
\text { que os humanos } \\
\text { nunca estão } \\
\text { satisfeitos com } \\
\text { o que eles têm, } \\
\text { sempre querem } \\
\text { mais. }\end{array}$ \\
\hline $\begin{array}{c}21 \\
21 ' 09 "\end{array}$ & Todos se assustam: “Oh!” (1) & $\begin{array}{l}\text { (1) Os animais } \\
\text { comem apenas o } \\
\text { necessário. }\end{array}$ & \\
\hline 22 & RJ pergunta a todos para concluir sua & (1) Todos os & \\
\hline
\end{tabular}




\begin{tabular}{|c|c|c|c|}
\hline 21'11" & $\begin{array}{l}\text { explicação: “O que eles fazem com o que } \\
\text { não comem? Colocam em latas prateadas } \\
\text { brilhantes. Só para nós." (1) }\end{array}$ & $\begin{array}{l}\text { restos de alimento } \\
\text { dos seres } \\
\text { humanos são } \\
\text { jogados no lixo. } \\
\text { (1) Os animais } \\
\text { reviram o lixo dos } \\
\text { seres humanos } \\
\text { atrás de comida. }\end{array}$ & \\
\hline $\begin{array}{c}23 \\
22 ' 05 \text { ' }\end{array}$ & $\begin{array}{l}\text { Neste momento, a mulher abre a porta de } \\
\text { casa, se assusta com os animais, pega } \\
\text { uma vassoura e corre atrás deles para } \\
\text { matá-los (1). }\end{array}$ & $\begin{array}{l}\text { (1) Os animais } \\
\text { são vistos como } \\
\text { pragas pelos seres } \\
\text { humanos. }\end{array}$ & \\
\hline $\begin{array}{c}24 \\
22 ' 15,\end{array}$ & $\begin{array}{l}\text { Todos os animais voltam assustados para } \\
\text { a floresta e não querem mais pegar comida } \\
\text { nas casas dos humanos. }\end{array}$ & & \\
\hline $\begin{array}{c}25 \\
25,45,\end{array}$ & $\begin{array}{l}\text { RJ inventa uma mentira, dizendo que sua } \\
\text { família foi morta por um cortador de } \\
\text { gramas, deixando todos com pena dele. } \\
\text { Dessa forma, tenta convencê-los de pegar } \\
\text { comida novamente, para se livrar de } \\
\text { Vincent (1). Seu plano dá certo. }\end{array}$ & & $\begin{array}{l}\text { (1) Valor da } \\
\text { família. } \\
\text { (1) Importância } \\
\text { de ajudar quem } \\
\text { está com } \\
\text { maiores } \\
\text { dificuldades. }\end{array}$ \\
\hline
\end{tabular}

\subsection{Análise do discurso do filme trabalhado}

A análise do discurso do filme "OS SEM FLORESTA" busca perceber as mensagens que estão por dentro de seu discurso, o que permite um outro olhar sobre esse recurso, que é muitas vezes utilizado em sala de aula, principalmente em aulas de ciências. Acredito que essa visão crítica terá uma grande contribuição e será de extrema importância na análise dos dados da pesquisa.

Analisar o filme a partir de seu discurso é uma tarefa árdua porque devo levar em conta as mensagens faladas e as mensagens inseridas em cada cena, que são as imagens a partir de gestos e símbolos dos personagens e do contexto em que estão inseridos.

De acordo com Gregolin (2003), a análise do discurso propõe descrever as articulações entre a materialidade dos enunciados, seu agrupamento em discursos, sua inserção em formações discursivas, sua circulação através de práticas, seu controle por princípios relacionados ao poder e sua inscrição em um arquivo histórico. A partir dessa 
definição, pretendo trabalhar essa análise do discurso de um ponto de vista crítico, mergulhando nos enunciados que o filme se propõe a transmitir.

Acredito que o enredo do filme tenha uma intenção comunicativa, como proposto por Dooley (2003):

"As pessoas não contam histórias (ou falam) simplesmente por falar. Elas estão oferecendo algo, de natureza interacional, que faz algo, como descrever ou explicar ou dar conta, de algum modo, das circunstâncias atuais. A intenção comunicativa pode ser uma combinação de diversas intenções, geralmente dispostas em camadas."

De acordo com Fischer (2001), os discursos não podem ser vistos de forma compacta, como se houvesse uma totalidade bem-acabada, eles devem ser vistos a partir dos diferentes momentos de enunciação e devem ser analisados criticamente como objetos vivos porque não é possível separar a interação dos discursos (interdiscursividade) do funcionamento intradiscursivo, isto é, da dinâmica dos enunciados dentro da mesma formação. Deve-se deixar aflorar a heterogeneidade que está presente em todo o discurso. A autora utiliza as investigações sobre a mídia (nos seriados de TV, entrevistas, reportagens, documentários, clips, debates ao vivo, cartas e peças publicitárias) e a educação para exemplificar a teoria de Foucault e caracterizar o discurso da mídia como um discurso marcado pela heterogeneidade definidora da formação discursiva em que se insere. Ela conclui que, a partir de Foucault, um determinado objeto existe sob condições "positivas", na dinâmica de um feixe de relações, e que há condições de aparecimento histórico de um determinado discurso, relativas às formações não discursivas (instituições, processos sociais e econômicos). Essas relações podem ser aprendidas e descritas a partir dos próprios textos que se pretendem analisar; a partir deles, é possível destacar as regras pelas quais o jogo de relações entre o discursivo e o não discursivo, em uma determinada época, fazem aparecer aquele objeto, e não outro, como objeto de poder e saber.

Nesse contexto, insere-se esse projeto, em que apresento uma visão do discurso do filme pela sua totalidade e pelas suas partes para definir as mensagens que esse recurso se propõe a passar, analisando o que há por trás dessa produção de sentidos e significados inserida em um contexto sócio-cultural bombardeado de informações por todos os lados. 


\subsubsection{Apresentação do dado}

Analiso o discurso de um filme de animação infanto-juvenil amplamente divulgado pela mídia, cujo nome é "OS SEM FLORESTA".

Inicialmente, faço a descrição dos dados para contextualizar o filme. Selecionei as três primeiras cenas do filme, por acreditar que tais cenas são o foco central do filme e têm como objetivo reproduzir um discurso que está enraizado em nosso dia-a-dia. Já percebo, porém, que o filme apresenta diversas posições sobre os assuntos abordados, o que será discutido posteriormente.

Enumero as situações antes de cada fragmento da transcrição e descrição das cenas, para facilitar a discussão e identifico os nomes dos personagens ao animal que representam no filme, reproduzindo fielmente como citado neste.

\subsubsection{Descrição do dado}

O filme se passa em um fragmento de floresta remanescente da construção de um condomínio, em que as personagens principais são animais nativos que, após o período de hibernação, quando começa a primavera, encontram-se sem alimento, devido à destruição de seu habitat natural.

Assim, o "bandido" da história, RJ, utiliza-se dessa situação para resolver seu problema com o urso Vincent, porque RJ roubou as reservas alimentares de Vincent, então, o urso deu o prazo de uma semana para que RJ recuperasse tudo que lhe fora tomado. Dessa forma, RJ junta-se ao grupo de animais que estão sem alimento e os convence a buscarem comida nas casas dos seres humanos, que ficam no condomínio construído. Todos, a princípio, ficam muito amedrontados mas, depois de serem apresentados ao salgadinho de RJ que, no filme, parece ter poderes "mágicos", decidem se aventurar para buscar mais comida.

O filme apresenta algumas problemáticas atuais, porém não discute, de maneira crítica, nenhuma delas, deixando o observador decidir que posição deseja escolher, tentando ser bem "democrático" e agradável aos espectadores. 


\subsubsection{Análise do discurso}

“...[não há] enunciado livre, neutro e independente; mas sempre um enunciado fazendo parte de uma série ou de um conjunto, desempenhando um papel no meio dos outros, neles se apoiando e deles se distinguindo: ele se integra sempre em um jogo enunciativo, onde tem sua participação, por ligeira e ínfima que seja. [...] Não há enunciado que não suponha outros; não há nenhum que não tenha, em torno de si, um campo de coexistências." (FOUCAULT, 1986, p.114)

Ao se fazer a análise do discurso de um determinado material, como é o caso do filme aqui analisado, deve-se multiplicar as relações dos significados, ou seja, deve-se situar as "coisas ditas" em campos discursivos, extrair delas alguns enunciados e colocá-los em relação a outros, do mesmo campo ou de campos distintos (FISCHER, 2001).

Para trabalhar a análise do discurso desse filme, utilizei duas questões principais: a primeira tentando contextualizar em que local esse discurso está inserido como, por exemplo, a posição da mídia, da sociedade capitalista e dos ambientalistas e, a segunda, analisar o que está dentro desse discurso, o que ele quer realmente dizer com tudo isso.

Acredito que, por se tratar de um filme de ampla divulgação e ser destinado ao público infantil, suas mensagens apresentam-se, de maneira geral, ambíguas, não adotando opiniões sobre assuntos polêmicos, tais como a destruição das florestas, extinção de animais, obesidade e consumismo exagerado. Dessa forma, o objetivo principal da produtora é fazer um filme agradável, que não entre em choque com nenhuma opinião em particular. Assim, o filme está calcado em uma opinião já estabelecida, fazendo o produto para vender a todos os públicos, um discurso para todos.

Porém, como tratado por Koch (1987), todo discurso é uma ação verbal e como qual é dotada de intencionalidade. $\mathrm{O}$ ato de argumentar, isto é, de orientar o discurso no sentido de determinadas conclusões, constitui o ato linguístico fundamental, pois a todo e qualquer discurso subjaz uma ideologia. O autor afirma que a neutralidade é apenas um mito, que o discurso que se pretende neutro, ingênuo, contém uma ideologia, que é a da sua própria objetividade.

Ao analisar o filme, percebo a intencionalidade de se manter neutro e, ao mesmo tempo, "discutir" os assuntos mais enfocados nos dias de hoje sem tomar uma posição 
concreta sobre qualquer um deles. A neutralidade atribuída ao filme se dá por meio das mensagens já bem estabelecidas e discutidas pela sociedade, sem um viés de crítica, de posicionamento dos produtores do filme, concordo com o que afirma Koch (1987):

"O estilo neutro deve também ser considerado como um caso particular de renúncia, que se destina a aumentar a credibilidade, por contraste a um estilo argumentativo mais inflamado."

Assim, ao compreender um enunciado, estarei apreendendo essas intenções que estão imersas no discurso. Os sentidos dos enunciados se estabelecem entre os interlocutores num jogo de representações que pode corresponder ou não a uma realidade psicológica ou social (Koch, 1987).

\subsubsection{Em que discursos o filme se assenta?}

O primeiro discurso que fica evidente é o discurso dos ambientalistas que são contra as construções que destroem as florestas, reduzindo as áreas disponíveis para os animais silvestres procurarem e obterem comida e abrigo. Porém, ao mesmo tempo, o filme mostra uma solução para o problema acima, quando os animais são apresentados à comida dos humanos, como citado nos trechos 47, 50, 51 e 52 da cena 2: "Não está interessado na comida mais deliciosa que já provou?", "RJ abre um pacote de salgadinho, espalhando farelo em todos, como se fosse um pó mágico. Nesse momento, mostra o globo terrestre de fora e uma explosão de farelos em um ponto do planeta, parecendo a explosão de uma bomba atômica", "Todos tontos e extasiados: Minha nossa!" e "Hammy completamente aluncinado: O que é isso?".

O filme faz alusão ao discurso científico dando nomes técnicos aos ingredientes dos salgadinhos, como mostrado no trecho 53 da cena 2: “Amigo, é uma combinação mágica de farinha de milho, queijo desidratado, BHA, BHT e o velho e bom MSG, também conhecido por salgadinho. Nacho sabor queijo.", querendo demonstrar que a Ciência está inserida ali, consequentemente, não deve fazer mal à saúde. O discurso da Ciência legitima o consumo do salgadinho. 
Também é abordado o tema do consumismo exagerado do ser humano na cena 3 , dos trechos 04 a 20: "Nós comemos para viver, eles vivem para comer! Vou mostrar para vocês.", "A boca humana é um buraco sem fundo (imagem de um humano comendo hambúrguer).", "O homem também é um "saco de batata” (humano sentando no sofá em frente à TV).", "Indicando o telefone: Isso é um sinal para buscar comida.", "Toca a campainha: Essa é uma das vozes da comida.", "Mostra a porta: Esse é o portal para passar a comida.", "Mostra a motocicleta: Esse é um dos muitos veículos que transportam comida.", "Passam caminhões de transporte de alimento, vans de lanchonetes: Os humanos trazem, pegam, mandam e dirigem a comida.", "Mostra propaganda de pessoas vestidas de sorvetes: Eles vestem a comida.", "Mostra uma chapa com linguiça: Isso deixa a comida quente.", "Mostra um isopor com gelo e refrigerantes: Isso esfria.", "Mostra a mesa de jantar com pessoas sentadas e rezando: Esse é o altar onde eles adoram a comida.", “Mostra propaganda de TV passando imagem de um copo d'água com dois comprimidos efervescentes: Eles comem isso quando comem muito.", "Mostra uma pessoa fazendo exercícios em um transfer: Isso deixa eles comerem mais comida.", "Vocês pensam que eles têm o suficiente?", "Todos fazem sinal de sim com a cabeça.", "Não, eles não têm tudo. Para os humanos, é impossível comer um só." e "Todos se assustam: Oh!".

Ao mesmo tempo em que aborda "problemas" relacionados ao grande consumismo, como obesidade e má digestão, aponta soluções práticas e viáveis (comprimidos efervescentes, esteiras para perder peso), atingindo todos os públicos, sem criticar nenhuma posição. Fazendo-se democrático e neutro, uma neutralidade objetivada para atender a todas as demandas da sociedade, sem fazer críticas a qualquer posicionamento.

Há também o discurso dos animais como pragas naturais que atormentam os moradores do condomínio, que veem aqueles animais como vetores de doenças e falta de higiene porque eles reviram o lixo, deixando o condomínio uma verdadeira bagunça. Mas, ao mesmo tempo, humaniza esses animais, o que faz o espectador "sentí-los" como parte de seu meio, fazendo-os interiorizar, mais uma vez, a ideia dos ambientalistas, de que deve-se proteger os animais, mostrando a justificativa pela qual eles "invadem" nossos espaços porque, antes deles fazerem isso, nós o fizemos no habitat deles.

O filme aborda o tema do individualismo versus a família, mostrando que RJ, o "vilão" da história, quer usar seus supostos amigos para conseguir se livrar de um grande 
problema. Ele não tem a preocupação com o próximo, apenas consigo mesmo porém, no final do filme, ele se arrepende de tudo e ajuda seus amigos a se livrarem da exterminação pelo especialista em destruir pragas.

Esses discursos são apenas simulações de posições críticas, há a exposição de todas, apenas porque a sociedade trata todas elas de alguma forma, porém não convoca para uma reflexão crítica do espectador, que apenas observa tudo sem sentir desconforto com nenhuma situação abordada. O objetivo do filme é divertir, passar o tempo, não foi feito para uma reflexão mais aprofundada sobre algum dos temas "polêmicos" que o filme comenta.

\subsubsection{O que há por dentro desses discursos?}

Percebo, primeiramente, o discurso dos ambientalistas que têm a preocupação com o crescimento sustentável para preservar o meio ambiente, protegendo a fauna e a flora dos ecossistemas, mostrando o problema pelo ponto de vista dos animais humanizados. Um discurso de que não devemos destruir os habitat naturais dos animais pois, dessa forma, podemos levar muitas espécies à extinção, caso elas não se adaptem a nova forma de vida a que são expostas. Por dentro desse discurso está a voz das instituições que defendem o meio ambiente, criticando o papel dos seres humanos como destruidores de seu próprio habitat.

Há um discurso muito marcado que é o da indústria de salgadinhos coloridos e aromatizados artificialmente, ao mesmo tempo em que mostra, mesmo de forma sutil, que esse tipo de alimento "vicia" aqueles que o consomem, como demonstrado na cena 2 nos trechos 50, 51, 52 e 54 ("RJ abre um pacote de salgadinho, espalhando farelo em todos, como se fosse um pó mágico. Nesse momento, mostra o globo terrestre de fora e uma explosão de farelos em um ponto do planeta, parecendo a explosão de uma bomba atômica.", "Todos tontos e extasiados: Minha nossa!", "Hammy completamente aluncinado: O que é isso?" e "Hammy: Mais, por favor! Mais!"), também mostra que esses salgadinhos podem servir de alimento e que não fazem mal à saúde, mostrando um consumo pelos seres humanos sem a menor preocupação. Não havendo nenhuma crítica 
sobre o consumo desses alimentos industrializados, não tratando o quanto podem ser prejudiciais e que há indicadores de diversas doenças referentes a seu uso em excesso. Por trás desse discurso está essa indústria, que move bilhões de dólares por ano, alimentada por uma sociedade consumista e sedentária, proveniente da era dos fast food, do mundo globalizado, do bombardeio de informações e dessa correria do mundo moderno.

Além disso, ao utilizar o slogan "é impossível comer um sô" (cena 3, trecho 20) de uma famosa marca de salgadinhos, analiso tal trecho como uma argumentação de autoridade, segundo O. Ducrot (Koch, 1987), em que o filme pretende alcançar o objetivo de um discurso favorável a sociedade de consumo em que os espectadores estão inseridos. Dessa forma, não cria barreiras ou choques a quem o assiste. Tal argumentação de autoridade ocorre ao se fazer uso de provérbios, máximas, ditos populares e expressões consagradas em enunciados de discursos (Koch, 1987).

O filme trata a questão do grande desperdício dos seres humanos, que produzem uma grande quantidade de lixo, mais uma vez, a partir do ponto de vista dos animais humanizados, como indicado no trecho 22 da cena 3 ("O que eles fazem com o que não comem? Colocam em latas prateadas brilhantes. Só para nós."). Sendo que essa grande quantidade de lixo, que não serve mais para os seres humanos, passa a servir de alimento para esses animais, solucionando o problema que eles estão enfrentando, assim não precisam mais hibernar, tendo comida o ano todo. E, se o consumismo levar a obesidade, resolve-se facilmente com exercícios, como abordado na cena 3 no trecho 17 ("Mostra uma pessoa fazendo exercícios em um transfer: Isso deixa eles comerem mais comida."), logo não há problemas em comer o que se quer, a quantidade que se quer e a hora que se quer, sem precisar refletir também para a grande produção de lixo, oriunda desse consumismo exagerado.

Por último, mas não menos importante, quando trata os animais como pragas, porque são obrigados a invadir a área dos humanos em busca de alimento, colocando toda a culpa nos humanos que destruíram seu habitat, mostra uma solução para esse impasse quando, no final do filme, Hammy acha as nozes novamente e enche o tronco, não sendo necessário os animais continuarem "incomodando" os humanos. Todos passam a viver em harmonia, os humanos no condomínio e os animais no pequeno pedaço de floresta que lhes 
resta. Nesse momento, questiono de onde vem todo o alimento encontrado, se apenas sobrou uma pequena parcela da floresta original?

Então, o fechamento do filme mostra todos felizes, sem culpados nem vítimas. Os humanos podem viver em suas humildes mansões e os animais em seu remanescente de floresta, porém o mais importante é que estão todos satisfeitos, o que deixa o espectador satisfeito também.

\subsubsection{Reflexões sobre o discurso de filmes infanto-juvenis}

A humanização dos animais, que ocorre em todos os filmes do gênero, tem o objetivo de tornar as personagens mais carismáticas e mais atraentes para o público, ficando muito mais fácil gostar desses animais e fazer parte da história contada por eles.

O filme simula um discurso crítico, faz parecer que está preocupado com alguma problemática, porém não o faz de verdade, apenas coloca várias posições, sem tomar uma definição. Os "problemas" abordados pelo filme são simplesmente reprodução do que já está dito na sociedade, não trazem uma reflexão ao espectador. Porém, não pretendo generalizar essa reflexão para todos os filmes do gênero porque, nesse sentido, as mensagens são diferentes em contextos diferentes, sendo necessário analisar cada caso particularmente.

Tais filmes, que podem ser usados como recursos didáticos no ensino de ciências, devem representar algum sentido aos alunos, para criar significações a partir de seus enunciados, como aborda Osakabe (1979):

“...o locutor tem a necessidade de ter também garantido certo número de significações que considera suficientemente aceitas e assimiladas no ouvinte, cujo desconhecimento pode levar o ouvinte a simplesmente recusar o discurso que lhe é dirigido."

Osakabe (1979) faz uma discussão interessante sobre a perspectiva de O. Ducrot sobre as pressuposições em um discurso, a questão dos implícitos, que são usados porque toda informação explicitada torna-se um tema possível de discussão, logo evitar sua explicitação constitui evitar sujeitá-la à sua discussão. Nesta perspectiva, essa 
pressuposição deve-se ao fato de que não se explicitam objetos que se consideram suficientemente estratificados e aceitos (ou que se pressupõe serem estratificados e aceitos). Tais reflexões relacionam-se à M. Pêcheux na questão das imagens propostas, sendo uma das condições fundamentais de produção. Então, para M. Pêcheux, há um conjunto de imagens ou significações que ele pressupõe existirem no locutor e tem como base também outro conjunto de significações que o locutor pressupõe existirem nele. $\mathrm{O}$ conhecimento das significações pressupostas num discurso fornece muitas informações relacionadas a seu funcionamento.

\subsection{Análise do texto escrito dos alunos}

\subsubsection{Identificação dos conceitos científicos presentes nas respostas dos alunos}

A primeira análise deste trabalho é a identificação dos conceitos científicos presentes nas respostas dos alunos. É importante distinguir quais são os conceitos científicos que são apresentados no filme proposto na atividade e quais são os conceitos que não são apresentados pelo filme, mas que os alunos utilizam na construção de suas respostas. Os dezoito textos produzidos pelos alunos foram transcritos na tabela $1 \mathrm{e}$ apresentam seus conceitos científicos destacados do restante das respostas.

Nestas respostas dos alunos, destaco em negrito quando os alunos fazem alusão a um conceito científico ou uma mensagem presente no filme e $\underline{\text { sublinho } q u a n d o}$ os alunos fazem referência a algum conceito científico que não é apresentado no filme. Estes conceitos, quando apareceram no filme trabalhado, foram identificados por mim anteriormente. Essa identificação permite fazer reflexões sobre minha pergunta de investigação, para perceber que mensagens no filme são mais significativas aos alunos e de que maneira os alunos utilizam-nas na construção de suas argumentações.

Os grupos de respostas são denominados conforme explicado anteriormente:

- AN1, AN2 e AN3 - grupos de alunos que responderam à questão proposta representando os animais da floresta; 
- PE1, PE2 e PE3 - grupos de alunos que responderam à questão proposta representando as pessoas que moram na cidade sem as mínimas condições necessárias;

- $\mathrm{CC} 1, \mathrm{CC} 2$ e $\mathrm{CC} 3$ - grupos de alunos que responderam à questão proposta representando os comerciantes da cidade;

- CM1, CM2 e CM3 - grupos de alunos que responderam à questão proposta representando a comunidade que retira seu sustento da floresta;

- MA1, MA2 e MA3 - grupos de alunos que responderam à questão proposta representando o movimento ambientalista;

- TR1, TR2 e TR3 - grupos de alunos que responderam à questão proposta representando os trabalhadores da construtora de condomínios.

\begin{tabular}{|c|c|c|}
\hline $\begin{array}{c}\text { Grupo de } \\
\text { alunos }\end{array}$ & $\begin{array}{l}\text { Respostas dos alunos apresentando os conceitos } \\
\text { científicos presentes no filme (negrito) e os } \\
\text { conceitos científicos não trabalhados no filme } \\
\text { ( } \underline{\text { sublinhado })}\end{array}$ & Conceitos científicos \\
\hline AN1 & $\begin{array}{l}\text { Prefeito, nós em nome de todos os animais da } \\
\text { floresta, achamos pontos negativos e positivos em } \\
\text { construir o condomínio. Os pontos negativos são: } \\
\text { vocês vão nos matar, deixando-nos sem água, lar e } \\
\text { comida, a cadeia alimentar irá se prejudicar e } \\
\text { nós entraremos em extinção porque o ciclo da } \\
\text { cadeia alimentar irá mudar prejudicando nossas } \\
\text { vidas e dos predadores, para você isso não é nada, } \\
\text { mas para nós isso é muito importante, também } \\
\text { podemos levar choques com fios elétricos ou } \\
\text { sermos pegos por armadilhas. Os pontos positivos } \\
\text { são: será mais fácil arranjar comida, no inverno } \\
\text { podemos reutilizar as roupas que vocês jogam }\end{array}$ & $\begin{array}{l}\text { - Recursos } \\
\text { necessários para a } \\
\text { sobrevivência das } \\
\text { espécies: água, } \\
\text { moradia e alimento. } \\
\text { - Cadeia alimentar } \\
\text { - Extinção das } \\
\text { espécies } \\
\text { - Animais como } \\
\text { pragas naturais: } \\
\text { facilidade de arrumar } \\
\text { comida e perseguição } \\
\text { pelos seres humanos. }\end{array}$ \\
\hline
\end{tabular}




\begin{tabular}{|c|c|c|}
\hline & $\begin{array}{l}\text { fora. Chegando a esse ponto nós achamos que será } \\
\text { melhor não construir o condomínio, porque irá nos } \\
\text { prejudicar e prejudicar vocês. }\end{array}$ & \\
\hline AN2 & $\begin{array}{l}\text { Caro prefeito, nós, animais da floresta, estamos } \\
\text { mandando uma carta para falar sobre os horríveis } \\
\text { desmatamentos e poluições em nossa casa, floresta. } \\
\text { Nós exigimos nosso espaço! Vamos escrever uma } \\
\text { lista com tudo o que precisamos: comida, água, } \\
\text { árvores. Com isso, nós comunicamos que podem } \\
\text { matar apenas } 1 / 5 \text { de nossa floresta. Obrigado. }\end{array}$ & $\begin{array}{l}\text { - Desmatamento } \\
\text { - Poluição: a falta de } \\
\text { vegetação leva à } \\
\text { poluição. } \\
\text { - Recursos } \\
\text { necessários para a } \\
\text { sobrevivência das } \\
\text { espécies: alimento, } \\
\text { água e moradia. }\end{array}$ \\
\hline AN3 & $\begin{array}{l}\text { Caro prefeito, nós, animais da floresta, não } \\
\text { concordamos com o desmatamento de nossa casa, } \\
\text { porque primeiro não vamos ter onde morar, segundo } \\
\text { nós não sobreviveremos sem ter onde morar, } \\
\text { terceiro o ar ficará mais poluído, quarto você acha } \\
\text { que vale a pena acabar com a floresta só para } \\
\text { construir um condomínio? A fotossíntese não irá } \\
\text { existir na cidade. Por favor, esperamos que tome a } \\
\text { melhor decisão. }\end{array}$ & $\begin{array}{l}\text { - Desmatamento } \\
\text { - Poluição: a falta de } \\
\text { vegetação leva à } \\
\text { poluição. } \\
\text { - Fotossíntese: as } \\
\text { plantas realizam } \\
\text { fotossíntese. }\end{array}$ \\
\hline CM1 & $\begin{array}{l}\text { Caro prefeito, não gostamos muito dessa sua ideia. } \\
\text { Tudo bem, haverá mais lugares de lazer, de trabalho } \\
\text { para nós e também mais moradias, mas também vão } \\
\text { causar mortes, não teremos mais sustentação, } \\
\text { causará um desastre na floresta, estragará a } \\
\text { moradia dos animais, acabará com os nossos } \\
\text { recursos naturais e extinção de alguns animais. } \\
\text { Mas, se o senhor vai construir esse tal de } \\
\text { condomínio, deve deixar um espaço para os animais, }\end{array}$ & $\begin{array}{l}\text { - Recursos } \\
\text { necessários à } \\
\text { sobrevivência das } \\
\text { espécies: alimento e } \\
\text { moradia (habitat). } \\
\text { - Extinção das } \\
\text { espécies. } \\
\text { - Plantio de árvores } \\
\text { em outro local. }\end{array}$ \\
\hline
\end{tabular}




\begin{tabular}{|c|c|c|}
\hline & $\begin{array}{l}\text { pois esse é o habitat deles, também deve deixar } \\
\text { recursos para eles e para nós. Prefeito, se você } \\
\text { gostou de nossa ideia, então demore um bom tempo, } \\
\text { para conseguirmos outro habitat para os animais e } \\
\text { também outro lugar para que retirássemos os nossos } \\
\text { sustentos. Há mais um pedido: se você construísse } \\
\text { mais algumas florestas (já que só tem essa } \\
\text { pequenina), aí sim você poderia fazer o } \\
\text { condomínio, pois teríamos outros lugares } \\
\text { melhores. Obrigado por sua consideração. } \\
\text { Esperamos que goste de nossas ideias e as atenda. }\end{array}$ & \\
\hline $\mathrm{CM} 2$ & $\begin{array}{l}\text { Caro prefeito, como moradores especializados em } \\
\text { Biologia um desmatamento feito para o aumento de } \\
\text { condomínios provoca reações na natureza, como, } \\
\text { por exemplo, invasões de procura de comida no } \\
\text { território urbano, por extinto próprio dos } \\
\text { animais. Por causa do período de hibernação, a } \\
\text { gordura que os animais armazenavam se foi. Por } \\
\text { causa do período da hibernação ocorrer durante } \\
\text { muitos meses, faz com que eles fiquem mais } \\
\text { famintos do que o normal. Provoca sujeira, pois } \\
\text { os animais vasculham as latas de lixo a procura } \\
\text { de alimento. Isso irrita um pouco os moradores o } \\
\text { que fazem eles tomarem atitudes agressivas. Peço a } \\
\text { todos que colaborem com os recursos ambientais. } \\
\text { Agradecemos pela atenção. }\end{array}$ & $\begin{array}{l}\text { - Desmatamento } \\
\text { - Animais como } \\
\text { pragas naturais. } \\
\text { - Conceito de } \\
\text { hibernação }\end{array}$ \\
\hline CM3 & $\begin{array}{l}\text { Caro prefeito, nós não admitimos que você desmate } \\
\text { a floresta de onde tiramos nosso sustento. Nossa } \\
\text { sobrevivência depende dessa floresta. O único ponto } \\
\text { positivo dessa construção é que vai haver mais }\end{array}$ & - Desmatamento \\
\hline
\end{tabular}




\begin{tabular}{|c|c|c|}
\hline & $\begin{array}{l}\text { empregos e mais lazer para os cidadãos. Você } \\
\text { sempre tem comida, mas pense nas pessoas que não } \\
\text { têm dinheiro para ter um café-da-manhã, um almoço } \\
\text { ou um jantar decente. Pense bem antes de fazer esse } \\
\text { condomínio. Agradecemos pela sua atenção. }\end{array}$ & \\
\hline $\mathrm{CC} 1$ & $\begin{array}{l}\text { Caro prefeito, gostaríamos de estabelecer nossas } \\
\text { opiniões sobre as novas construções da cidade. } \\
\text { Nossas opiniões negativas são: O desmatamento } \\
\text { das florestas e isso causa um grande aumento do } \\
\text { clima e as pessoas terão mais custos com impostos. } \\
\text { Pontos positivos: um dos pontos positivos é o } \\
\text { aumento do comércio, mais lazer para os moradores } \\
\text { e os comerciantes vão lucrar muito. Muito obrigado } \\
\text { (a) pela sua atenção. Então, nós gostaríamos que } \\
\text { construa o condomínio, mas não desmatando toda a } \\
\text { floresta. }\end{array}$ & $\begin{array}{l}\text { - Desmatamento } \\
\text { - Aquecimento global } \\
\underline{\text { causado pelo }} \\
\underline{\text { desmatamento }}\end{array}$ \\
\hline $\mathrm{CC} 2$ & $\begin{array}{l}\text { Caro prefeito, listamos pontos positivos e negativos } \\
\text { da construção do condomínio. Os pontos negativos } \\
\text { são a área desmatada, que fará falta para os } \\
\text { animais, deixando eles sem abrigo e sem comida. } \\
\text { E por outro lado, terá mais lazer para os humanos, } \\
\text { gerando mais empregos. É uma decisão difícil para } \\
\text { nós, por isso queremos que escolha a melhor opção. } \\
\text { Caso faça o condomínio esperamos que pense na } \\
\text { mata e nos animais. Aguardamos resposta. }\end{array}$ & $\begin{array}{l}\text { - Desmatamento } \\
\text { - Recursos } \\
\text { necessários para a } \\
\text { sobrevivência das } \\
\text { espécies: moradia } \\
\text { (habitat) e alimento. }\end{array}$ \\
\hline CC3 & $\begin{array}{l}\text { Caro prefeito, nós do comércio observamos e } \\
\text { analisamos sua ideia de expandir a cidade e o } \\
\text { condomínio. A sua ideia será apoiada por nós, } \\
\text { mesmo sendo péssima idéia em relação ao meio } \\
\text { ambiente e ao clima. }\end{array}$ & \\
\hline
\end{tabular}




\begin{tabular}{|c|c|c|}
\hline PE1 & $\begin{array}{l}\text { Seu Prefeito, há mais pontos positivos do que } \\
\text { negativos, pois os negativos prejudicam mais a } \\
\text { natureza. Os pontos positivos são: conforto, lazer } \\
\text { para a comunidade, (...) tem mais comunicação entre } \\
\text { pessoas. E os pontos negativos são: o } \\
\text { desmatamento com parte da floresta que causa o } \\
\underline{\text { aquecimento global (causando enchentes e essas }} \\
\underline{\text { coisas) e tem mais gastos de água. Por isso estamos }} \\
\text { contra a construção do condomínio. }\end{array}$ & $\begin{array}{l}\text { - Desmatamento } \\
\text { - Aquecimento global } \\
\text { causado pelo } \\
\underline{\text { desmatamento }} \\
\text { - Consequências do } \\
\underline{\text { aquecimento global: }} \\
\text { enchentes } \\
\text { - Desperdício de água. }\end{array}$ \\
\hline PE2 & $\begin{array}{l}\text { Cara Prefeitura, se decidirem construir um } \\
\text { condomínio em nossa cidade, teríamos mais } \\
\text { doenças e as pessoas morreriam mais cedo. Mas, se } \\
\text { construir teremos um conforto melhor e } \\
\text { conheceríamos mais pessoas. Mas teríamos pragas, } \\
\text { o ar ficaria impuro. Seria mais reconhecida pelo } \\
\text { dinheiro, assim atrairiam mais bandidos, levando a } \\
\text { mais assaltos. Mas, prefeito, como as pessoas irão } \\
\text { pagar o condomínio? Esperamos seu retorno e que } \\
\text { faça a coisa certa! }\end{array}$ & $\begin{array}{l}\text { - Animais como } \\
\text { pragas naturais e } \\
\text { causadores de } \\
\text { doenças. }\end{array}$ \\
\hline PE3 & $\begin{array}{l}\text { Prezado prefeito, sua construção, por um lado, pode } \\
\text { nos ajudar melhorando nossa condição de vida, mas } \\
\text { por outro lado ela iria prejudicar muito o meio } \\
\text { ambiente causando muitos danos a ele e nós nos } \\
\text { preocupamos com isso. Queremos morar em um } \\
\text { lugar melhor, mas para isso é preciso que você não } \\
\text { prejudique o meio ambiente para não ficarmos tão } \\
\text { preocupados. Obrigado! }\end{array}$ & \\
\hline MA1 & $\begin{array}{l}\text { Caro prefeito, em relação a sua proposta, já } \\
\text { decidimos. Nós gostaríamos que a floresta ficasse } \\
\text { em seu lugar, porque se nós destruirmos essa mata }\end{array}$ & $\begin{array}{l}\text { - Desmatamento } \\
\text { - Recursos } \\
\text { necessários para a }\end{array}$ \\
\hline
\end{tabular}




\begin{tabular}{|c|c|c|}
\hline & $\begin{array}{l}\text { teremos mais espaço para o lazer, para se divertir, } \\
\text { estudar, entre outros. Mas também há um lado ruim, } \\
\text { porque iremos destruir o meio ambiente e o } \\
\text { habitat dos animais, para fazermos uma coisa que } \\
\text { já temos. Se nós não destruirmos, estaremos } \\
\text { ajudando a preservar o meio ambiente e o habitat } \\
\text { dos animais. Nossa decisão é não destruir essa } \\
\text { mata, porque nós precisamos dela para sobreviver. }\end{array}$ & $\begin{array}{l}\text { sobrevivência das } \\
\text { espécies: moradia } \\
\text { (habitat). }\end{array}$ \\
\hline MA2 & $\begin{array}{l}\text { Caro prefeito, nós achamos que desmatar uma parte } \\
\text { da floresta só para construir um prédio já se torna } \\
\text { um exagero. Embora a nossa cidade seja pequena e } \\
\text { precise de prédios, a floresta é ainda mais } \\
\text { importante, pois nem todo o lugar tem floresta. } \\
\text { Teríamos mais um lugar para morar, mais lazer, mas } \\
\text { a consequência que teremos é que desmataremos } \\
\text { árvores, mata, etc... E como sabem as árvores são } \\
\text { fundamentais para a nossa vida, pois elas } \\
\text { (árvores) absorvem a fumaça e liberam o ar } \\
\text { limpo. Aguardamos um retorno. }\end{array}$ & $\begin{array}{l}\text { - Desmatamento } \\
\text { - Poluição: a falta de } \\
\text { vegetação leva à } \\
\text { poluição. }\end{array}$ \\
\hline MA3 & $\begin{array}{l}\text { Caro Senhor Prefeito, nós, ambientalistas da cidade, } \\
\text { estamos protestando sobre o desmatamento da } \\
\text { cidade para a construção de um condomínio, porque } \\
\text { há vários pontos negativos: o ar será mais poluído, } \\
\text { pois não terá mais árvores, os animais que moram } \\
\text { na floresta, perderão suas casas, se não existirem } \\
\text { plantas, não existirão herbívoros, não existirão } \\
\text { carnívoros e se não existirão carnívoros e } \\
\text { herbívoros, não existirá mais vida. Mas, também } \\
\text { há vários pontos positivos: a moradia das pessoas } \\
\text { será melhor, elas terão melhores condições de vida. }\end{array}$ & $\begin{array}{l}\text { - Desmatamento } \\
\text { - Poluição: a falta de } \\
\text { vegetação leva à } \\
\text { poluição. } \\
\text { - Recursos } \\
\text { necessários à } \\
\text { sobrevivência das } \\
\text { espécies: moradia } \\
\text { (habitat). } \\
\text { - Cadeia alimentar }\end{array}$ \\
\hline
\end{tabular}




\begin{tabular}{|c|c|c|}
\hline & Esperamos que o senhor tome a decisão certa. & \\
\hline TR1 & $\begin{array}{l}\text { Caro prefeito, nós trabalhadores da construtora de } \\
\text { condomínios, poderíamos desmatar uma pequena } \\
\text { parte da floresta para construir o condomínio que } \\
\text { ocupe menos espaço da floresta, por um espaço } \\
\text { razoável. Se não construirmos o condomínio, não } \\
\text { teremos salários, isso afetaria as ações da empresa. } \\
\text { Tudo o que desmatarmos será reposto em outro } \\
\text { lugar. Esperamos que compreenda. }\end{array}$ & $\begin{array}{l}\text { - Desmatamento } \\
\text { - Plantio de árvores } \\
\text { em outro local }\end{array}$ \\
\hline TR2 & $\begin{array}{l}\text { Senhor prefeito, como trabalhadores da obra nova, } \\
\text { dizemos que essa obra só trará coisas ruins para } \\
\text { nossa cidade. Os únicos pontos positivos são: teria } \\
\text { mais moradia, valorizaria a região e teriam mais } \\
\text { empregos. Já os pontos negativos são muitos: } \\
\text { acabariam com todo o verde, ou seja, } \\
\text { desmatariam, gastaria mais água, por causa de } \\
\text { eletricidade e também como as árvores não estariam } \\
\text { mais lá não daria para transformar gás carbônico em } \\
\text { ar (oxigênio). Realmente para nós, trabalhadores, } \\
\text { seria bom por causa do salário, mas pensando na } \\
\text { população da cidade, não valeria a pena. } \\
\text { Aguardamos retorno. }\end{array}$ & $\begin{array}{l}\text { - Desmatamento } \\
\text { - Água produz } \\
\underline{\text { eletricidade }} \\
\text { - Fotossíntese das } \\
\text { plantas: transformação } \\
\underline{\text { de gás carbônico em }} \\
\underline{\text { oxigênio. }} \\
\text { - Desperdício de água }\end{array}$ \\
\hline TR3 & $\begin{array}{l}\text { Caro prefeito (...), temos o prazer de informar a } \\
\text { Vossa Senhoria que estamos de parcial acordo com } \\
\text { sua respeitável proposta. Nossa condição é que } \\
\text { possamos incluir dentro do condomínio (...) uma } \\
\text { área das árvores que replantaremos para } \\
\text { compensar o desmatamento. (...) Então, os } \\
\text { moradores poderão interagir diretamente com a }\end{array}$ & $\begin{array}{l}\text { - Plantio das árvores } \\
\text { em outro local } \\
\text { - Desmatamento }\end{array}$ \\
\hline
\end{tabular}




\begin{tabular}{|l|l|l|l|}
\hline & $\begin{array}{l}\text { natureza. O projeto levará seis meses para ser } \\
\text { completo. Gratos. }\end{array}$ & \\
\hline
\end{tabular}

Tabela 1 - Respostas dos alunos identificando os conceitos científicos e as mensagens apresentadas no filme.

\subsubsection{Discussão sobre os conceitos científicos empregados nas respostas dos alunos}

Para a discussão dos conceitos científicos empregados nas respostas dos alunos, faço uma lista dos termos ou conceitos científicos que aparecem e relaciono com as mensagens presentes no filme.

- Desmatamento: Dos conceitos científicos empregados nas respostas dos alunos o desmatamento foi o que apareceu na maioria das respostas (treze respostas), isso se deve ao emprego do termo "desmatar" no próprio problema sociocientífico proposto para os alunos resolverem: "deverá desmatar uma área de floresta”. Percebo que os alunos entendem o conceito e utilizam-no de maneira correta em todas as suas respostas. Esse conceito é o tema central do filme trabalhado como também do problema proposto. Entender o seu significado e suas consequências para o meio ambiente e para os que dependem dele é importante para resolver a questão levantada. A escolha dos alunos por citar esse termo deve-se, principalmente, à atividade proposta.

- Extinção das espécies: A preocupação com a extinção das espécies aparece em duas respostas dos alunos (AN1 e CM1). Esse conceito é bastante discutido no filme, no qual os animais necessitam da floresta para viver e obter seu alimento; sem a floresta, eles vão entrar em extinção. Analiso que alguns alunos usam esse conceito para justificar suas respostas à questão proposta por ser um conceito central presente no filme assistido e trazer um apelo emocional para convencer o leitor.

- Recursos necessários para a sobrevivência das espécies: Alguns grupos de alunos fazem alusão à importância da água (AN1 e AN2), da disponibilidade de alimento (AN1, AN2, 
CM1 e CC2) e de um local para morar (AN1, AN2, CM1, CC2, MA1 e MA3) como itens imprescindíveis para a sobrevivência dos animais. Todos esses recursos são apresentados no filme de maneira lúdica e percebe-se que os alunos entendem-nos como necessários para as espécies, utilizando-os para embasar suas respostas.

- Animais como pragas naturais: Em diferentes momentos do filme, os animais são apresentados como pragas naturais, eles aparecem roubando os alimentos dos seres humanos e, quando são vistos pelos humanos, é motivo de pânico, gritaria e correria. Os humanos contratam um exterminador para acabar com esse "problema" que está afligindo os moradores do condomínio. Porém, apesar dessa visão que o filme transmite, de que os animais são pragas, apenas uma resposta de alunos menciona a presença dos animais como um aspecto negativo (PE2). Na maioria das respostas, essa característica dos animais de roubarem alimento e até as roupas dos humanos é vista como necessária para eles, pois perderam sua floresta, e precisam sobreviver. $\mathrm{O}$ filme, além de retratar a visão negativa pelo lado dos seres humanos, retrata também a visão positiva pelo lado dos animais, de que eles fazem isso por necessidade, não por escolha. Se os animais estão nessa situação, os culpados são os seres humanos que acabaram com suas casas e, consequentemente, com seus alimentos. Esse olhar pelo lado dos animais é mais trabalhado no filme, usando como recurso os animais humanizados, "fofinhos", "bonitinhos" e mais carismáticos do que os seres humanos, fazendo o público torcer por eles, já que são as vítimas da estória. Devido a isso, alguns grupos (AN1, AN2, AN3, CM1, CM2, CC2, MA1 e MA3) defendem os animais na construção de suas respostas, preocupando-se com a sobrevivência deles no caso de ocorrer o desmatamento. Esses grupos fazem essa escolha motivada pela emoção, que o filme consegue transmitir com eficiência.

- Cadeia alimentar: Em algumas respostas, os alunos apresentam o conceito de cadeia alimentar, relacionando a presença dos vegetais à presença de outros seres vivos. Concluindo que, se um elo da cadeia desaparece, toda a cadeia alimentar será prejudicada com isso. Esse conceito é apresentado no filme relacionando a falta de vegetação à falta de alimentos para os animais, sendo que todos os animais do filme são caracterizados como 
herbívoros (todos comem as nozes que juntam durante todo o ano). O conceito de cadeia alimentar não é diretamente abordado pelo filme, uma vez que o filme apresenta soluções para esse problema: os animais podem buscar alimento na casa dos seres humanos. Foram poucos os grupos (AN1 e MA3) que utilizaram o conceito de cadeia alimentar na construção de suas respostas, o que mostra que a mensagem que os alunos captam do filme inclui a inserção de uma nova possibilidade de alimentação para os animais, como proposto pelo recurso.

- Aquecimento global: Uma questão que está sendo bastante divulgada nos meios de comunicação é o problema do aquecimento global. O filme não aborda esse assunto em nenhum momento, nem de maneira indireta. Apesar disso, alguns grupos relacionam a falta de vegetação (problema apresentado na questão proposta e no filme) ao problema do aquecimento global. Esse conceito influenciou alguns grupos (CC1 e PE1) a utilizarem-no, apresentando suas consequências para justificarem suas respostas à questão proposta.

- Poluição: A ideia de que a falta de vegetação leva à poluição do ambiente aparece em algumas respostas (AN2, AN3, MA2 e MA3), os alunos mencionam que as plantas "limpam" o ar, logo, sem a presença delas, o ar ficaria muito poluído ${ }^{3}$. O filme não faz alusão a essa questão, porém a mídia debate e alerta bastante sobre esse assunto, principalmente no local em que os sujeitos da pesquisa residem (município de São Paulo). Dessa forma, esses grupos de alunos são influenciados pela mídia na construção de suas respostas e não pelo filme apresentado.

- Fotossíntese: O conceito de que as plantas realizam fotossíntese, aparece em duas respostas. Esse conceito não é trabalhado no filme, porém havia sido trabalhado em sala de aula pela professora da turma em aulas anteriores. O grupo AN3 apresentou o termo de maneira descontextualizada, enquanto o grupo TR2 explicou o que significa esse processo,

\footnotetext{
${ }^{3}$ Esse conceito dos estudantes de que os vegetais "limpam" o ar deve ser interpretado da seguinte maneira: como os vegetais realizam a fotossíntese, absorvendo gás carbônico e liberando gás oxigênio, e o gás carbônico acelera o processo do aquecimento global sendo prejudicial ao meio ambiente e ao clima, a retirada do gás carbônico tornaria o ar "limpo".
} 
justificando que é importante para absorver gás carbônico e liberar gás oxigênio. Esses dois grupos consideraram como um bom argumento, mencionar que sem a vegetação, não haveria fotossíntese. Porém, esse conceito científico não foi significativo na construção das respostas dos alunos.

- Desperdício de água: as reservas de água estão diminuindo. O aumento da poluição de rios, lagos e lagoas não permite que a água complete seu ciclo e que esteja própria para o consumo. Essa questão tem sido bastante discutida nos diferentes meios de comunicação, porém ela não é apresentada no filme. Os alunos fazem menção a essa problemática por influência da mídia e não do filme trabalhado.

- Plantio das árvores: Na elaboração de suas respostas, há grupos que aceitam que ocorra o desmatamento para a construção do condomínio (CM1, TR1 e TR3), caso haja o plantio das árvores em outro lugar, permitindo que os animais vivam nesse novo habitat criado para eles. Essa resposta mostra que os alunos optam a favor à construção do condomínio, já que representam os grupos dos trabalhadores da construtora (TR1 e TR3), porém estão sensibilizados com o "drama" vivido pelos animais, o qual é bastante abordado no filme em questão. Os animais da floresta são mostrados como vítimas em relação ao desmatamento, por isso essa visão fica bastante enraizada no imaginário dos alunos, não permitindo que eles sejam completamente a favor à construção do condomínio, sem que reflitam e proponham uma solução para isso. Os alunos, então, apresentam uma proposta para "salvar" esses animais, o plantio das árvores em outro local.

- Hibernação: Apesar de esse conceito ter sido bastante difundido no filme analisado, os alunos não utilizaram esse conceito na elaboração de suas respostas. $\mathrm{O}$ desenvolvimento das respostas tinha o objetivo de responder à questão proposta, esse conceito de hibernação não trazia elementos suficientes para responder à atividade, por isso não foi "escolhido" pelos alunos para justificar as respostas elaboradas. Apenas o grupo CM2 utiliza o conceito de hibernação para justificar porque os animais buscam alimentos nas casas dos seres humanos. 


\subsubsection{Identificação dos conceitos científicos e das mensagens do filme nas respostas dos alunos a partir do padrão de argumentação de Toulmin (2006)}

A categorização dos elementos dos argumentos presentes nas respostas dos alunos será apresentada na tabela 2. Faço a categorização das respostas a partir do padrão de argumentação de Toulmin (2006), que será imprescindível para a análise posterior.

A maioria das respostas que os alunos desenvolveram são longas, devido a isso os elementos que aparecem nos argumentos podem servir como dado, garantia e conclusão em diferentes enunciados dos argumentos. Dessa maneira, um mesmo dado pode servir para diferentes enunciados, assim como uma conclusão pode ser feita utilizando-se de várias afirmações (garantias, dados e refutadores). Faço a separação dos enunciados por linhas apenas para representar de maneira organizada os elementos presentes nos argumentos dos alunos. O argumento produzido pelos alunos deve ser entendido como um todo e não deve ser lido como argumento separados.

Assinalo em negrito nas respostas dos alunos quando eles fazem referência a episódios apresentados no filme e quando eles utilizam os conceitos científicos presentes no filme para responder à questão. Não foram assinalados os conceitos científicos que não são ilustrados no filme, tais conceitos já foram discutidos anteriormente. Essa categorização tem como objetivo: identificar em que elementos dos argumentos (dado, garantia, apoio, conclusão, qualificador e refutador) os alunos utilizam os conceitos do filme e analisar se os alunos constroem argumentos formalmente válidos utilizando, para isso, conceitos científicos e mensagens presentes no filme. 


\begin{tabular}{|c|c|c|c|c|c|c|}
\hline \multirow[b]{2}{*}{$\begin{array}{l}\text { Grupo } \\
\text { de } \\
\text { alunos }\end{array}$} & \multicolumn{6}{|c|}{ Argumentos } \\
\hline & $\begin{array}{c}\text { Dado } \\
\text { (dado que...) }\end{array}$ & Conclusão & $\begin{array}{l}\text { Garantia } \\
\text { (já que....) }\end{array}$ & $\begin{array}{l}\text { Apoio (por } \\
\text { conta de...) }\end{array}$ & $\begin{array}{l}\text { Qualifica- } \\
\text { dor }\end{array}$ & $\begin{array}{c}\text { Refutador } \\
\text { (a menos } \\
\text { que...) }\end{array}$ \\
\hline \multirow[t]{3}{*}{ AN1 } & $\begin{array}{l}\text {... achamos } \\
\text { pontos } \\
\text { negativos e } \\
\text { positivos em } \\
\text { construir o } \\
\text { condomínio }\end{array}$ & $\begin{array}{l}\text { Chegando a } \\
\text { esse ponto nós } \\
\text { achamos que } \\
\text { será melhor não } \\
\text { construir o } \\
\text { condomínio, } \\
\text { porque irá nos } \\
\text { prejudicar e } \\
\text { prejudicar } \\
\text { vocês. }\end{array}$ & $\begin{array}{l}\text { Os pontos } \\
\text { negativos são: } \\
\text { vocês vão nos } \\
\text { matar, } \\
\text { deixando-nos } \\
\text { sem água, lar e } \\
\text { comida, a } \\
\text { cadeia } \\
\text { alimentar irá } \\
\text { se prejudicar e } \\
\text { nós } \\
\text { entraremos em } \\
\text { extinção }\end{array}$ & \multirow[t]{3}{*}{$\begin{array}{l}\text { porque o ciclo } \\
\text { da cadeia } \\
\text { alimentar irá } \\
\text { mudar } \\
\text { prejudicando } \\
\text { nossas vidas e } \\
\text { dos predadores }\end{array}$} & & \\
\hline & & & $\begin{array}{l}\text { também } \\
\text { podemos levar } \\
\text { choques com } \\
\text { fios elétricos } \\
\text { ou sermos } \\
\text { pegos por } \\
\text { armadilhas }\end{array}$ & & & \\
\hline & & & $\begin{array}{l}\text { Os pontos } \\
\text { positivos são: } \\
\text { será mais fácil } \\
\text { arranjar } \\
\text { comida, no } \\
\text { inverno } \\
\text { podemos } \\
\text { reutilizar as } \\
\text { roupas que } \\
\text { vocês jogam } \\
\text { fora }\end{array}$ & & & \\
\hline
\end{tabular}




\begin{tabular}{|c|c|c|c|c|c|c|}
\hline & $\begin{array}{c}\text { Dado } \\
\text { (dado que...) }\end{array}$ & Conclusão & $\begin{array}{r}\text { Garantia } \\
\text { (já que...) }\end{array}$ & $\begin{array}{l}\text { Apoio (por } \\
\text { conta de...) }\end{array}$ & $\begin{array}{l}\text { Qualifica- } \\
\text { dor }\end{array}$ & $\begin{array}{c}\text { Refutador } \\
\text { (a menos } \\
\text { que...) }\end{array}$ \\
\hline \multirow[t]{2}{*}{ AN2 } & $\begin{array}{l}\text { Nós exigimos } \\
\text { nosso espaço! }\end{array}$ & $\begin{array}{l}\text { Com isso, nós } \\
\text { comunicamos } \\
\text { que podem } \\
\text { matar apenas } \\
1 / 5 \text { de nossa } \\
\text { floresta. }\end{array}$ & $\begin{array}{l}\text { nós animais da } \\
\text { floresta estamos } \\
\text { mandando uma } \\
\text { carta para falar } \\
\text { sobre os } \\
\text { horríveis } \\
\text { desmatamento } \\
\text { s e poluições } \\
\text { em nossa casa, } \\
\text { floresta. } \\
\text { Vamos escrever } \\
\text { uma lista com } \\
\text { tudo o que } \\
\text { precisamos: } \\
\text { comida, água, } \\
\text { árvores. }\end{array}$ & & & \\
\hline & $\begin{array}{c}\text { Dado } \\
\text { (dado que....) }\end{array}$ & Conclusão & $\begin{array}{l}\text { Garantia } \\
\text { (já que...) }\end{array}$ & $\begin{array}{l}\text { Apoio (por } \\
\text { conta de...) }\end{array}$ & $\begin{array}{l}\text { Qualifica- } \\
\text { dor }\end{array}$ & $\begin{array}{c}\text { Refutador } \\
\text { (a menos } \\
\text { que...) }\end{array}$ \\
\hline \multirow[t]{5}{*}{ AN3 } & $\begin{array}{l}\text { primeiro não } \\
\text { vamos ter } \\
\text { onde morar }\end{array}$ & $\begin{array}{l}\text { segundo nós } \\
\text { não } \\
\text { sobrevivere- } \\
\text { mos }\end{array}$ & $\begin{array}{l}\text { sem ter onde } \\
\text { morar }\end{array}$ & \multirow[t]{5}{*}{$\begin{array}{l}\text { A fotossíntese } \\
\text { não irá existir na } \\
\text { cidade. }\end{array}$} & & \\
\hline & & $\begin{array}{l}\text { não } \\
\text { concordamos } \\
\text { com o } \\
\text { desmatamento } \\
\text { de nossa casa }\end{array}$ & & & & \\
\hline & & $\begin{array}{l}\text { terceiro o ar } \\
\text { ficará mais } \\
\text { poluído }\end{array}$ & & & & \\
\hline & & & $\begin{array}{l}\text { você acha que } \\
\text { vale a pena } \\
\text { acabar com a } \\
\text { floresta só } \\
\text { para construir } \\
\text { um } \\
\text { condomínio? }\end{array}$ & & & \\
\hline & & $\begin{array}{l}\text { esperamos que } \\
\text { tome a melhor } \\
\text { decisão. }\end{array}$ & & & & \\
\hline
\end{tabular}




\begin{tabular}{|c|c|c|c|c|c|c|}
\hline & $\begin{array}{c}\text { Dado } \\
\text { (dado que....) }\end{array}$ & Conclusão & $\begin{array}{l}\text { Garantia } \\
\text { (já que...) }\end{array}$ & $\begin{array}{l}\text { Apoio (por } \\
\text { conta de...) }\end{array}$ & $\begin{array}{l}\text { Qualifica- } \\
\text { dor }\end{array}$ & $\begin{array}{l}\text { Refutador } \\
\text { (a menos } \\
\text { que...) }\end{array}$ \\
\hline \multirow[t]{4}{*}{ CM1 } & $\begin{array}{l}\text { vão causar } \\
\text { mortes, não } \\
\text { teremos mais } \\
\text { sustentação, } \\
\text { causará um } \\
\text { desastre na } \\
\text { floresta, } \\
\text { estragará a } \\
\text { moradia dos } \\
\text { animais, } \\
\text { acabará com } \\
\text { os nossos } \\
\text { recursos } \\
\text { naturais e } \\
\text { extinção de } \\
\text { alguns } \\
\text { animais. }\end{array}$ & $\begin{array}{l}\text { não gostamos } \\
\text { muito dessa sua } \\
\text { ideia. }\end{array}$ & & & & \multirow[t]{4}{*}{$\begin{array}{l}\text { haverá mais } \\
\text { lugares de } \\
\text { lazer, de } \\
\text { trabalho para } \\
\text { nós e } \\
\text { também } \\
\text { mais } \\
\text { moradias }\end{array}$} \\
\hline & $\begin{array}{l}\text { se o senhor vai } \\
\text { construir esse } \\
\text { tal de } \\
\text { condomínio }\end{array}$ & $\begin{array}{l}\text { deve deixar um } \\
\text { espaço para os } \\
\text { animais }\end{array}$ & $\begin{array}{l}\text { pois esse é o } \\
\text { habitat deles }\end{array}$ & & & \\
\hline & & $\begin{array}{l}\text { também deve } \\
\text { deixar recursos } \\
\text { para eles e para } \\
\text { nós }\end{array}$ & & & & \\
\hline & $\begin{array}{l}\text { se você gostou } \\
\text { de nossa ideia }\end{array}$ & $\begin{array}{l}\text { então demore } \\
\text { um bom tempo } \\
\text { para } \\
\text { conseguirmos } \\
\text { outro habitat } \\
\text { para os animais } \\
\text { e também outro } \\
\text { lugar para que } \\
\text { retirássemos os } \\
\text { nossos } \\
\text { sustentos. }\end{array}$ & & & & \\
\hline
\end{tabular}




\begin{tabular}{|c|c|c|c|c|c|c|}
\hline & $\begin{array}{l}\text { se você } \\
\text { construísse } \\
\text { mais algumas } \\
\text { florestas }\end{array}$ & $\begin{array}{l}\text { aí sim você } \\
\text { poderia fazer o } \\
\text { condomínio. } \\
\text { Esperamos que } \\
\text { goste de nossas } \\
\text { ideias e as } \\
\text { atenda. }\end{array}$ & $\begin{array}{l}\text { já que só tem } \\
\text { essa } \\
\text { pequenina; } \\
\text { pois teríamos } \\
\text { outros lugares } \\
\text { melhores. }\end{array}$ & & $\begin{array}{l}\text { Há mais } \\
\text { um pedido }\end{array}$ & \\
\hline & $\begin{array}{c}\text { Dado } \\
\text { (dado que....) }\end{array}$ & Conclusão & $\begin{array}{l}\text { Garantia } \\
\text { (já que...) }\end{array}$ & $\begin{array}{l}\text { Apoio (por } \\
\text { conta de...) }\end{array}$ & $\begin{array}{l}\text { Qualifica- } \\
\text { dor }\end{array}$ & $\begin{array}{l}\text { Refutador } \\
\text { (a menos } \\
\text { que...) }\end{array}$ \\
\hline CM2 & $\begin{array}{l}\text { Um } \\
\text { desmatamen- } \\
\text { to feito para o } \\
\text { aumento de } \\
\text { condomínios }\end{array}$ & $\begin{array}{l}\text { Isso irrita um } \\
\text { pouco } \\
\text { moradores os } \\
\text { que fazem eles } \\
\text { tomarem }\end{array}$ & $\begin{array}{l}\text { como } \\
\text { moradores } \\
\text { especializados } \\
\text { em Biologia }\end{array}$ & & & \\
\hline & $\begin{array}{l}\text { provoca } \\
\text { reações na } \\
\text { natureza }\end{array}$ & $\begin{array}{l}\text { atitudes } \\
\text { agressivas. }\end{array}$ & $\begin{array}{l}\text { invasões de } \\
\text { procura de } \\
\text { comida no } \\
\text { território } \\
\text { urbano }\end{array}$ & $\begin{array}{l}\text { por extinto } \\
\text { próprio dos } \\
\text { animais }\end{array}$ & & \\
\hline & & & $\begin{array}{l}\text { a gordura que } \\
\text { os animais } \\
\text { armazenavam } \\
\text { se foi }\end{array}$ & $\begin{array}{l}\text { Por causa do } \\
\text { período de } \\
\text { hibernação }\end{array}$ & & \\
\hline & & & $\begin{array}{l}\text { faz com que } \\
\text { eles fiquem } \\
\text { mais famintos } \\
\text { do que o } \\
\text { normal. }\end{array}$ & $\begin{array}{l}\text { Por causa do } \\
\text { período da } \\
\text { hibernação } \\
\text { ocorrer durante } \\
\text { muitos meses }\end{array}$ & & \\
\hline & $\begin{array}{l}\text { Provoca } \\
\text { sujeira, }\end{array}$ & & $\begin{array}{l}\text { pois os animais } \\
\text { vasculham as } \\
\text { latas de lixo a } \\
\text { procura de } \\
\text { alimento. }\end{array}$ & & & \\
\hline & & $\begin{array}{l}\text { Peço a todos } \\
\text { que colaborem } \\
\text { com os recursos } \\
\text { ambientais. }\end{array}$ & & & & \\
\hline
\end{tabular}




\begin{tabular}{|c|c|c|c|c|c|c|}
\hline & $\begin{array}{c}\text { Dado } \\
\text { (dado que....) }\end{array}$ & Conclusão & $\begin{array}{l}\text { Garantia } \\
\text { (já que...) }\end{array}$ & $\begin{array}{l}\text { Apoio (por } \\
\text { conta de...) }\end{array}$ & $\begin{array}{l}\text { Qualifica- } \\
\text { dor }\end{array}$ & $\begin{array}{c}\text { Refutador } \\
\text { (a menos } \\
\text { que...) }\end{array}$ \\
\hline \multirow[t]{3}{*}{ CM3 } & $\begin{array}{l}\text { Nossa } \\
\text { sobrevivência } \\
\text { depende dessa } \\
\text { floresta }\end{array}$ & $\begin{array}{l}\text { nós não } \\
\text { admitimos que } \\
\text { você desmate a } \\
\text { floresta }\end{array}$ & \multirow[t]{2}{*}{$\begin{array}{l}\text { de onde tiramos } \\
\text { nosso sustento }\end{array}$} & & \multirow[t]{2}{*}{ único } & $\begin{array}{l}\text { ponto } \\
\text { positivo } \\
\text { dessa } \\
\text { construção é } \\
\text { que vai haver } \\
\text { mais } \\
\text { empregos e } \\
\text { mais lazer } \\
\text { para os } \\
\text { cidadãos }\end{array}$ \\
\hline & $\begin{array}{l}\text { Você sempre } \\
\text { tem comida }\end{array}$ & $\begin{array}{l}\text { Pense bem } \\
\text { antes de fazer } \\
\text { esse } \\
\text { condomínio. }\end{array}$ & & & & $\begin{array}{l}\text { mas pense } \\
\text { nas pessoas } \\
\text { que não têm } \\
\text { dinheiro para } \\
\text { ter um café- } \\
\text { da-manhã, } \\
\text { um almoço } \\
\text { ou um jantar } \\
\text { decente. }\end{array}$ \\
\hline & $\begin{array}{c}\text { Dado } \\
\text { (dado que....) }\end{array}$ & Conclusão & $\begin{array}{l}\text { Garantia } \\
\text { (já que...) }\end{array}$ & $\begin{array}{l}\text { Apoio (por } \\
\text { conta de...) }\end{array}$ & $\begin{array}{l}\text { Qualifica- } \\
\text { dor }\end{array}$ & $\begin{array}{c}\text { Refutador } \\
\text { (a menos } \\
\text { que...) }\end{array}$ \\
\hline \multirow[t]{3}{*}{$\mathrm{CC} 1$} & $\begin{array}{l}\text { gostaríamos de } \\
\text { estabelecer } \\
\text { nossas } \\
\text { opiniões sobre } \\
\text { as novas } \\
\text { construções da } \\
\text { cidade }\end{array}$ & \multirow[t]{3}{*}{$\begin{array}{l}\text { nós gostaríamos } \\
\text { que construa o } \\
\text { condomínio }\end{array}$} & & & & \multirow[t]{3}{*}{$\begin{array}{l}\text { mas não } \\
\text { desmatando } \\
\text { toda a } \\
\text { floresta }\end{array}$} \\
\hline & $\begin{array}{l}\text { Nossas } \\
\text { opiniões } \\
\text { negativas são: } \\
\text { O desmata- } \\
\text { mento das } \\
\text { florestas } \\
\end{array}$ & & $\begin{array}{l}\text { isso causa um } \\
\text { grande aumento } \\
\text { do clima e as } \\
\text { pessoas terão } \\
\text { mais custos } \\
\text { com impostos }\end{array}$ & & & \\
\hline & $\begin{array}{l}\text { um dos pontos } \\
\text { positivos } \\
\text { é o aumento do } \\
\text { comércio }\end{array}$ & & $\begin{array}{l}\text { mais lazer } \\
\text { para os } \\
\text { moradores e os } \\
\text { comerciantes } \\
\text { vão lucrar } \\
\text { muito }\end{array}$ & & & \\
\hline
\end{tabular}




\begin{tabular}{|c|c|c|c|c|c|c|}
\hline & $\begin{array}{c}\text { Dado } \\
\text { (dado que....) }\end{array}$ & Conclusão & $\begin{array}{l}\text { Garantia } \\
\text { (já que...) }\end{array}$ & $\begin{array}{l}\text { Apoio (por } \\
\text { conta de...) }\end{array}$ & $\begin{array}{l}\text { Qualifica- } \\
\text { dor }\end{array}$ & $\begin{array}{c}\text { Refutador } \\
\text { (a menos } \\
\text { que...) }\end{array}$ \\
\hline \multirow[t]{5}{*}{$\mathrm{CC} 2$} & $\begin{array}{l}\text { listamos } \\
\text { pontos } \\
\text { positivos e } \\
\text { negativos da } \\
\text { construção do } \\
\text { condomínio }\end{array}$ & & & & & \\
\hline & $\begin{array}{l}\text { Os pontos } \\
\text { negativos são } \\
\text { a área } \\
\text { desmatada }\end{array}$ & $\begin{array}{l}\text { deixando eles } \\
\text { sem abrigo e } \\
\text { sem comida }\end{array}$ & $\begin{array}{l}\text { que fará falta } \\
\text { para os } \\
\text { animais }\end{array}$ & & & \\
\hline & & & & & & $\begin{array}{l}\text { E por outro } \\
\text { lado, terá } \\
\text { mais lazer } \\
\text { para os } \\
\text { humanos, } \\
\text { gerando mais } \\
\text { empregos. }\end{array}$ \\
\hline & $\begin{array}{l}\text { É uma decisão } \\
\text { difícil para nós }\end{array}$ & $\begin{array}{l}\text { por isso } \\
\text { queremos que } \\
\text { escolha a } \\
\text { melhor opção }\end{array}$ & $\begin{array}{l}\text { Caso faça o } \\
\text { condomínio } \\
\text { esperamos que } \\
\text { pense na mata } \\
\text { e nos animais }\end{array}$ & & & \\
\hline & $\begin{array}{c}\text { Dado } \\
\text { (dado que....) }\end{array}$ & Conclusão & $\begin{array}{l}\text { Garantia } \\
\text { (já que....) }\end{array}$ & $\begin{array}{l}\text { Apoio (por } \\
\text { conta de...) }\end{array}$ & $\begin{array}{l}\text { Qualifica } \\
\text {-dor }\end{array}$ & $\begin{array}{c}\text { Refutador } \\
\text { (a menos } \\
\text { que...) }\end{array}$ \\
\hline \multirow[t]{2}{*}{ CC3 } & $\begin{array}{l}\text { nós do } \\
\text { comércio } \\
\text { observamos e } \\
\text { analisamos sua } \\
\text { ideia de } \\
\text { expandir a } \\
\text { cidade e o } \\
\text { condomínio }\end{array}$ & $\begin{array}{l}\text { A sua ideia será } \\
\text { apoiada por nós }\end{array}$ & & & & $\begin{array}{l}\text { mesmo } \\
\text { sendo } \\
\text { péssima ideia } \\
\text { em relação } \\
\text { ao meio } \\
\text { ambiente e } \\
\text { ao clima }\end{array}$ \\
\hline & $\begin{array}{c}\text { Dado } \\
\text { (dado que...) }\end{array}$ & Conclusão & $\begin{array}{l}\text { Garantia } \\
\text { (já que...) }\end{array}$ & $\begin{array}{l}\text { Apoio (por } \\
\text { conta de...) }\end{array}$ & $\begin{array}{l}\text { Qualifica- } \\
\text { dor }\end{array}$ & $\begin{array}{c}\text { Refutador } \\
\text { (a menos } \\
\text { que...) }\end{array}$ \\
\hline PE1 & $\begin{array}{l}\text { Há mais } \\
\text { pontos } \\
\text { positivos do } \\
\text { que negativos }\end{array}$ & & $\begin{array}{l}\text { pois os } \\
\text { negativos } \\
\text { prejudicam } \\
\text { mais a } \\
\text { natureza }\end{array}$ & & & \\
\hline
\end{tabular}




\begin{tabular}{|c|c|c|c|c|c|c|}
\hline & $\begin{array}{l}\text { Os pontos } \\
\text { positivos são: } \\
\text { conforto, } \\
\text { lazer para a } \\
\text { comunidade, } \\
\text { (...) tem mais } \\
\text { comunicação } \\
\text { entre pessoas }\end{array}$ & & & & & \\
\hline & $\begin{array}{l}\text { pontos } \\
\text { negativos são: } \\
\text { o desmata- } \\
\text { mento com } \\
\text { parte da } \\
\text { floresta }\end{array}$ & & $\begin{array}{l}\text { que causa o } \\
\text { aquecimento } \\
\text { global } \\
\text { (causando } \\
\text { enchentes e } \\
\text { essas coisas) e } \\
\text { tem mais gastos } \\
\text { de água } \\
\end{array}$ & $\begin{array}{l}\text { Aquecimento } \\
\text { global }\end{array}$ & & \\
\hline & & $\begin{array}{l}\text { Por isso } \\
\text { estamos contra } \\
\text { a construção do } \\
\text { condomínio }\end{array}$ & & & & \\
\hline & $\begin{array}{c}\text { Dado } \\
\text { (dado que...) }\end{array}$ & Conclusão & $\begin{array}{l}\text { Garantia } \\
\text { (já que....) }\end{array}$ & $\begin{array}{l}\text { Apoio (por } \\
\text { conta de...) }\end{array}$ & $\begin{array}{l}\text { Qualifica- } \\
\text { dor }\end{array}$ & $\begin{array}{c}\text { Refutador } \\
\text { (a menos } \\
\text { que...) }\end{array}$ \\
\hline PE2 & $\begin{array}{l}\text { se decidirem } \\
\text { construir um } \\
\text { condomínio } \\
\text { em nossa } \\
\text { cidade }\end{array}$ & $\begin{array}{l}\text { teríamos mais } \\
\text { doenças e as } \\
\text { pessoas } \\
\text { morreriam mais } \\
\text { cedo }\end{array}$ & & & & $\begin{array}{l}\text { Mas, se } \\
\text { construir } \\
\text { teremos um } \\
\text { conforto } \\
\text { melhor e } \\
\text { conheceríam } \\
\text { os mais } \\
\text { pessoas }\end{array}$ \\
\hline & & & $\begin{array}{l}\text { o ar ficaria } \\
\text { impuro }\end{array}$ & & & $\begin{array}{l}\text { Mas } \\
\text { teríamos } \\
\text { pragas }\end{array}$ \\
\hline & & $\begin{array}{l}\text { assim atrairiam } \\
\text { mais bandidos, } \\
\text { levando a mais } \\
\text { assaltos }\end{array}$ & $\begin{array}{l}\text { Seria mais } \\
\text { reconhecida } \\
\text { pelo dinheiro }\end{array}$ & & & $\begin{array}{l}\text { Mas, } \\
\text { prefeito, } \\
\text { como as } \\
\text { pessoas irão } \\
\text { pagar o } \\
\text { condomínio? }\end{array}$ \\
\hline & & $\begin{array}{l}\text { Esperamos seu } \\
\text { retorno e que } \\
\text { faça a coisa } \\
\text { certa! }\end{array}$ & & & & \\
\hline
\end{tabular}




\begin{tabular}{|c|c|c|c|c|c|c|}
\hline & $\begin{array}{c}\text { Dado } \\
\text { (dado que....) }\end{array}$ & Conclusão & $\begin{array}{l}\text { Garantia } \\
\text { (já que...) }\end{array}$ & $\begin{array}{l}\text { Apoio (por } \\
\text { conta de...) }\end{array}$ & $\begin{array}{l}\text { Qualifica- } \\
\text { dor }\end{array}$ & $\begin{array}{c}\text { Refutador } \\
\text { (a menos } \\
\text { que...) } \\
\end{array}$ \\
\hline \multirow[t]{3}{*}{ PE3 } & $\begin{array}{l}\text { sua construção, } \\
\text { por um lado, } \\
\text { pode nos } \\
\text { ajudar }\end{array}$ & $\begin{array}{l}\text { nós nos } \\
\text { preocupamos } \\
\text { com isso }\end{array}$ & $\begin{array}{l}\text { melhorando } \\
\text { nossa condição } \\
\text { de vida }\end{array}$ & & & \begin{tabular}{|l} 
mas por \\
outro lado \\
ela iria \\
prejudicar \\
muito o \\
meio \\
ambiente \\
causando \\
muitos \\
danos a ele \\
\end{tabular} \\
\hline & $\begin{array}{l}\text { Queremos } \\
\text { morar em um } \\
\text { lugar melhor, } \\
\text { mas para isso }\end{array}$ & $\begin{array}{l}\text { é preciso que } \\
\text { você não } \\
\text { prejudique o } \\
\text { meio ambiente } \\
\text { para não } \\
\text { ficarmos tão } \\
\text { preocupados. }\end{array}$ & & & & \\
\hline & $\begin{array}{c}\text { Dado } \\
\text { (dado que....) }\end{array}$ & Conclusão & $\begin{array}{l}\text { Garantia } \\
\text { (já que....) }\end{array}$ & $\begin{array}{l}\text { Apoio (por } \\
\text { conta de...) }\end{array}$ & $\begin{array}{c}\text { Qualificad } \\
\text { or }\end{array}$ & $\begin{array}{l}\text { Refutador } \\
\text { (a menos } \\
\text { que...) }\end{array}$ \\
\hline \multirow[t]{3}{*}{ MA1 } & $\begin{array}{l}\text { em relação a } \\
\text { sua proposta, } \\
\text { já decidimos. } \\
\text { Nós } \\
\text { gostaríamos } \\
\text { que a floresta } \\
\text { ficasse em seu } \\
\text { lugar }\end{array}$ & & $\begin{array}{l}\text { porque se nós } \\
\text { destruirmos } \\
\text { essa mata } \\
\text { teremos mais } \\
\text { espaço para o } \\
\text { lazer, para se } \\
\text { divertir, } \\
\text { estudar, entre } \\
\text { outros }\end{array}$ & & & \multirow{3}{*}{$\begin{array}{l}\text { Mas também } \\
\text { há um lado } \\
\text { ruim, } \\
\text { porque } \\
\text { iremos } \\
\text { destruir o } \\
\text { meio } \\
\text { ambiente e o } \\
\text { habitat dos } \\
\text { animais, } \\
\text { para } \\
\text { fazermos } \\
\text { uma coisa } \\
\text { que já temos }\end{array}$} \\
\hline & & $\begin{array}{l}\text { Nossa decisão é } \\
\text { não destruir } \\
\text { essa mata }\end{array}$ & $\begin{array}{l}\text { porque nós } \\
\text { precisamos dela } \\
\text { para sobreviver }\end{array}$ & & & \\
\hline & $\begin{array}{l}\text { Se nós não } \\
\text { destruirmos }\end{array}$ & $\begin{array}{l}\text { estaremos } \\
\text { ajudando a } \\
\text { preservar o } \\
\text { meio ambiente } \\
\text { e o habitat dos } \\
\text { animais }\end{array}$ & & & & \\
\hline
\end{tabular}




\begin{tabular}{|c|c|c|c|c|c|c|}
\hline & $\begin{array}{c}\text { Dado } \\
\text { (dado que....) }\end{array}$ & Conclusão & $\begin{array}{l}\text { Garantia } \\
\text { (já que...) }\end{array}$ & $\begin{array}{l}\text { Apoio (por } \\
\text { conta de...) }\end{array}$ & $\begin{array}{c}\text { Qualificad } \\
\text { or }\end{array}$ & $\begin{array}{l}\text { Refutador } \\
\text { (a menos } \\
\text { que....) }\end{array}$ \\
\hline \multirow[t]{4}{*}{ MA2 } & $\begin{array}{l}\text { Embora a } \\
\text { nossa cidade } \\
\text { seja pequena e } \\
\text { precise de } \\
\text { prédios, a } \\
\text { floresta é } \\
\text { ainda mais } \\
\text { importante }\end{array}$ & $\begin{array}{l}\text { Teríamos mais } \\
\text { um lugar para } \\
\text { morar, mais } \\
\text { lazer }\end{array}$ & $\begin{array}{l}\text { pois nem todo o } \\
\text { lugar tem } \\
\text { floresta }\end{array}$ & & & \\
\hline & & $\begin{array}{l}\text { nós achamos } \\
\text { que desmatar } \\
\text { uma parte da } \\
\text { floresta só } \\
\text { para construir } \\
\text { um prédio já se } \\
\text { torna um } \\
\text { exagero }\end{array}$ & & & & \\
\hline & & & $\begin{array}{l}\text { as árvores são } \\
\text { fundamentais } \\
\text { para a nossa } \\
\text { vida }\end{array}$ & $\begin{array}{l}\text { pois elas } \\
\text { (árvores) } \\
\text { absorvem a } \\
\text { fumaça e liberam } \\
\text { o ar limpo } \\
\text { (fotossíntese) }\end{array}$ & $\begin{array}{l}\text { E como } \\
\text { sabem }\end{array}$ & $\begin{array}{l}\text { mas a } \\
\text { consequência } \\
\text { que teremos } \\
\text { é que } \\
\text { desmatarem } \\
\text { os árvores, } \\
\text { mata, etc... }\end{array}$ \\
\hline & $\begin{array}{c}\text { Dado } \\
\text { (dado que....) }\end{array}$ & Conclusão & $\begin{array}{l}\text { Garantia } \\
\text { (já que....) }\end{array}$ & $\begin{array}{l}\text { Apoio (por } \\
\text { conta de...) }\end{array}$ & $\begin{array}{l}\text { Qualifica- } \\
\text { dor }\end{array}$ & $\begin{array}{c}\text { Refutador } \\
\text { (a menos } \\
\text { que...) }\end{array}$ \\
\hline MA3 & $\begin{array}{l}\text { nós, } \\
\text { ambientalistas } \\
\text { da cidade, } \\
\text { estamos } \\
\text { protestando } \\
\text { sobre o } \\
\text { desmata- } \\
\text { mento da } \\
\text { cidade para a } \\
\text { construção de } \\
\text { um } \\
\text { condomínio }\end{array}$ & & $\begin{array}{l}\text { porque há } \\
\text { vários pontos } \\
\text { negativos: }\end{array}$ & & & \\
\hline
\end{tabular}




\begin{tabular}{|c|c|c|c|c|c|c|}
\hline & & $\begin{array}{l}\text { o ar será mais } \\
\text { poluído }\end{array}$ & $\begin{array}{l}\text { pois não terá } \\
\text { mais árvores }\end{array}$ & & & \\
\hline & & & $\begin{array}{l}\text { os animais que } \\
\text { moram na } \\
\text { floresta, } \\
\text { perderão suas } \\
\text { casas }\end{array}$ & & & \\
\hline & & $\begin{array}{l}\text { Esperamos que } \\
\text { o senhor tome a } \\
\text { decisão certa }\end{array}$ & & $\begin{array}{l}\text { se não existirem } \\
\text { plantas, não } \\
\text { existirão } \\
\text { herbívoros, não } \\
\text { existirão } \\
\text { carnívoros e se } \\
\text { não existirão } \\
\text { carnívoros e } \\
\text { herbívoros, não } \\
\text { existirá mais } \\
\text { vida (cadeia } \\
\text { alimentar) }\end{array}$ & & $\begin{array}{l}\text { Mas, } \\
\text { também há } \\
\text { vários pontos } \\
\text { positivos: a } \\
\text { moradia das } \\
\text { pessoas será } \\
\text { melhor, elas } \\
\text { terão } \\
\text { melhores } \\
\text { condições de } \\
\text { vida }\end{array}$ \\
\hline & $\begin{array}{c}\text { Dado } \\
\text { (dado que...) }\end{array}$ & Conclusão & $\begin{array}{l}\text { Garantia } \\
\text { (já que....) }\end{array}$ & $\begin{array}{l}\text { Apoio (por } \\
\text { conta de...) }\end{array}$ & $\begin{array}{l}\text { Qualifica- } \\
\text { dor }\end{array}$ & $\begin{array}{c}\text { Refutador } \\
\text { (a menos } \\
\text { que...) } \\
\end{array}$ \\
\hline TR1 & $\begin{array}{l}\text { nós } \\
\text { trabalhadores } \\
\text { da construtora } \\
\text { de } \\
\text { condomínios, } \\
\text { poderíamos } \\
\text { desmatar uma } \\
\text { pequena parte } \\
\text { da floresta } \\
\text { para construir } \\
\text { o condomínio } \\
\text { que ocupe } \\
\text { menos espaço } \\
\text { da floresta, } \\
\text { por um espaço } \\
\text { razoável }\end{array}$ & $\begin{array}{l}\text { Tudo o que } \\
\text { desmatarmos } \\
\text { será reposto } \\
\text { em outro lugar }\end{array}$ & $\begin{array}{l}\text { Se não } \\
\text { construirmos o } \\
\text { condomínio, } \\
\text { não teremos } \\
\text { salários, isso } \\
\text { afetaria as } \\
\text { ações da } \\
\text { empresa. }\end{array}$ & & & \\
\hline
\end{tabular}




\begin{tabular}{|c|c|c|c|c|c|c|}
\hline & $\begin{array}{c}\text { Dado } \\
\text { (dado que...) }\end{array}$ & Conclusão & $\begin{array}{l}\text { Garantia } \\
\text { (já que...) }\end{array}$ & $\begin{array}{l}\text { Apoio (por } \\
\text { conta de...) }\end{array}$ & $\begin{array}{l}\text { Qualifica- } \\
\text { dor }\end{array}$ & $\begin{array}{l}\text { Refutador } \\
\text { (a menos } \\
\text { que...) }\end{array}$ \\
\hline \multirow[t]{6}{*}{ TR2 } & \multirow[t]{5}{*}{$\begin{array}{l}\text { Como } \\
\text { trabalhadores } \\
\text { da obra nova, } \\
\text { dizemos que } \\
\text { essa obra só } \\
\text { trará coisas } \\
\text { ruins para } \\
\text { nossa cidade }\end{array}$} & & $\begin{array}{l}\text { Já os pontos } \\
\text { negativos são } \\
\text { muitos: }\end{array}$ & & & $\begin{array}{l}\text { os únicos } \\
\text { pontos } \\
\text { positivos } \\
\text { são: teria } \\
\text { mais } \\
\text { moradia, } \\
\text { valorizaria a } \\
\text { região e } \\
\text { teriam mais } \\
\text { empregos }\end{array}$ \\
\hline & & & $\begin{array}{l}\text { acabariam } \\
\text { com todo o } \\
\text { verde }\end{array}$ & $\begin{array}{l}\text { ou seja, } \\
\text { desmatariam }\end{array}$ & & \\
\hline & & & $\begin{array}{l}\text { gastaria mais } \\
\text { água, }\end{array}$ & $\begin{array}{l}\text { por causa de } \\
\text { eletricidade }\end{array}$ & & \\
\hline & & & $\begin{array}{l}\text { e também como } \\
\text { as árvores não } \\
\text { estariam mais } \\
\text { lá }\end{array}$ & $\begin{array}{l}\text { não daria para } \\
\text { transformar gás } \\
\text { carbônico em ar } \\
\text { (oxigênio) } \\
\text { (fotossíntese) }\end{array}$ & & \\
\hline & & $\begin{array}{l}\text { Realmente para } \\
\text { nós, } \\
\text { trabalhadores, } \\
\text { seria bom por } \\
\text { causa do salário }\end{array}$ & & & & $\begin{array}{l}\text { mas } \\
\text { pensando na } \\
\text { população } \\
\text { da cidade, } \\
\text { não valeria } \\
\text { a pena }\end{array}$ \\
\hline & $\begin{array}{c}\text { Dado } \\
\text { (dado que...) }\end{array}$ & Conclusão & $\begin{array}{l}\text { Garantia } \\
\text { (já que...) }\end{array}$ & $\begin{array}{l}\text { Apoio (por } \\
\text { conta de...) }\end{array}$ & $\begin{array}{l}\text { Qualifica- } \\
\text { dor }\end{array}$ & $\begin{array}{c}\text { Refutador } \\
\text { (a menos } \\
\text { que...) }\end{array}$ \\
\hline TR3 & $\begin{array}{l}\text { estamos de } \\
\text { parcial acordo } \\
\text { com sua } \\
\text { respeitável } \\
\text { proposta }\end{array}$ & $\begin{array}{l}\text { Então os } \\
\text { moradores } \\
\text { poderão } \\
\text { interagir } \\
\text { diretamente } \\
\text { com a natureza. } \\
\text { O projeto levará } \\
\text { seis meses para } \\
\text { ser completo. }\end{array}$ & $\begin{array}{l}\text { Nossa condição } \\
\text { é que possamos } \\
\text { incluir dentro } \\
\text { do condomínio } \\
\text { (...) uma área } \\
\text { das árvores } \\
\text { que } \\
\text { replantaremos } \\
\text { para } \\
\text { compensar o } \\
\text { desmatamento. }\end{array}$ & & & \\
\hline
\end{tabular}

Tabela 2 - Categorização das respostas dos alunos segundo o padrão de argumento de

Toulmin (2006) 


\subsubsection{Discussão sobre os elementos presentes nos argumentos dos alunos}

A categorização dos elementos dos argumentos presentes nas respostas dos alunos está representada na tabela 2. Inicio a análise dos dados observando os conceitos científicos e as mensagens que o filme transmite e que estão presentes nas respostas dos alunos. Essas informações são muito importantes para perceber o que mais chama a atenção dos estudantes nesse recurso apresentado.

Diversos conceitos contidos no filme aparecem nas respostas dos alunos, como já fora discutido anteriormente, tais como: habitat, extinção, hibernação, cadeia alimentar, animais como pragas naturais, animais humanizados, alimentação dos animais, lazer para os seres humanos. Dessa maneira, percebo como as mensagens veiculadas pelo filme são importantes e centrais na realização da tarefa.

Das dezoito respostas dos alunos, apenas um grupo (CC3) não construiu um argumento que pode ser caracterizado como formalmente válido, uma vez que não apresenta os elementos essenciais de um argumento: dado, garantia e conclusão. O grupo CC3 apresenta sua opinião sobre a construção ("sua ideia será apoiada por nós"), porém não apresenta nenhuma justificativa para a sua decisão e apenas um refutador ("mesmo sendo péssima ideia em relação ao meio ambiente e ao clima.") para sua conclusão. Percebo que, essa dificuldade na tomada de decisão do grupo, se deve ao setor da sociedade que estão representando, os comerciantes da cidade. Eles deveriam considerar importante a construção do condomínio, porém não conseguem fazê-lo, de maneira decisiva, por causa da mensagem que o filme transmite (os seres vivos dependem da floresta para viver).

Os dados (D) do argumento são os fundamentos para a alegação, a partir deles se constrói a argumentação. Nas dezoito respostas dos alunos, foram identificados trinta dados, dos quais doze (40\%) continham informações presentes no filme, dez grupos (AN3, CM1, CM2, CC1, CC2, PE1, MA1, MA2, MA3 e TR1) utilizaram como dados os conceitos presentes no filme, o que indica que os alunos utilizaram como fundamentos na construção de suas respostas as mensagens do filme trabalhado.

A conclusão do argumento (C) é a alegação em si, no caso da questão proposta é a decisão que o grupo pretende tomar. Nove grupos (CM1, CM2, CM3, CC2, PE2, PE3, 
MA1, MA2 e TR1) utilizaram em suas conclusões conceitos presentes no filme, ressaltando a importância das mensagens apresentadas pelo recurso.

O elemento do argumento que indica a relação entre o dado apresentado e a conclusão é a garantia (W). As garantias são afirmações gerais, hipotéticas, que servem como pontes dos dados às conclusões e têm de ser estabelecidas de modo muito diferente dos fatos que apresentamos como dados (Toulmin, 2006). Um argumento só é formalmente válido se apresentar esses três elementos (dado, garantia e conclusão). Nas respostas dos alunos, a garantia foi o elemento do argumento que mais apresentou conceitos e mensagens expressas no filme (das 36 garantias citadas, 22 estavam relacionadas ao filme, ou seja, aproximadamente, 60\%). Doze grupos (AN1, AN2, AN3, CM1, CM2, CC1, CC2, PE1, MA1, MA3, TR2 e TR3) utilizaram as mensagens do filme para justificar suas respostas, o que aponta para a grande relevância que os alunos dão às mensagens apresentadas no filme na construção de suas respostas.

O apoio (B) é campo-dependente, ou seja, ele faz sentido dentro de um campo teórico baseado em uma lei (jurídica ou científica). O apoio é necessário para estabelecer nossas garantias, o apoio para as garantias pode ser expresso na forma de afirmações categóricas de fato, como também podem ser expressos os dados invocados em suporte direto para nossas conclusões (Toulmin, 2006). O apoio empresta autoridade às nossas garantias. Muitas vezes, o apoio pode estar implícito, nesses casos, eles não foram considerados nesta análise (dez respostas não apresentaram o apoio à garantia). Quatro respostas (AN1, CM2, MA3 e TR2) apresentaram como apoio os conceitos e mensagens apresentados no filme, o que mostra a importância das informações que o filme se propõe a transmitir, já que o apoio é o campo teórico em que a garantia se sustenta. O grupo CM2 mencionou a extinção dos animais e o período de hibernação, os grupos AN1 e AM3 mencionaram o conceito de cadeia alimentar e o grupo TR2 mencionou o desmatamento. Outros conceitos são apresentados como apoio à garantia, como o conceito de fotossíntese e de aquecimento global, porém esses conceitos não são trabalhados no filme, por isso não foram considerados nessa análise dos elementos dos argumentos.

Os refutadores $(\mathrm{R})$ invalidam a passagem dos dados às garantias, as condições de refutação indicam circunstâncias nas quais têm de se deixar de lado a autoridade geral da 
garantia (Toulmin, 2006). Nesse caso, nove respostas (CM1, CM3, CC1, CC2, PE2, PE3, MA1, MA2 e TR2), ou seja, 50\% dos grupos apresentam como refutação as informações presentes no filme, o que mostra o caráter ambíguo em suas respostas. Categorizei como refutador, as informações que vão contra a conclusão. Os grupos não conseguem tomar posição em relação à questão levantada, o que reflete na construção de seus argumentos. Eles defendem uma posição, porém apresentam pontos contrários aos seus próprios posicionamentos, para defenderem outra opinião. Em muitas respostas, apesar de trazerem diversos elementos, fica difícil interpretar que decisão eles tomam a respeito da construção do condomínio. Analiso essa ambiguidade à própria questão proposta, já que a questão pede aos alunos que apresentem pontos positivos e negativos à construção do condomínio, fazendo-os pensarem nos dois pontos de vista e tendo que expressá-los.

Os qualificadores (Q) indicam a força conferida pela garantia. Eles podem ser identificados como as expressões "provavelmente" e "possivelmente". Os conceitos e mensagens do filme não foram usados como qualificadores em nenhuma resposta, devido à natureza dos próprios qualificadores.

\subsection{Identificação dos padrões morais e valores presentes nas respostas dos alunos}

Na tabela 3, identifico os padrões morais e valores presentes nas respostas dos alunos, sublinho todas as vezes que o texto apresenta uma opinião pessoal, por um juízo de valor ou um padrão moral. Estes elementos, quando apareceram no filme, foram identificados por mim anteriormente. Essa identificação permite fazer reflexões sobre minha pergunta de investigação, para perceber que mensagens no filme são mais significativas aos alunos e de que maneira os alunos utilizam-nas na construção de suas argumentações. 


\begin{tabular}{|c|c|c|}
\hline $\begin{array}{l}\text { Grupo } \\
\text { de } \\
\text { alunos }\end{array}$ & $\begin{array}{c}\text { Respostas dos alunos apresentando os padrões } \\
\text { morais e valores ( } \underline{\text { sublinhado) }}\end{array}$ & Padrões morais e valores \\
\hline AN1 & $\begin{array}{l}\text { Prefeito, nós em nome de todos os animais da } \\
\text { floresta, achamos pontos negativos e positivos em } \\
\text { construir o condomínio. Os pontos negativos são: } \\
\text { vocês vão nos matar, deixando-nos sem água, lar e } \\
\text { comida, a cadeia alimentar irá se prejudicar e nós } \\
\text { entraremos em extinção porque o ciclo da cadeia } \\
\text { alimentar irá mudar prejudicando nossas vidas e } \\
\underline{\text { dos predadores, para você isso não é nada, mas para }} \\
\text { nós isso é muito importante, também podemos } \\
\text { levar choques com fios elétricos ou sermos pegos } \\
\text { por armadilhas. Os pontos positivos são: será mais } \\
\text { fácil arranjar comida, no inverno podemos reutilizar } \\
\text { as roupas que vocês jogam fora. Chegando a esse } \\
\text { ponto nós achamos que será melhor não construir o } \\
\underline{\text { condomínio, porque irá nos prejudicar e prejudicar }} \\
\text { vocês. }\end{array}$ & $\begin{array}{l}\text { - } \quad \text { Raciocínio } \\
\text { Consequencialista } \\
\text { - Valor à vida } \\
\text { - } \underline{\text { Respeito ao }} \\
\underline{\text { ambiente }}\end{array}$ \\
\hline AN2 & $\begin{array}{l}\text { Caro prefeito, nós, animais da floresta, estamos } \\
\text { mandando uma carta para falar sobre os horríveis } \\
\text { desmatamentos e poluições em nossa casa, floresta. } \\
\text { Nós exigimos nosso espaço! Vamos escrever uma } \\
\text { lista com tudo o que precisamos: comida, água, } \\
\text { árvores. Com isso, nós comunicamos que podem } \\
\text { matar apenas } 1 / 5 \text { de nossa floresta. Obrigado. }\end{array}$ & $\begin{array}{l}\text { - Moral Emotiva. } \\
\text { - } \underline{\text { Respeito ao meio }} \\
\underline{\text { ambiente }} \\
\text { - Questões sociais e } \\
\text { políticas (valor à moradia) }\end{array}$ \\
\hline AN3 & $\begin{array}{l}\text { Caro prefeito, nós, animais da floresta, não } \\
\text { concordamos com o desmatamento de nossa casa, } \\
\text { porque primeiro não vamos ter onde morar, } \\
\text { segundo nós não sobreviveremos sem ter onde }\end{array}$ & $\begin{array}{l}\text { - } \quad \text { Raciocínio moral } \\
\text { consequencialista } \\
\text { - Valor à vida } \\
\text { - Questões sociais e }\end{array}$ \\
\hline
\end{tabular}




\begin{tabular}{|c|c|c|}
\hline & $\begin{array}{l}\text { morar, terceiro o ar ficará mais poluído, quarto você } \\
\text { acha que vale a pena acabar com a floresta só para } \\
\text { construir um condomínio? A fotossíntese não irá } \\
\text { existir na cidade. Por favor, esperamos que tome a } \\
\text { melhor decisão. }\end{array}$ & \begin{tabular}{l}
\multicolumn{3}{l}{ políticas (valor à moradia) } \\
- $\underline{\text { Respeito ao meio }}$ \\
$\underline{\text { ambiente }}$
\end{tabular} \\
\hline CM1 & $\begin{array}{l}\text { Caro prefeito, não gostamos muito dessa sua ideia. } \\
\text { Tudo bem, haverá mais lugares de lazer, de trabalho } \\
\text { para nós e também mais moradias, mas também vão } \\
\text { causar mortes, não teremos mais sustentação, } \\
\text { causará um desastre na floresta, estragará a moradia } \\
\text { dos animais, acabará com os nossos recursos } \\
\text { naturais e extinção de alguns animais. Mas, se o } \\
\text { senhor vai construir esse tal de condomínio, deve } \\
\text { deixar um espaço para os animais, pois esse é o } \\
\text { habitat deles, também deve deixar recursos para } \\
\text { eles e para nós. Prefeito, se você gostou de nossa } \\
\text { ideia, então demore um bom tempo, para } \\
\underline{\text { conseguirmos outro habitat para os animais e }} \\
\underline{\text { também outro lugar para que retirássemos os nossos }} \\
\underline{\text { sustentos. Há mais um pedido: se você construísse }} \\
\underline{\text { mais algumas florestas (já que só tem essa }} \\
\text { pequenina), aí sim você poderia fazer o } \\
\underline{\text { condomínio, pois teríamos outros lugares melhores. }} \\
\text { Obrigado por sua consideração. Esperamos que } \\
\text { goste de nossas ideias e as atenda. }\end{array}$ & $\begin{array}{l}\text { - Questões sociais e } \\
\text { políticas (valor à cultura, à } \\
\underline{\text { moradia, ao coletivo e aos }} \\
\underline{\text { recursos financeiros) }} \\
\text { - } \underline{\text { Valor à vida }} \\
\text { - } \underline{\text { Respeito ao meio }} \\
\underline{\text { ambiente }} \\
\text { Raciocínio Moral } \\
\text { Consequencialista }\end{array}$ \\
\hline CM2 & $\begin{array}{l}\text { Caro prefeito, como moradores especializados em } \\
\text { Biologia um desmatamento feito para o aumento de } \\
\text { condomínios provoca reações na natureza, como, } \\
\text { por exemplo, invasões de procura de comida no } \\
\text { território urbano, por extinto próprio dos animais. }\end{array}$ & $\begin{array}{l}\text { - } \quad \text { Raciocínio } \\
\text { Consequencialista } \\
\text { Respeito ao meio } \\
\text { ambiente }\end{array}$ \\
\hline
\end{tabular}




\begin{tabular}{|c|c|c|}
\hline & $\begin{array}{l}\text { Por causa do período de hibernação, a gordura que } \\
\text { os animais armazenavam se foi. Por causa do } \\
\text { período da hibernação ocorrer durante muitos } \\
\text { meses, faz com que eles fiquem mais famintos do } \\
\text { que o normal. Provoca sujeira, pois os animais } \\
\text { vasculham as latas de lixo a procura de alimento. } \\
\underline{\text { Isso irrita um pouco os moradores o que fazem eles }} \\
\underline{\text { tomarem atitudes agressivas. Peço a todos que }} \\
\underline{\text { colaborem com os recursos ambientais. }} \\
\text { Agradecemos pela atenção. }\end{array}$ & \\
\hline CM3 & $\begin{array}{l}\text { Caro prefeito, nós não admitimos que você desmate } \\
\text { a floresta de onde tiramos nosso sustento. Nossa } \\
\text { sobrevivência depende dessa floresta. O único } \\
\text { ponto positivo dessa construção é que vai haver } \\
\text { mais empregos e mais lazer para os cidadãos. Você } \\
\text { sempre tem comida, mas pense nas pessoas que não } \\
\text { têm dinheiro para ter um café-da-manhã, um } \\
\text { almoço ou um jantar decente. Pense bem antes de } \\
\text { fazer esse condomínio. Agradecemos pela sua } \\
\text { atenção. }\end{array}$ & $\begin{array}{l}\text { - } \quad \text { Raciocínio Moral } \\
\text { Deontológico } \\
\text { - Valor à vida } \\
\text { - Questões sociais e } \\
\text { políticas (valor ao coletivo } \\
\underline{\text { e aos recursos financeiros) }} \\
\text { - } \underline{\text { Moral Emotiva }}\end{array}$ \\
\hline $\mathrm{CC} 1$ & $\begin{array}{l}\text { Caro prefeito, gostaríamos de estabelecer nossas } \\
\text { opiniões sobre as novas construções da cidade. } \\
\text { Nossas opiniões negativas são: O desmatamento } \\
\text { das florestas e isso causa um grande aumento do } \\
\text { clima e as pessoas terão mais custos com impostos. } \\
\text { Pontos positivos: um dos pontos positivos é o } \\
\text { aumento do comércio, mais lazer para os moradores } \\
\text { e os comerciantes vão lucrar muito. Muito obrigado } \\
\text { (a) pela sua atenção. Então, nós gostaríamos que } \\
\text { construa o condomínio, mas não desmatando toda a }\end{array}$ & 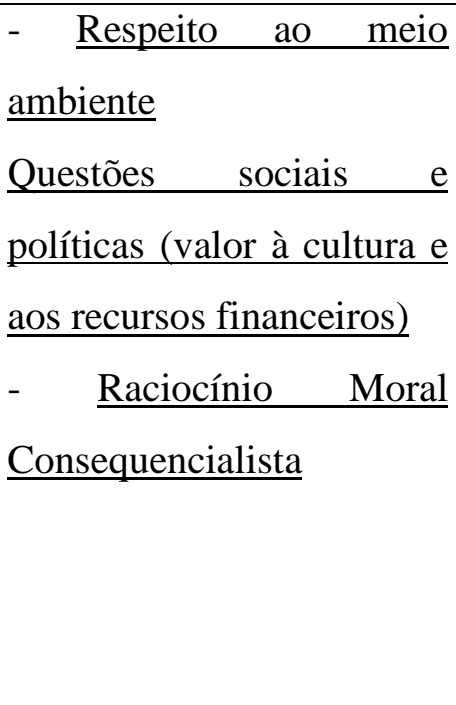 \\
\hline
\end{tabular}




\begin{tabular}{|c|c|c|}
\hline & resta. & \\
\hline $\mathrm{CC} 2$ & $\begin{array}{l}\text { Caro prefeito, listamos pontos positivos e negativos } \\
\text { da construção do condomínio. Os pontos negativos } \\
\underline{\text { são a área desmatada, que fará falta para os }} \\
\text { animais, deixando eles sem abrigo e sem comida. E } \\
\text { por outro lado, terá mais lazer para os humanos, } \\
\text { gerando mais empregos. É uma decisão difícil para } \\
\text { nós, por isso queremos que escolha a melhor opção. } \\
\text { Caso faça o condomínio esperamos que pense na } \\
\text { mata e nos animais. Aguardamos resposta. }\end{array}$ & $\begin{array}{l}\text { - } \quad \text { Raciocínio Moral } \\
\underline{\text { Deontológico }} \\
\text { - Questões sociais e } \\
\text { políticas (valor à moradia, } \\
\underline{\text { à cultura e aos recursos }} \\
\underline{\text { financeiros) }}\end{array}$ \\
\hline CC3 & $\begin{array}{l}\text { Caro prefeito, nós do comércio observamos e } \\
\text { analisamos sua ideia de expandir a cidade e o } \\
\text { condomínio. A sua ideia será apoiada por nós, } \\
\text { mesmo sendo péssima idéia em relação ao meio } \\
\text { ambiente e ao clima. }\end{array}$ & $\begin{array}{l}\text { - } \underline{\text { Moral Intuitiva }} \\
\text { - } \underline{\text { Respeito ao }} \\
\underline{\text { ambiente }}\end{array}$ \\
\hline PE1 & $\begin{array}{l}\text { Seu Prefeito, há mais pontos positivos do que } \\
\text { negativos, pois os negativos prejudicam mais a } \\
\text { natureza. Os pontos positivos são: conforto, lazer } \\
\text { para a comunidade, (...) tem mais comunicação } \\
\text { entre pessoas. E os pontos negativos são: o } \\
\text { desmatamento com parte da floresta que causa o } \\
\underline{\text { aquecimento global (causando enchentes e essas }} \\
\underline{\text { coisas) e tem mais gastos de água. Por isso estamos }} \\
\underline{\text { contra a construção do condomínio. }}\end{array}$ & 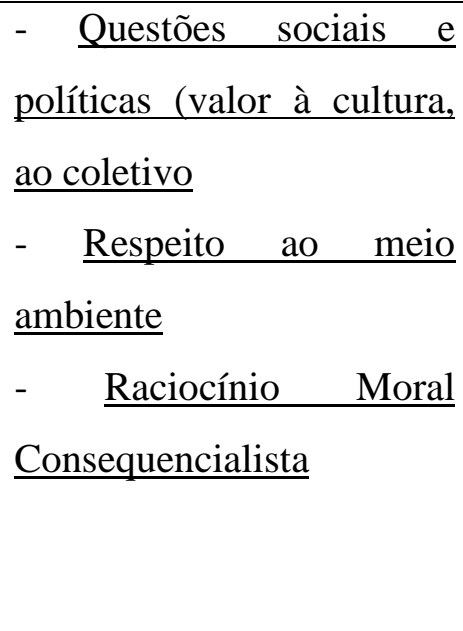 \\
\hline PE2 & $\begin{array}{l}\text { Cara Prefeitura, se decidirem construir um } \\
\text { condomínio em nossa cidade, teríamos mais } \\
\text { doenças e as pessoas morreriam mais cedo. Mas, se } \\
\text { construir teremos um conforto melhor e } \\
\text { conheceríamos mais pessoas. Mas teríamos pragas, } \\
\text { o ar ficaria impuro. Seria mais reconhecida pelo }\end{array}$ & $\begin{array}{l}\text { - Raciocínio Moral } \\
\text { Consequencialista } \\
\text { - Valor à vida } \\
\text { - Questões sociais e } \\
\text { políticas (valor ao } \\
\text { coletivo) }\end{array}$ \\
\hline
\end{tabular}




\begin{tabular}{|c|c|c|}
\hline & $\begin{array}{l}\text { dinheiro, assim atrairiam mais bandidos, levando a } \\
\text { mais assaltos. Mas, prefeito, como as pessoas irão } \\
\text { pagar o condomínio? Esperamos seu retorno e que } \\
\text { faça a coisa certa! }\end{array}$ & \\
\hline PE3 & $\begin{array}{l}\text { Prezado prefeito, sua construção, por um lado, pode } \\
\text { nos ajudar melhorando nossa condição de vida, mas } \\
\text { por outro lado ela iria prejudicar muito o meio } \\
\text { ambiente causando muitos danos a ele e nós nos } \\
\text { preocupamos com isso. Queremos morar em um } \\
\text { lugar melhor, mas para isso é preciso que você não } \\
\text { prejudique o meio ambiente para não ficarmos tão } \\
\text { preocupados. Obrigado! }\end{array}$ & 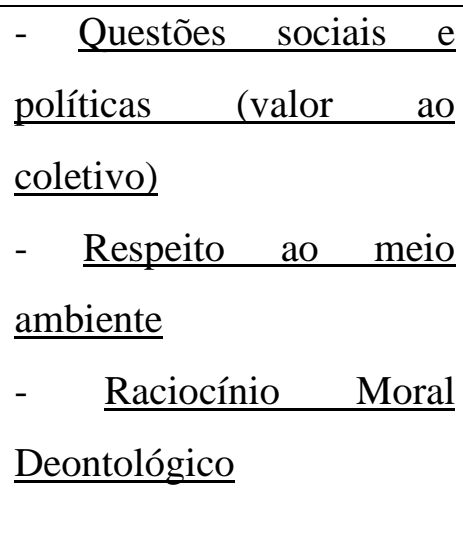 \\
\hline MA1 & $\begin{array}{l}\text { Caro prefeito, em relação a sua proposta, já } \\
\text { decidimos. Nós gostaríamos que a floresta ficasse } \\
\text { em seu lugar, porque se nós destruirmos essa mata } \\
\text { teremos mais espaço para o lazer, para se divertir, } \\
\text { estudar, entre outros. Mas também há um lado } \\
\text { ruim, porque iremos destruir o meio ambiente e o } \\
\text { habitat dos animais, para fazermos uma coisa que já } \\
\text { temos. Se nós não destruirmos, estaremos ajudando } \\
\text { a preservar o meio ambiente e o habitat dos } \\
\text { animais. Nossa decisão é não destruir essa mata, } \\
\text { porque nós precisamos dela para sobreviver. }\end{array}$ & $\begin{array}{l}\text { - Questões sociais e } \\
\text { políticas (valor à cultura, } \\
\text { ao coletivo e à moradia) } \\
\text { - } \underline{\text { Respeito ao meio }} \\
\underline{\text { ambiente }} \\
\text { - } \underline{\text { Raciocínio Moral }} \\
\underline{\text { Consequencialista }}\end{array}$ \\
\hline MA2 & $\begin{array}{l}\text { Caro prefeito, nós achamos que desmatar uma parte } \\
\text { da floresta só para construir um prédio já se torna } \\
\text { um exagero. Embora a nossa cidade seja pequena e } \\
\text { precise de prédios, a floresta é ainda mais } \\
\text { importante, pois nem todo o lugar tem floresta. } \\
\text { Teríamos mais um lugar para morar, mais lazer, } \\
\text { mas a consequência que teremos é que }\end{array}$ & 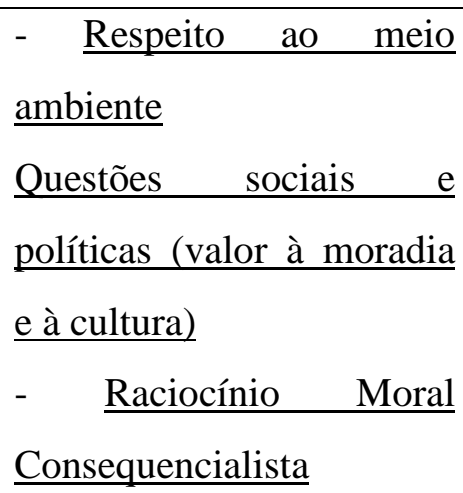 \\
\hline
\end{tabular}




\begin{tabular}{|c|c|c|}
\hline & $\begin{array}{l}\text { desmataremos árvores, mata, etc... E como sabem } \\
\text { as árvores são fundamentais para a nossa vida, pois } \\
\text { elas (árvores) absorvem a fumaça e liberam o ar } \\
\text { limpo. Aguardamos um retorno. }\end{array}$ & \\
\hline MA3 & $\begin{array}{l}\text { Caro Senhor Prefeito, nós, ambientalistas da cidade, } \\
\text { estamos protestando sobre o desmatamento da } \\
\text { cidade para a construção de um condomínio, } \\
\text { porque há vários pontos negativos: o ar será mais } \\
\text { poluído, pois não terá mais árvores, os animais que } \\
\text { moram na floresta, perderão suas casas, se não } \\
\text { existirem plantas, não existirão herbívoros, não } \\
\text { existirão carnívoros e se não existirão carnívoros e } \\
\text { herbívoros, não existirá mais vida. Mas, também há } \\
\text { vários pontos positivos: a moradia das pessoas será } \\
\text { melhor, elas terão melhores condições de vida. } \\
\text { Esperamos que o senhor tome a decisão certa. }\end{array}$ & $\begin{array}{l}\text { - Questões sociais e } \\
\text { políticas (valor à moradia } \\
\frac{\text { e ao coletivo) }}{\text { - Valor à vida }} \\
\text { - } \underline{\text { Raciocínio Moral }} \\
\underline{\text { Consequencialista }}\end{array}$ \\
\hline TR1 & $\begin{array}{l}\text { Caro prefeito, nós trabalhadores da construtora de } \\
\text { condomínios, poderíamos desmatar uma pequena } \\
\text { parte da floresta para construir o condomínio que } \\
\text { ocupe menos espaço da floresta, por um espaço } \\
\text { razoável. Se não construirmos o condomínio, não } \\
\text { teremos salários, isso afetaria as ações da empresa. } \\
\underline{\text { Tudo o que desmatarmos será reposto em outro }} \\
\underline{\text { ungar. Esperamos que compreenda. }}\end{array}$ & $\begin{array}{l}\text { - Questões sociais e } \\
\text { políticas (valor aos } \\
\text { recursos financeiros) } \\
\text { - } \underline{\text { Respeito ao meio }} \\
\underline{\text { ambiente }} \\
\text { - } \underline{\text { Raciocínio Moral }} \\
\underline{\text { Consequencialista }}\end{array}$ \\
\hline TR2 & $\begin{array}{l}\text { Senhor prefeito, como trabalhadores da obra nova, } \\
\text { dizemos que essa obra só trará coisas ruins para } \\
\text { nossa cidade. Os únicos pontos positivos são: teria } \\
\text { mais moradia, valorizaria a região e teriam mais } \\
\text { empregos. Já os pontos negativos são muitos: } \\
\text { acabariam com todo o verde, ou seja, desmatariam, }\end{array}$ & $\begin{array}{l}\text { - Questões sociais } \mathrm{e} \\
\text { políticas (valor ao } \\
\text { coletivo, à moradia e aos } \\
\underline{\text { recursos financeiros) }} \\
\text { - } \underline{\text { Respeito ao meio }} \\
\underline{\text { ambiente }}\end{array}$ \\
\hline
\end{tabular}




\begin{tabular}{|c|c|c|}
\hline & $\begin{array}{l}\text { gastaria mais água, por causa de eletricidade e } \\
\text { também como as árvores não estariam mais lá não } \\
\text { daria para transformar gás carbônico em ar } \\
\text { (oxigênio). Realmente para nós, trabalhadores, seria } \\
\text { bom por causa do salário, mas pensando na } \\
\text { população da cidade, não valeria a pena. } \\
\text { Aguardamos retorno. }\end{array}$ & $\begin{array}{l}\text { - } \quad \underline{\text { Raciocínio }} \text { Moral } \\
\text { Consequencialista }\end{array}$ \\
\hline TR3 & $\begin{array}{l}\text { Caro prefeito (...), temos o prazer de informar a } \\
\text { Vossa Senhoria que estamos de parcial acordo com } \\
\text { sua respeitável proposta. Nossa condição é que } \\
\text { possamos incluir dentro do condomínio (...) uma } \\
\text { área das árvores que replantaremos para compensar } \\
\underline{\text { o desmatamento. (...) Então, os moradores poderão }} \\
\underline{\text { interagir diretamente com a natureza. O projeto }} \\
\text { levará seis meses para ser completo. Gratos. }\end{array}$ & $\begin{array}{l}\text { - } \text { Respeito ao meio } \\
\text { ambiente } \\
\text { - Questões sociais e } \\
\text { políticas (valor ao } \\
\underline{\text { coletivo) }} \\
\text { - } \quad \text { Raciocínio Moral } \\
\text { Deontológico }\end{array}$ \\
\hline
\end{tabular}

Tabela 3 - Respostas dos alunos identificando os padrões morais e valores.

\subsubsection{Discussão sobre os padrões morais presentes nos elementos dos argumentos dos alunos}

Na tabela 3, classifico os padrões morais presentes nas respostas dos alunos. Nesse ponto de análise, percebo que treze textos produzidos pelos grupos (AN1, AN3, CM1, CM2, CC1, PE1, PE2, MA1, MA2, MA3, TR1, TR2 e TR3) utilizam o Raciocínio Moral Consequencialista, representado por escolhas que levam em consideração as consequências das ações. Esse tipo de raciocínio informal se dá por conta da natureza da questão sociocientífica, que pede aos estudantes que argumentem sobre a construção ou não do condomínio. Tal questão estimula, na maioria dos casos, o aparecimento desse tipo de posicionamento por parte dos alunos, dessa forma suas respostas ilustram a consequência que essas ações podem ocasionar como a resposta de um dos grupos da comunidade que retira o seu sustento da floresta: 
CM1: Caro prefeito, não gostamos muito dessa sua ideia. Tudo bem, haverá mais lugares de lazer, de trabalho para nós e também mais moradias, mas também vão causar mortes, não teremos mais sustentação, causará um desastre na floresta, estragará a moradia dos animais, acabará com os nossos recursos naturais e extinção de alguns animais. Mas, se o senhor vai construir esse tal de condomínio, deve deixar um espaço para os animais, pois esse é o habitat deles, também deve deixar recursos para eles e para nós. Prefeito, se você gostou de nossa ideia, então demore um bom tempo, para conseguirmos outro habitat para os animais e também outro lugar para que retirássemos os nossos sustentos. Há mais um pedido: se você construísse mais algumas florestas (já que só tem essa pequenina), aí sim você poderia fazer o condomínio, pois teríamos outros lugares melhores. Obrigado por sua consideração. Esperamos que goste de nossas ideias e as atenda.

O grupo CC3 é o único que não apresenta um argumento formalmente válido, dessa maneira utiliza a Moral Intuitiva para responder a questão proposta. Essa categoria explica que os participantes da atividade fazem conclusões sobre a problemática abordada sem utilizarem nenhum tipo de justificativa. Há apenas a escolha moral baseada na intuição do que é certo e errado sem embasamento algum.

CC3: "Caro prefeito, nós do comércio observamos e analisamos sua ideia de expandir a cidade e o condomínio. A sua ideia será apoiada por nós, mesmo sendo péssima ideia em relação ao meio ambiente e ao clima."

Essa resposta não explicita porque a ideia da construção do condomínio será apoiada pelo grupo e porque a mesma ideia é péssima para o meio ambiente e para o clima. Essa falta de decisão pode estar diretamente relacionada a pouca discussão que o grupo realizou, não conseguindo listar nem os pontos positivos, nem os pontos negativos desse dilema. Assim, não foi possível a construção de argumentação científica conforme proposto pelo modelo de Toulmin (2006).

Já o Raciocínio Moral Deontológico aparece em poucas respostas (CM3, CC2, PE3 e TR3), porque, na maioria dos casos, os alunos utilizaram conteúdos do próprio filme para 
embasar suas conclusões, ao invés de princípios morais. Para esse tipo de classificação, os alunos devem justificar suas conclusões a partir de princípios morais, como a resposta exemplificada a seguir:

CC2: "Caro prefeito, listamos pontos positivos e negativos da construção do condomínio. Os pontos negativos são a área desmatada, que fará falta para os animais, deixando eles sem abrigo e sem comida. E por outro lado, terá mais lazer para os humanos, gerando mais empregos. É uma decisão difícil para nós, por isso queremos que escolha a melhor opção. Caso faça o condomínio esperamos que pense na mata e nos animais. Aguardamos resposta."

A justificativa utilizada para embasar a conclusão do argumento ("que fará falta para os animais") é de natureza moral, não apresentando nenhum conceito científico por trás, por isso é caracterizado como Raciocínio Moral Deontológico.

Os grupos AN2 e CM3 apresentam em suas respostas a Moral Emotiva ao se colocarem no lugar da pessoa fictícia, que está vivenciando o dilema moral, preocupando-se com o bem-estar e empatia dos participantes. Neste caso, constroem argumentos, porém, não utilizam como garantias e apoios, os conceitos científicos presentes no filme. $\mathrm{O}$ exemplo abaixo ilustra esse tipo de resposta:

AN2: "Caro prefeito, nós animais da floresta estamos mandando uma carta para falar sobre os horríveis desmatamentos e poluições em nossa casa, floresta. Nós exigimos nosso espaço! Vamos escrever uma lista com tudo o que precisamos: comida, água, árvores. Com isso, nós comunicamos que podem matar apenas 1/5 de nossa floresta. Obrigado."

\subsubsection{Discussão sobre os valores empregados pelos alunos em suas respostas}

Na tabela 3, conforme explicado anteriormente, identifico os valores empregados nas respostas dos alunos ao responderem à questão sociocientífica proposta. A partir dessa 
análise, faço uma categorização e uma breve discussão sobre os valores presentes em suas respostas.

Os valores foram categorizados da seguinte maneira:

- Respeito ao meio ambiente: É o valor que aparece na maioria das respostas, quatorze grupos (AN1, AN2, AN3, CM1, CM2, CC1, CC3, PE1, PE3, MA1, MA2, TR1, TR2 e TR3) utilizam-no na construção de seus argumentos. A mensagem que pretendem transmitir é a de que não se devem destruir as florestas, porque os animais não terão mais onde morar, o ar não ficará limpo e a água pode acabar.

AN3: "Caro prefeito, nós, animais da floresta, não concordamos com o desmatamento de nossa casa, porque primeiro não vamos ter onde morar, segundo nós não sobreviveremos sem ter onde morar (...)."

- Valor à vida: Esse valor é expresso nas respostas de seis grupos (AN1, AN3, CM1, CM3, PE1, PE2 e MA3), os alunos defendem que não se devem destruir as florestas para não levar os animais à morte ou, até mesmo, extinção.

AN1: "Prefeito, nós em nome de todos os animais da floresta, achamos pontos negativos e positivos em construir o condomínio. Os pontos negativos são: vocês vão nos matar, deixando-nos sem água, lar e comida, a cadeia alimentar irá se prejudicar e nós entraremos em extinção porque o ciclo da cadeia alimentar irá mudar prejudicando nossas vidas e dos predadores, para você isso não é nada, mas para nós isso é muito importante, também podemos levar choques com fios elétricos ou sermos pegos por armadilhas. (...) Chegando a esse ponto nós achamos que será melhor não construir o condomínio, porque irá nos prejudicar e prejudicar vocês."

- Questões sociais e políticas: Os valores referentes às questões sociais e políticas apresentam diferentes parâmetros, que podem ser divididos em: 
- Valor ao coletivo: Apesar de apresentar diversos pontos a favor do condomínio, de acordo com o segmento que está representado, coloca-se como contra a construção ao alegar que será melhor para o coletivo. Nove grupos defendem essa opinião (CM1, CM3, PE1, PE2, PE3, MA1, MA3, TR2 e TR3).

TR2: "Senhor prefeito, como trabalhadores da obra nova, dizemos que essa obra só trará coisas ruins para nossa cidade. Os únicos pontos positivos são: teria mais moradia, valorizaria a região e teriam mais empregos. Já os pontos negativos são muitos: acabariam com todo o verde, ou seja, desmatariam, gastaria mais água, por causa de eletricidade e também como as árvores não estariam mais lá não daria para transformar gás carbônico em ar (oxigênio). Realmente para nós, trabalhadores, seria bom por causa do salário, mas pensando na população da cidade, não valeria a pena.(...)”

- Valor à cultura: Esse valor aparece nas respostas dos alunos defendendo que o condomínio tem como principal ponto positivo proporcionar lazer aos seres humanos e unir as pessoas. Esse valor aparece em seis respostas de alunos (CM1, CC1, CC2, PE1, MA1 e MA2).

PE1: "Seu Prefeito, há mais pontos positivos do que negativos (...). Os pontos positivos são: conforto, lazer para a comunidade, (...) tem mais comunicação entre pessoas. (...)”

- Valor à moradia: Os alunos apresentam esse valor em suas respostas ao defenderem a importância de se ter onde morar, não importa se é um animal da floresta ou um ser humano. Oito grupos apresentam esse juízo de valor (AN2, AN3, CM1, CC2, MA1, MA2, MA3 e TR2).

MA3: “Caro Senhor Prefeito, nós, ambientalistas da cidade, estamos protestando sobre o desmatamento da cidade para a construção de um condomínio, porque há vários pontos negativos: o ar será mais poluído, pois não terá mais árvores, os animais que moram na 
floresta, perderão suas casas, se não existirem plantas, não existirão herbívoros, não existirão carnívoros e se não existirão carnívoros e herbívoros, não existirá mais vida. Mas, também há vários pontos positivos: a moradia das pessoas será melhor, elas terão melhores condições de vida. Esperamos que o senhor tome a decisão certa..”

- Valor aos recursos financeiros: É importante a construção do condomínio para o desenvolvimento da cidade e para fornecer empregos aos trabalhadores da construtora. Esse juízo de valor é defendido por seis grupos de alunos (CC1, CM1, CM3, CC2 e TR2).

TR3: "Senhor prefeito, como trabalhadores da obra nova, dizemos que essa obra só trará coisas ruins para nossa cidade. Os únicos pontos positivos são: teria mais moradia, valorizaria a região e teriam mais empregos. Já os pontos negativos são muitos: acabariam com todo o verde, ou seja, desmatariam, gastaria mais água, por causa de eletricidade e também como as árvores não estariam mais lá não daria para transformar gás carbônico em ar (oxigênio). Realmente para nós, trabalhadores, seria bom por causa do salário, mas pensando na população da cidade, não valeria a pena. Aguardamos retorno."

\subsection{Discussão sobre os posicionamentos dos alunos em suas respostas à questão sociocientífica proposta}

A atividade proposta tinha como objetivo fazer com que os alunos defendessem um posicionamento sobre a construção ou não do condomínio em uma área de floresta. Os grupos de alunos deveriam defender o ponto de vista do segmento da sociedade que estavam representando, apresentando os aspectos positivos e negativos dessa decisão.

Os grupos AN1, AN3, CM3, PE1, MA1 e MA2 tomam posição, apresentando elementos contra a construção do condomínio. Já os grupos CC1 e CC3 apresentam elementos a favor à construção. Esses posicionamentos eram esperados na atividade, uma 
vez que os alunos responderam de acordo com o segmento da sociedade que estavam representando.

Porém, as respostas dos grupos CC2, PE2 e MA3 não definem nenhum posicionamento (nem contra e nem a favor à construção do condomínio). Dessa forma, esses grupos não conseguem definir a melhor decisão a ser tomada, deixando a decisão final para o prefeito da cidade.

Alguns grupos (AN2, CM1, CM2 e TR2) apresentam elementos contra e outros elementos a favor à construção do condomínio em suas respostas. Porém, constroem a ideia, de maneira indireta, de que eram contra a construção do condomínio, por apresentarem mais pontos negativos do que positivos em suas respostas, como a resposta exemplificada a seguir:

CM1: "Senhor prefeito, como trabalhadores da obra nova, dizemos que essa obra só trará coisas ruins para nossa cidade. Os únicos pontos positivos são: teria mais moradia, valorizaria a região e teriam mais empregos. Já os pontos negativos são muitos: acabariam com todo o verde, ou seja, desmatariam, gastaria mais água, por causa de eletricidade e também como as árvores não estariam mais lá não daria para transformar gás carbônico em ar (oxigênio). Realmente para nós, trabalhadores, seria bom por causa do salário, mas pensando na população da cidade, não valeria a pena. Aguardamos retorno."

Os grupos PE3, TR1 e TR3 mostram-se preocupados com a questão ambiental, propondo que a floresta seja plantada em outro lugar como solução para o desmatamento, porém defendem o ponto de vista do segmento da sociedade que estão representando, sendo a favor à construção do condomínio, como na resposta a seguir:

PE3: "Prezado prefeito, sua construção, por um lado, pode nos ajudar melhorando nossa condição de vida, mas por outro lado ela iria prejudicar muito o meio ambiente causando muitos danos a ele e nós nos preocupamos com isso. Queremos morar em um lugar melhor, mas para isso é preciso que você não prejudique o meio ambiente para não ficarmos tão preocupados. Obrigado!” 


\section{Considerações finais}

O movimento CTSA (Ciência-Tecnologia-Sociedade-Ambiente) aborda as questões sociocientíficas com o intuito de estimular os estudantes a tornarem-se capazes de criticar situações acerca do ensino de ciências, as quais estão cada vez mais presentes em seu cotidiano através de dilemas ambientais (Kolsto, 2001, Bell \& Lederman, 2003; Osborne et al., 2004; Sadler et al., 2007; Sadler et al., 2004; Wu \& Tsai, 2007; Kortland, 1996). Neste trabalho foi analisada uma questão com esse enfoque CTSA, sendo caracterizada como sócio-ambiental.

A questão sociocientífica ou sócio-ambiental sobre o desmatamento em uma área de floresta, proposta aos alunos do $5^{\circ}$ ano do ensino fundamental, propiciou a construção de respostas com uma diversidade de conceitos científicos, padrões morais e valores. A análise das respostas dos estudantes a partir do padrão de argumentação de Toulmin (2006) foi fundamental para as considerações deste trabalho.

Analiso que a questão proposta teve grande influência no desenvolvimento dos discursos argumentativos dos alunos, os quais foram, na maioria dos grupos, caracterizados como argumentos formalmente válidos.

A temática foi selecionada por se tratar de uma questão bastante divulgada e discutida nos dias de hoje. Iniciar a discussão partindo da apresentação de um filme infantojuvenil mostrou-se uma excelente ferramenta para que os alunos produzissem seus textos. Os alunos utilizaram tanto conceitos científicos presentes no filme como também padrões morais e valores em suas respostas. Dessa forma percebo como as questões sociocientíficas são capazes de nortear a construção de argumentação e de instigar o uso de padrões morais e valores.

O estudo dos padrões morais a partir das questões sociocientíficas é extremamente relevante, já que permite o acesso aos tipos de raciocínio informal que os sujeitos utilizam ao abordar as questões morais e éticas. Devemos dar maior ênfase aos estudos sobre o raciocínio informal, uma vez que eles são os que realmente acontecem na sala de aula e na vida em sociedade.

O estudo dos valores nos processos de discussão sociocientífica também deve ser estimulado, já que eles aparecem em muitas respostas dos alunos. Os valores são essenciais nas 
discussões de temas polêmicos, são eles que regulam e permeiam a vida em sociedade, sendo papel dos professores e da escola trabalhar essas questões em sala de aula por causa da complexidade desse tipo de questão, há muitas variáveis que podem ser analisadas.

Além disso, os alunos utilizam os principais conceitos científicos apresentados no filme na construção de suas respostas colocando esses conceitos principalmente no papel da garantia (W). A escolha das garantias (W) para justificar suas respostas mostra a importância que os alunos dão às mensagens presentes no filme, uma vez que a garantia tem a função de estabelecer a relação entre o dado e a conclusão.

Considerando que a construção de argumentação é um dos objetivos do ensino de ciências e que as questões sociocientíficas estimulam essa construção, devemos utilizá-las quando a intenção for a produção argumentativa.

Alguns grupos de alunos não tomaram posição sobre a questão proposta, apenas apresentaram pontos positivos e negativos sobre o desmatamento. Analiso essa insegurança na tomada de decisão devido à maneira como a atividade foi conduzida. A questão propôs que os alunos escrevessem os pontos positivos e os negativos da construção do condomínio, o que os forçou a pensarem sobre os dois pontos de vista e produzirem suas respostas, dessa maneira não puderam tomar uma posição definitiva pela própria natureza da questão.

O filme, por sua vez, discute diferentes problemáticas, porém não toma nenhuma posição, apenas apresenta as questões com o objetivo de entreter o público. Essa característica do material trabalhado também foi um fator determinante na construção das respostas dos alunos. O filme se torna neutro por intenção, para não entrar em choque com nenhum posicionamento principalmente dos patrocinadores do material.

Após essa análise, percebo a grande relevância que as mensagens do filme refletem nas respostas dos alunos, mostrando que esse tipo de material exerce grande influência na construção de significados pelos sujeitos que o assistem. Dessa forma, os filmes podem ser uma excelente ferramenta no ensino de ciências por utilizarem uma linguagem descontraída e apresentarem uma relação entre as diferentes linguagens (imagens, sons e movimentos).

Como esse recurso é uma importante ferramenta para o ensino de ciências, o seu uso deve ser refletido pelos professores, pensando nos objetivos a serem atingidos, para que as discussões que pretendem atingir possam ser alcançadas. Os professores devem mostrar aos alunos os diferentes pontos de vista do filme, tornando-os capazes de refletirem sobre esse 
tipo de material, que é amplamente divulgado pelos meios de comunicação e que faz parte da realidade deles, principalmente fora da escola.

É necessário que a utilização de questões sociocientíficas para trabalhar os conceitos científicos, a moralidade e a ética tenham maior destaque nas pesquisas em ensino de ciências e que sejam trabalhadas em situações de sala de aula para formamos cidadãos críticos e conscientes das questões presentes em nossa sociedade atual.

\section{Referências}

\subsection{Filmografia}

OS SEM FLORESTA (2006). Tim Johnson \& Karey Kirkpatrick (dir.) DreamWorks SKG, animação. (83 min), son., col. (Título original: Over the hedge). EUA.

\subsection{Referências bibliográficas}

ACEVEdo, J. A., VÁZQUeZ, A., MARTín, M., Oliva, J. M., ACEVEdo, P., PAIXÃO, M. F. \& MANASSERO, M. A. (2005). Naturaleza de la ciência y educación científica para la participación ciudadana. Una revisión crítica. Revista Eureka sobre Enseñanza y divulgación de las ciencias, vol. 2, n. 2, pp. 121-140. Associación de professores amigos de la ciencia: EUREKA. Cádiz, España.

ADAM, J. M. (1992). Les textes: types et prototypes. París: Nathan

AMARAL, M. B. (1997). (Tele) natureza e a construção do natural: um olhar sobre imagens de natureza na publicidade. In: OLIVEIRA, D. L. de (org.) Ciências nas Salas de Aula (Cadernos de Educação Básica 2), p. 83-96, Porto Alegre: Mediação.

ARROIO, A. \& GIORDAN, M. (2006). O vídeo educativo: aspectos da organização do ensino. Química nova na escola, vol. 24, pp. 8 - 11. São Paulo.

BAKHTIN, Mikhail (V. N. Volochínov) (1988). Marxismo e Filosofia da Linguagem. 4.ed. Trad: Michel Lahud e Yara Frateschi Vieira. São Paulo: Hucitec, 1988, 203 p.

BELL, R. L., \& LEDERMAN, N. G. (2003). Understandings of the nature of science and decision making on science and technology based issues. Science Education, vol. 87, n. 3, p. 352-377. 
BINGLE, W.H. \& GASKELL. P. J. (1994) Scientific literacy for decision making and the social construction of scientific knowledge. Science Education, vol. 78, n. 2, p. 185 - 201.

BONOTTO, D. M. B. (2008). Contribuições para o trabalho com valores em educação ambiental. Ciência \& Educação, v. 14, n. 2, p. 295-306.

BRAKE, M. (2003). Science fiction in the Classroom. Physics Education, v. 38, n.1. p. 3134.

BROWN, B.. REVELES, J. \& KELLY, G. (2005) Scientific Literacy and Discursive Identity: A Theoretical Framework for Understanding Science Education. Science Education, 89, 779-802.

CANDELA, A. (1997) El discurso argumentativo de la Ciência em la aula. Encontro sobre Teoria e Pesquisa em Ensino de Ciências, Belo Horizonte.

CAPECCHI, M. C. V. M, CARVALHO, A. M. P. \& SILVA, D. (2002). Argumentação dos alunos e discurso do professor em uma aula de Física. Ensaio - Pesquisa em Educação em Ciências, vol. 2, n. 2, p. 189-208.

CARVALHO, A. M. P. (2007). Habilidades de professores para promover a enculturação científica. LaPEF (Laboratório de Pesquisa em Ensino de Física), no prelo.

CAZELLI, S. \& FRANCO, C. (2001). Alfabetismo científico: novos desafios no contexto da globalização. Ensaio - Pesquisa em Educação em Ciências, v.3, n. 1, junho.

CROSS, R. T. \& PIERCE, R. F. (2002). Teaching controversal science for social responsibility: The case of food production. In: ROTH, W. M. \& DÉSAUTELS, J.: Science education as/for sociopolitical action, p. 99 - 123. New York: Peter Lang.

DARK, M. (2005). Using Science Fiction Movies in Introductory Physics. Phys. Teach. n. 43. p. 463- 465.

DIJK, T.A. VAN (1978). La ciencia del texto. Barcelona: Paidós.

DOOLEY, R. A. \& LEVINSOHN, S. H. (2003). Análise do Discurso: Conceitos básicos em lingüística. Petrópolis: Editora Vozes.

DRIVER, R., NEWTON, P., \& OSBORNE, J. (2000). Establishing the norms of scientific argumentation in classrooms. Science Education, vol. 84, n. 3, p. 287-312.

DUARTE, R. (2002). Cinema \& educação: refletindo sobre cinema e educação. Belo Horizonte: Autêntica. 
DUBCEK, L. W. et al. (1998). Sci-Fi in the Classroom: Making a "Deep Impact" on Young People's Interest in Science. Mercury, p. 24-28.

FARRE M., BOSCH F., ROSET P. N. \& BANOS J. E. (2004). Putting clinical pharmacology in context: the use of popular movies. Journal Clinical of Pharmacology. $\mathrm{v}$. 44. n. 1. p. 30-36.

FISCHER, R. M. B. (2001). Foucault e a análise do discurso em educação. Cadernos de Pesquisa, n. 114, p. 197-223, novembro.

FLEMING, R. W. (1986a). Adolescent reasoning in socio-scientific issues, part I: Social cognition. Journal of research in science teaching, vol. 23, n. 8, p. $677-687$.

FLEMING, R. W. (1986b). Adolescent reasoning in socio-scientific issues, part II: Nonsocial cognition. Journal of research in science teaching, vol. 23, n. 8, p. $689-698$.

FOUCAULT, M. (1986). A Arqueologia do saber. Rio de Janeiro: Forense.

FOUREZ, G. (2004). Crise no ensino de ciências. Investigações no ensino de ciências.

FREIRE, P. Pedagogia do oprimido. 18. ed. Rio de Janeiro: Paz \& Terra, 1988.

FREUDENRICH, C. (2000). Sci-Fi Science: Using Science Fiction to set Context for Learning Science. The Science Teacher v. 67, n. 8., p. 42-45.

GOMES-MALUF, M. C. \& SOUZA, A. R. (2008). A ficção científica e o ensino de ciências: o imaginário como formador do real e do racional. Ciência \& Educação, v. 14, n. 2, p. 271-282.

GREGOLIN, M. R. (2003). A mídia e a especularização da cultura. In: GREGOLIN, M. R. (org.), Discurso e mídia: a cultura do espetáculo. São Carlos: Claraluz editora.

JENKINS, E. W. (1999). Comprensión pública de la ciencia y enseñanza de la ciencia para la acción. Revista de Estudios del Currículum, vol. 2, n. 2, p. 7 - 22.

JEWITT, C., GUNTHER, K., OGBORN, J. \& CHARALAMPOS, T. (2001). Exploring learning through visual, actional and linguistic communication: the multimodal environment of a science classroom. Educational Review, vol. 53, n. 1, p. 5 - 18 .

JIMÉNEZ ALEIXANDRE, M. P. (2005). A argumentação sobre questões sócio-científicas: processos de construção e justificação do conhecimento na aula.

JIMÉNEZ ALEIXANDRE, M.P. \& BUSTAMANTE, J.D. (2003). Discurso de aula y argumentación en la clase de ciencias: Cuestiones teóricas y metodológicas. Enseñanza de las ciencias, vol. 21, n. 3, p. $359-370$. 
JIMÉNEZ ALEIXANDRE, M.P., RODRÍGUEZ, A.B. \& DUSCHL, R. (2000). "Doing the lesson"' or “doing science"': Argument in high school genetics. Science Education, vol. 84, n. 6, p. 757-792.

JIMÉNEZ-ALEIXANDRE, M. P., REIGOSA CASTRO, C. \& ÁLVAREZ PÉREZ, V. (1998). Argumentación em el Laboratório de Física. Trabalho apresentado no VII Encontro de Pesquisa em Ensino de Física, 26 a 30 de outubro, Florianópolis.

JOHNSON, R.H., \& BLAIR, J.A. (1991). Contexts of informal reasoning: commentary. In VOSS, J.F., PERKINS, D.N., \& SEGAL, J.W. (org.), Informal reasoning and education, pp. 131 - 150. Hillsdale, NJ: Erlbaum.

KOCH, I. G. V. (1987). Argumentação e Linguagem. 2a . ed, São Paulo: Cortez Editora.

KOLSTØ, S.D. (2001). Scientific literacy for citizenship: Tools for dealing with the science dimension of controversial socioscientific issues. Science Education, vol. 85, n. 3, p. 291310.

KOMINSKI, L. \& GIORDAN, M. (2002). Visões de ciências e sobre cientista entre estudantes do Ensino Médio. Química Nova na Escola, São Paulo, n. 15, p. 11-8, p. 11.

KONDER, L. (1992). O futuro da filosofia da práxis. 2a ed. Rio de Janeiro: Paz \& Terra.

KORTLAND, K. (1996). An STS case study about students' decision making on the waste issue. Science Education, vol. 80, p. 673-689.

KUHN, D. (1993). Science as argument: Implications for teaching and learning scientific thinking. Science Education, vol. 77, n. 3, p. 319-337.

KUHN, D. (1991). The skills of argument. Cambridge, England: Cambridge University Press.

LEE, M-H., WU, Y-T. \& TSAI, C-C. (2009). Research Trends in Science Education from 2003 to 2007: A content analysis of publications in selected journals. International Journal of Science Education, vol. 31, n. 15, p. 1999 - 2020.

LEMKE, J.L. (2006). Investigar para el futuro de la educación científica: Nuevas formas de aprender, nuevas formas de vir. Enseñanza de las ciencias, vol. 24, n. 1, p. 5 - 12.

LIBÂNEO, J. C. (1990). Fundamentos teóricos e práticos do trabalho docente: estudo introdutório sobre pedagogia e didática. Tese de doutoramento. São Paulo: Pontifícia Universidade Católica de São Paulo. 
LOUREIRO, C. F. B. (2005). Complexidade e dialética: contribuições à práxis política e emancipatória em Educação Ambiental. Educação e Sociedade, vol. 26, n. 93, p. 1473 1494, Set. / Dez., Campinas.

MACHADO, C. A. (2008). Filmes de ficção científica como mediadores de conceitos relativos ao meio ambiente, Ciência \& educação (Bauru), v. 14, n. 2, p. 283-294.

MAIA, J. M. C., CASTILHO, S., MAIA, M. C. \& NETO, F., L. (2005). Psicopatologia no cinema brasileiro: um estudo introdutório, Rev. Psiq. Clín. n. 32. v. 6. p. 319-323.

MEANS, M.L. \& VOSS, J.F. (1996). Who reasons well? Two studies of informal reasoning among children of different grade, ability, and knowledge levels. Cognition and Instruction, vol. 14, p. 139-178.

MESQUITA, N. A. S. \& SOARES, M. H. F. B. (2008). Visões de ciência em desenhos animados: uma alternativa para o debate sobre a construção do conhecimento científico em sala de aula. Ciência \& Educação, v. 14, n. 3, p. 417-29.

MUNEIRO, L. \& OLIVEIRA, M. E. (2007). Dano moral ou caso de política? O aquecimento global e o discurso verde. Um exame crítico do filme-documentário "Uma verdade inconveniente”. História, imagem e narrativas, n. 5, ano 3, p. 1-18.

NAPOLITANO, M. (2003). Como usar o cinema na sala de aula. São Paulo: Contexto.

ORGANISATION FOR ECONOMIC CO-OPERATION AND DEVELOPMENT (2000). Measuring students knowledge and skills: the Pisa 2000 assessment of reading, mathematical and scientific literacy. Paris: OECD.

OSAKABE, H. (1979). Argumentação e discurso político. São Paulo: Kairós Livraria e Editora.

OSBORNE, J., ERDURAN, S. \& SIMON, S. (2004). Enhancing the Quality of Argumentation in School Science. Journal of Research in Science Teaching vol. 41, n. 10, p. 994-1020.

PALACIOS, S. L. (2007). EL cine y la literatura de ciencia ficción como herramientas didácticas en la enseñanza de la física: una experiencia en el aula. Rev. Eureka. Enseñ. Divul. Cien., n. 4, v. 1, p. 106-122.

PAPPAS G., SEITARIDIS S., AKRITIDIS N. \& TSIANOS E. (2003). Infectious diseases in cinema: virus hunters and killer microbes. Clin. Infect. Dis. v. 37, n. 7. p. 939-942.

PATRONIS, T., POTARI, D., \& SPILIOTOPOULOU, V. (1999). Students' argumentation in decisionmaking on a socio-scientific issue: Implications for teaching. International Journal of Science Education, vol. 21, 745-754. 
PEDRETTI, E. (1999). Decision making and STS education: Exploring scientific knowledge and social responsibility in schools and science centers through an issues-based approach. School Science and Mathematics, vol. 99, p. $174-181$.

PERKINS, D.N., FARADY, M. \& BUSHEY, B. (1991). Everyday reasoning and the roots of intelligence. In VOSS, J.F., PERKINS, D.N., SEGAL, J.W. (org.), Informal reasoning and education, p. 83 -105. Hillsdale: Erlbaum.

PERKINS, D.N., ALLEN, R., \& HANFER, J. (1983). Dificulties in every day reasoning. In Maxwell, W. (org.), Thinking the expanding frontier, p. 83 - 105. Philadelphia: Franklin Instate Press.

PIASSI, L. P. \& PIETROCOLA, M. (2009). Ficção científica e ensino de ciências: para além do método de 'encontrar erros em filmes. Educação e Pesquisa, São Paulo, v.35, n.3, p. 525-540.

PIASSI, L. P. \& PIETROCOLA, M. (2006). Possibilidades dos filmes de ficção científica como recurso didático em aulas de física: a construção de um instrumento de análise. $\mathrm{X}$ Encontro de Pesquisa em Ensino de Física. Londrina, 2006. Disponível em: http://www.sbf1.sbfisica.org.br/eventos/epef/x/sys/resumos/T0047-1.pdf.

REZENDE, L. A. \& STRUCHINER, M. (2009). Uma Proposta Pedagógica para Produção e Utilização de Materiais Audiovisuais no Ensino de Ciências: análise de um vídeo sobre Entomologia. ALEXANDRIA Revista de Educação em Ciência e Tecnologia, v.2, n.1, p.45-66.

ROSE, C. (2007). Biology in the movies: Using the double-edged sword of popular culture to enhance public understanding of science. Evolutionary Biology, v. 34, n. 1-2, p. 49-54.

ROSE, C. (2003). How to teach Biology using the movie science of cloning people, ressurrecting the dead, and combining flies and humans. Public Understanding of science, v. 12 , n. 3, p. 289-296.

SADLER, T. D., BARAB, S. A. \& SCOTT, B. (2007). What Do Students Gain by Engaging in Socioscientific Inquiry? Research in Science Education, vol. 37, p. 371-391.

SADLER, T. D. (2004). Informal Reasoning Regarding Socioscientific Issues: A Critical Review of Research. Journal of Research in Science Teaching, vol. 41, n. 5, p. 513-536.

SADLER, T. D., CHAMBERS, W. F. \& ZEIDLER, D. L. (2004). Student Conceptualizations of the Nature of Science in Response to a Socioscientific Issue. International Journal of Science Education, vol. 26, n. 4, p. 387 - 409. 
SADLER, T. D. \& ZEIDLER, D. L. (2004). The Morality of Socioscientific Issues: Construal and Resolution of Genetic Engineering Dilemmas. Science Education, vol. 88, p. 4-27.

SAITO, C. H. (2002). Política Nacional de Educação Ambiental e Construção da Cidadania: Desafios Contemporâneos. In: RUSCHEINSKY (org.). Educação Ambiental: abordagens múltiplas, p. 49 - 60. Porto Alegre. Artmed.

SANTOS, W. L. P. \& MORTIMER, E. F. (2009). Abordagem de aspectos sociocientíficos em aulas de ciências: possibilidades e limitações. Investigações em Ensino de Ciências, v.14, n. 2, p. 191-218.

SARDÀ JORGE, A. \& SANMARTÍ PUIG, N. (2000). Enseñar a argumentar científicamente: un reto de las clases de ciencias. Enseñanza de las ciencias, vol. 18, n. 3, p. 405-422.

SCARPA, D.L. (2009). Cultura escolar e cultura científica: aproximações, distanciamentos e hibridações por meio da análise de argumentos no ensino de biologia e na Biologia. Tese de doutorado. Faculdade de Educação. Universidade de São Paulo.

SHAW, D. et al. (2000). Science and the Popular Media. Science Activities. v. 37, n. 2, p. $22-31$.

TOMAZI, A. L., PEREIRA, A. J., SCHULER, C. M., PISKE, K. \& TOMIO, D. (2009). $O$ que é e quem faz ciência? Imagens sobre a atividade científica divulgadas em filmes de animação infantil. Ensaio - Pesq. Educ. Ciênc. v.11, n.2. p. 1-19.

TOULMIN, S. E. (2006). Os usos do argumento. $2^{\mathrm{a}}$. ed. São Paulo: Martins Fontes.

TOULMIN, S.E. (1993). Les usages de l'argumentation. París: PUF. (1a. ed. The uses of Argument, 1958).

TSAI, C.-C., \& WEN, L.M.C. (2005). Research and trends in science education from 1998 to 2002: A content analysis of publication in selected journals. International Journal of Science Education, vol. 27, p. 3-14.

VYGOTSKY, L. S. (1934). Pensamento e linguagem. Trad: Jeferson Luiz Camargo. São Paulo: Martins Fontes, 1995. 135p. Tradução de: Thought and language, 1934, Cambridge, MA: MIT Press.

WU, Y. T. \& TSAI, C. C. (2007). High School Students' Informal Reasoning on a Socio scientific Issue: Qualitative and Quantitative Analyses. International Journal of Science Education, vol. 29, n. 9, p. 1163-1187. 
YORE, L. D., BISANZ, G. L. \& HAND, B.M. (2003). Examining the literacy component of science literacy: 25 years of language arts and science research. International Journal of science education, vol. 25 , n. 6 , p. $689-725$.

ZEIDLER, D. L. (1984). Moral issues and social policy in science education: Closing the literacy gap. Science education, vol. 68, n. 4, p. $411-419$.

ZEIDLER, D. L., WALKER, K. A., ACKETT, W. A. \& SIMMONS, M. L. (2002). Tangled Up in Views: Beliefs in the Nature of Science and Responses to Socioscientific Dilemmas. Science Education, vol. 86, p. 343-367.

ZEIDLER, D. L. \& SCHAFER, L. E. (1984). Identifying meditating factors of moral reasoning in science education. Journal of Research in Science Teaching, vol. 21, n. 1, p. 1 -15 .

ZOHAR, A. \& NEMET, F. (2002). Fostering students' knowledge and argumentation skills through dilemmas in human genetics. Journal of Research in Science Teaching, vol. 39, p. $35-62$. 
6. Anexos 


\section{ATIVIDADE: CARTA À PREFEITURA DE SANTO INÁCIO}

Vocês acabaram de assistir a um filme, que aborda uma questão ambiental muito comentada nos dias de hoje.

Imaginem que, na cidadezinha de Santo Inácio, a prefeitura está preste a decidir se permite ou não a construção de um condomínio com luz elétrica, saneamento básico e lazer. Mas, para isso, deverá desmatar uma área de floresta. Então, o prefeito, Seu Inácio, pede aos interessados que escrevam uma carta ressaltando todos os pontos positivos e negativos dessa construção, explicando cada um deles. Dessa maneira, conhecendo todos os pontos de vista, Seu Inácio poderá tomar a melhor decisão.

Vocês são pessoas que vivem na cidade sem as mínimas condições necessárias, o que vocês escreveriam para o prefeito? (Dica: antes de escreverem a carta, listem os pontos positivos e negativos dessa construção, pensem no máximo de possibilidades.)
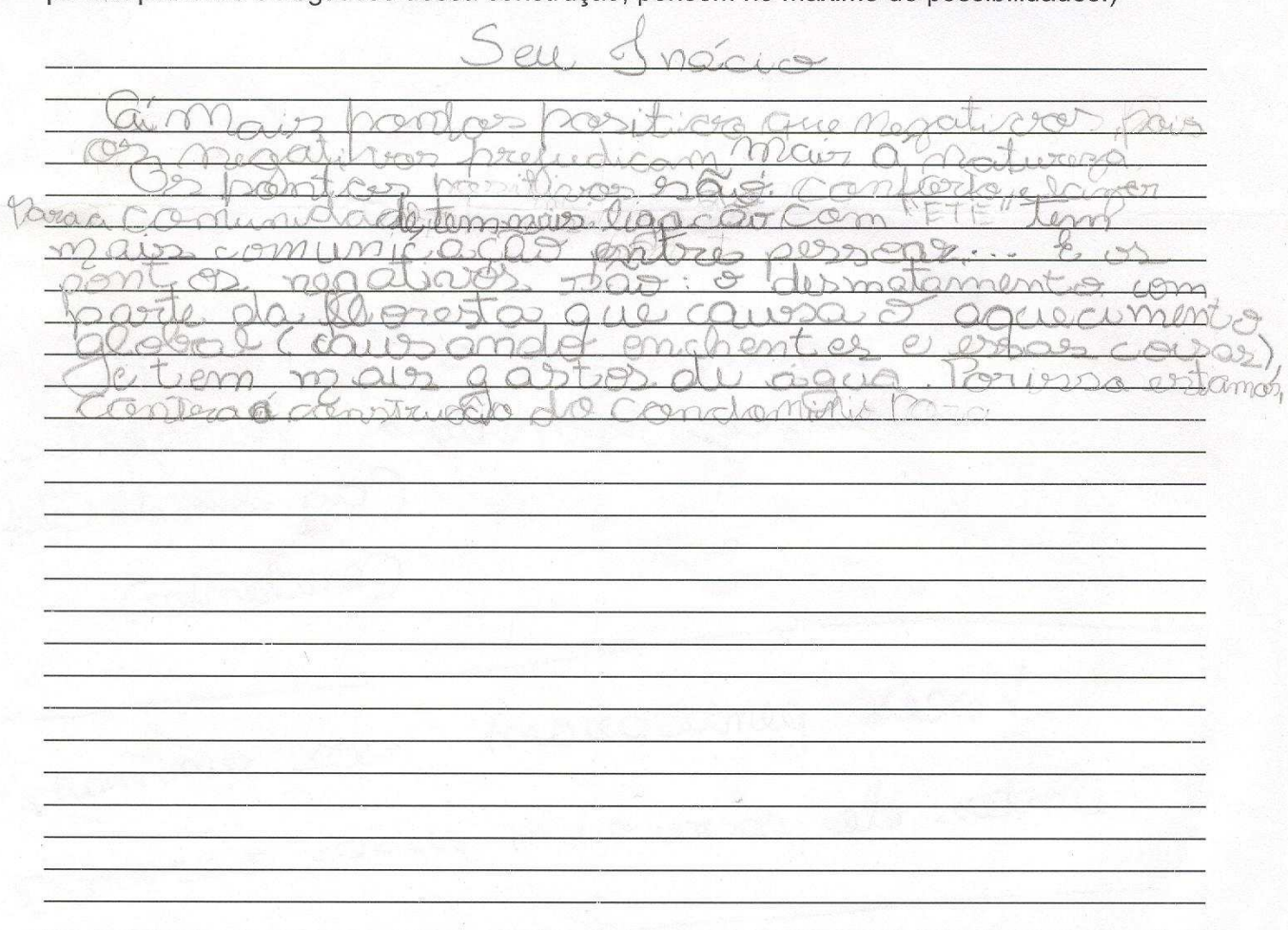


\section{ATIVIDADE: CARTA À PREFEITURA DE SANTO INÁCIO}

Vocês acabaram de assistir a um filme, que aborda uma questão ambiental muito comentada nos dias de hoje.

Imaginem que, na cidadezinha de Santo Inácio, a prefeitura está preste a decidir se permite ou não a construção de um condomínio com luz elétrica, saneamento básico e lazer Mas, para isso, deverá desmatar uma área de floresta. Então, o prefeito, Seu Inácio, pede aos interessados que escrevam uma carta ressaltando todos os pontos positivos e negativos dessa construção, explicando cada um deles. Dessa maneira, conhecendo todos os pontos de vista, Seu Inácio poderá tomar a melhor decisão.

Vocês são os animais que vivem nessa floresta, supondo que saibam escrever, o que vocês escreveriam para o prefeito? (Dica: antes de escreverem a carta, listem os pontos positivos e negativos dessa construção, pensem no máximo de possibilidades.)

Prapeato Inacúo

hoú am nome dé todos as anumas da plarcista, arhamos pontos negateros e pestures em contruit os condorninio.

Ds pentos negatwos Dare

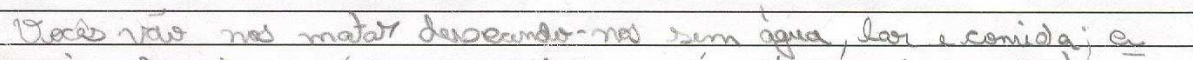

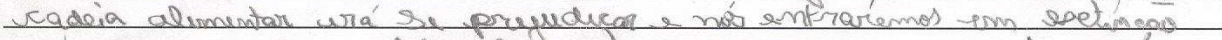

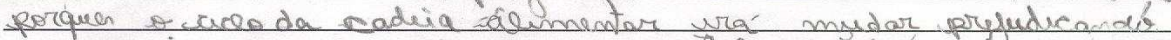

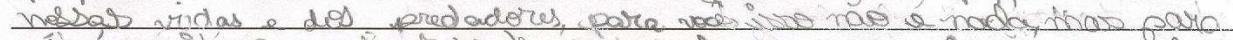

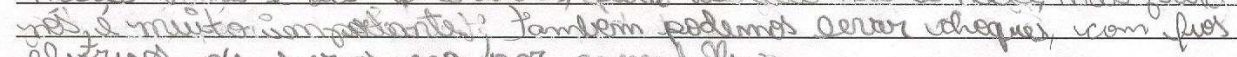

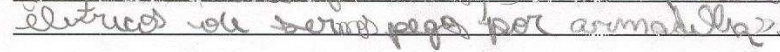

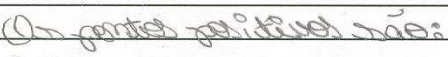

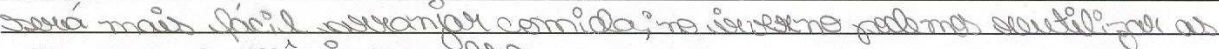
sigr pas que verèr iegam gera.

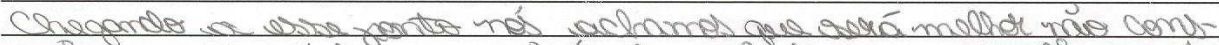

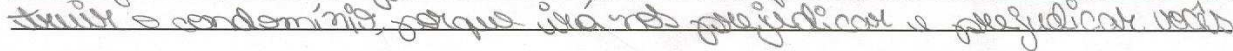

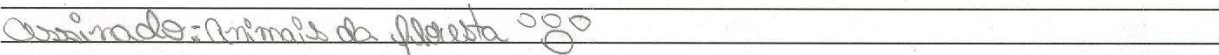

(1)

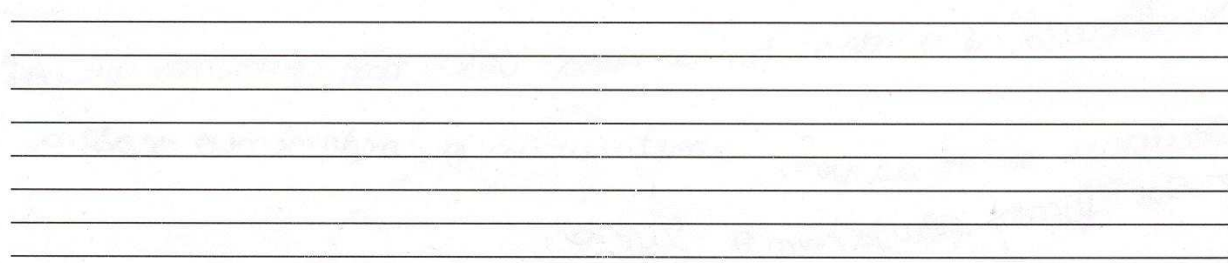




\section{ATIVIDADE: CARTA À PREFEITURA DE SANTO INÁCIO}

Vocês acabaram de assistir a um filme, que aborda uma questão ambiental muito comentada nos dias de hoje.

Imaginem que, na cidadezinha de Santo Inácio, a prefeitura está preste a decidir se permite ou não a construção de um condomínio com luz elétrica, saneamento básico e lazer. Mas, para isso, deverá desmatar uma área de floresta. Então, o prefeito, Seu Inácio, pede aos interessados que escrevam uma carta ressaltando todos os pontos positivos e negativos dessa construção, explicando cada um deles. Dessa maneira, conhecendo todos os pontos de vista, Seu Inácio poderá tomar a melhor decisão.

Vocês são trabalhadores da construtora de condomínios, o que vocês escreveriam para o prefeito? (Dica: antes de escreverem a carta, listem os pontos positivos e negativos dessa construção, pensem no máximo de possibilidades.)

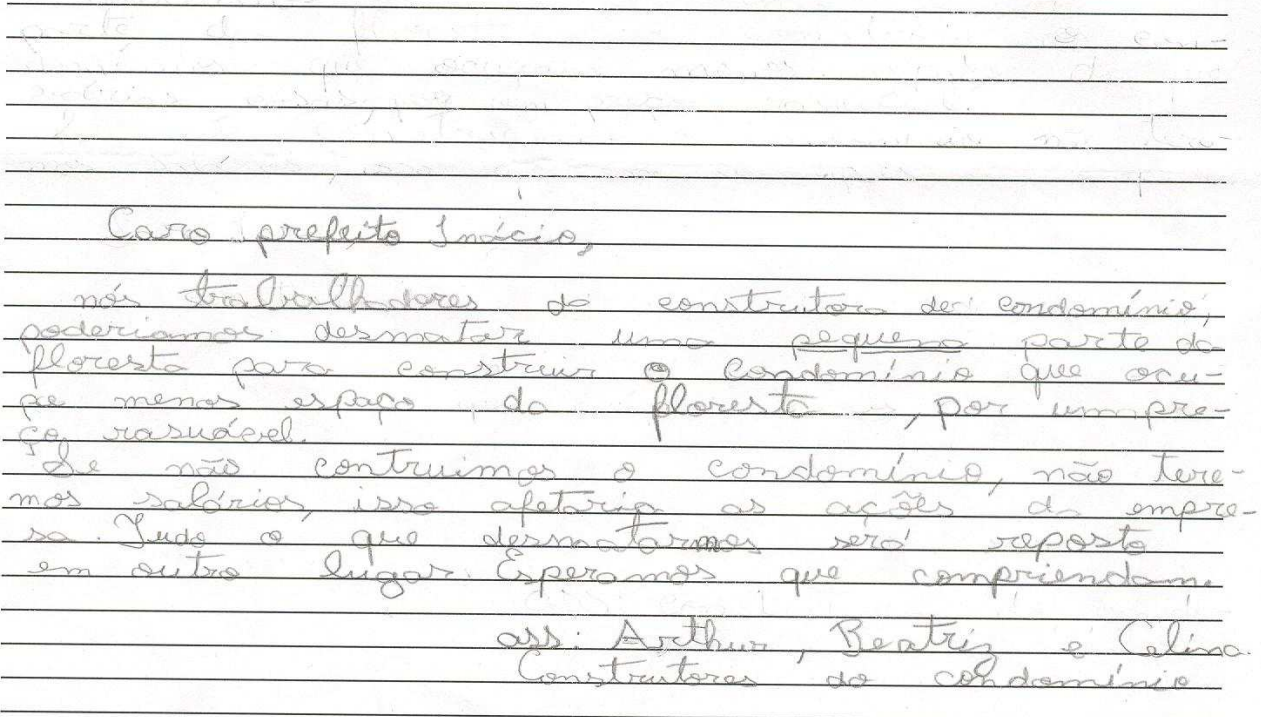




\section{ATIVIDADE: CARTA À PREFEITURA DE SANTO INÁCIO}

Vocês acabaram de assistir a um filme, que aborda uma questão ambiental muito comentada nos dias de hoje.

Imaginem que, na cidadezinha de Santo Inácio, a prefeitura está preste a decidir se permite ou não a construção de um condomínio com luz elétrica, saneamento básico e lazer. Mas, para isso, deverá desmatar uma área de floresta. Então, o prefeito, Seu Inácio, pede aos interessados que escrevam uma carta ressaltando todos os pontos positivos e negativos dessa construção, explicando cada um deles. Dessa maneira, conhecendo todos os pontos de vista, Seu Inácio poderá tomar a melhor decisão.

Vocês fazem parte do movimento ambientalista da cidade, o que vocês escreveriam para o prefeito? (Dica: antes de escreverem a carta, listem os pontos positivos e negativos dessa construção, pensem no máximo de possibilidades.)

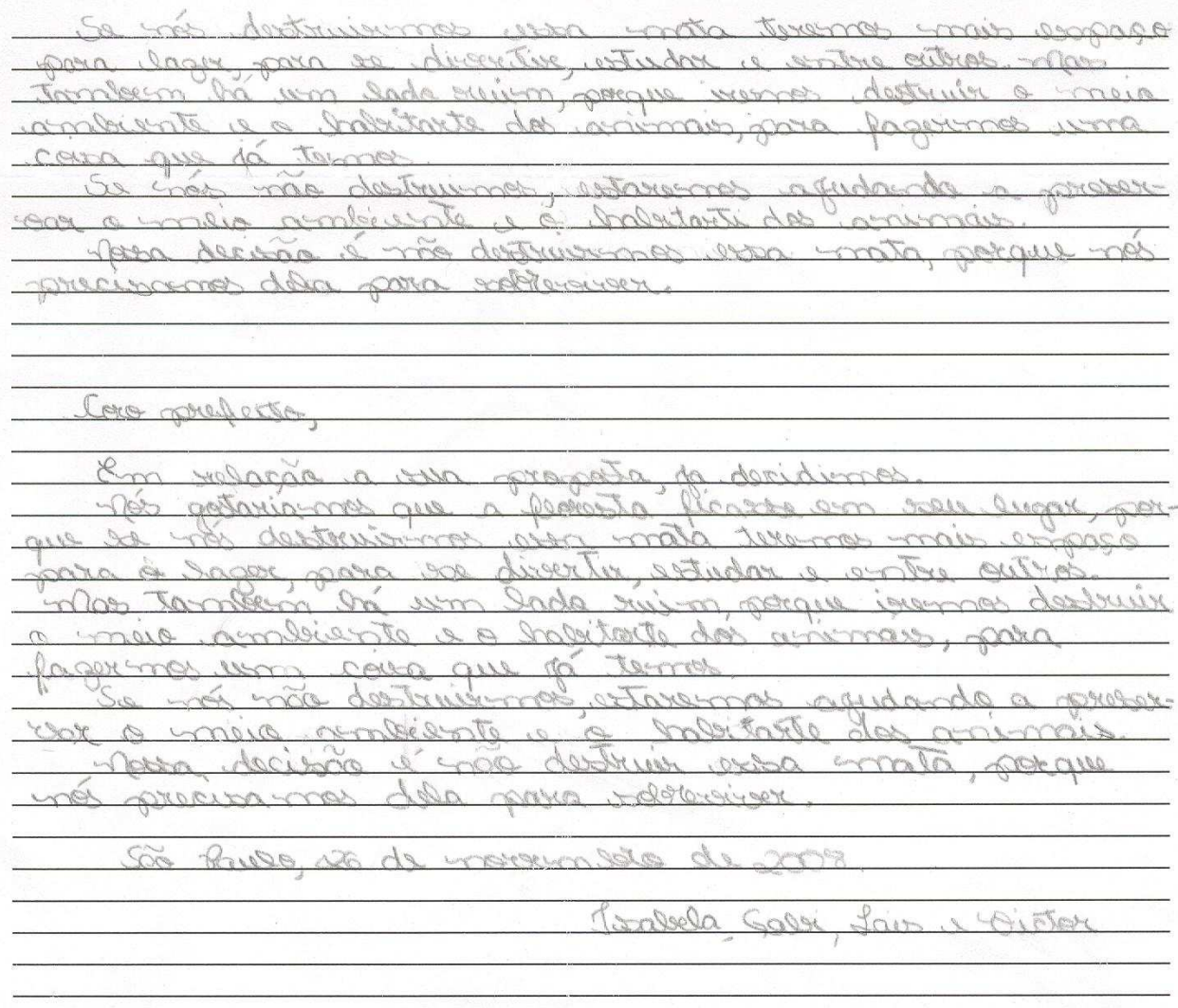




\section{ATIVIDADE: CARTA À PREFEITURA DE SANTO INÁCIO}

Vocês acabaram de assistir a um filme, que aborda uma questão ambiental muito comentada nos dias de hoje.

Imaginem que, na cidadezinha de Santo Inácio, a prefeitura está preste a decidir se permite ou não a construção de um condomínio com luz elétrica, saneamento básico e lazer. Mas, para isso, deverá desmatar uma área de floresta. Então, o prefeito, Seu Inácio, pede aos interessados que escrevam uma carta ressaltando todos os pontos positivos e negativos dessa construção, explicando cada um deles. Dessa maneira, conhecendo todos os pontos de vista, Seu Inácio poderá tomar a melhor decisão.

Vocês fazem parte de uma comunidade que retira seu sustento dessa floresta, o que vocês escreveriam para o prefeito? (Dica: antes de escreverem a carta, listem os pontos positivos e negativos dessa construção, pensem no máximo de possibilidades.)

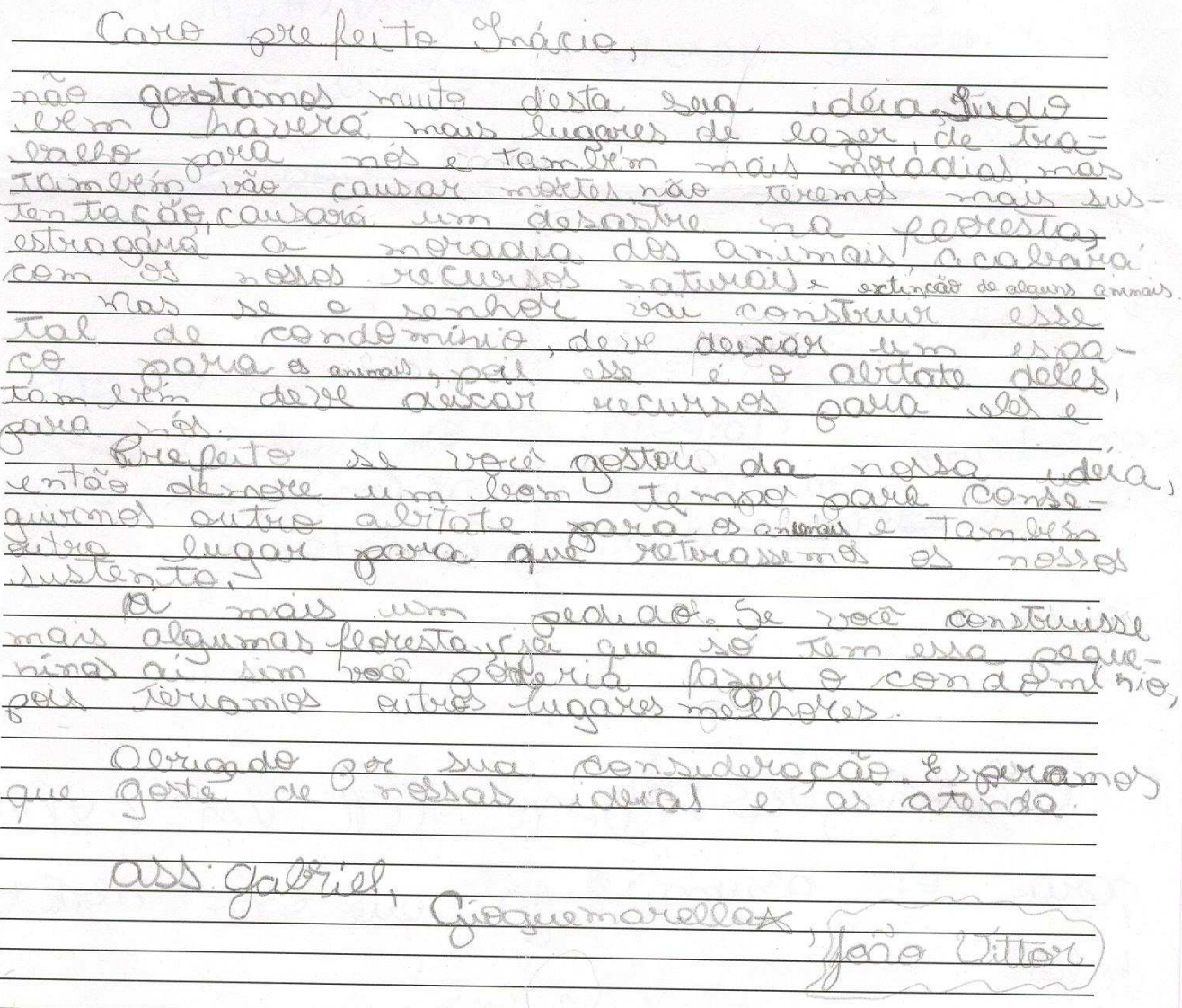




\section{ATIVIDADE: CARTA À PREFEITURA DE SANTO INÁCIO}

Vocês acabaram de assistir a um filme, que aborda uma questão ambiental muito comentada nos dias de hoje.

Imaginem que, na cidadezinha de Santo Inácio, a prefeitura está preste a decidir se permite ou não a construção de um condomínio com luz elétrica, saneamento básico e lazer. Mas, para isso, deverá desmatar uma área de floresta. Então, o prefeito, Seu Inácio, pede aos interessados que escrevam uma carta ressaltando todos os pontos positivos e negativos dessa construção, explicando cada um deles. Dessa maneira, conhecendo todos os pontos de vista, Seu Inácio poderá tomar a melhor decisão.

Vocês fazem parte do comércio da cidade, o que vocês escreveriam para o prefeito? (Dica: antes de escreverem a carta, listem os pontos positivos e negativos dessa construção, pensem no máximo de possibilidades.)

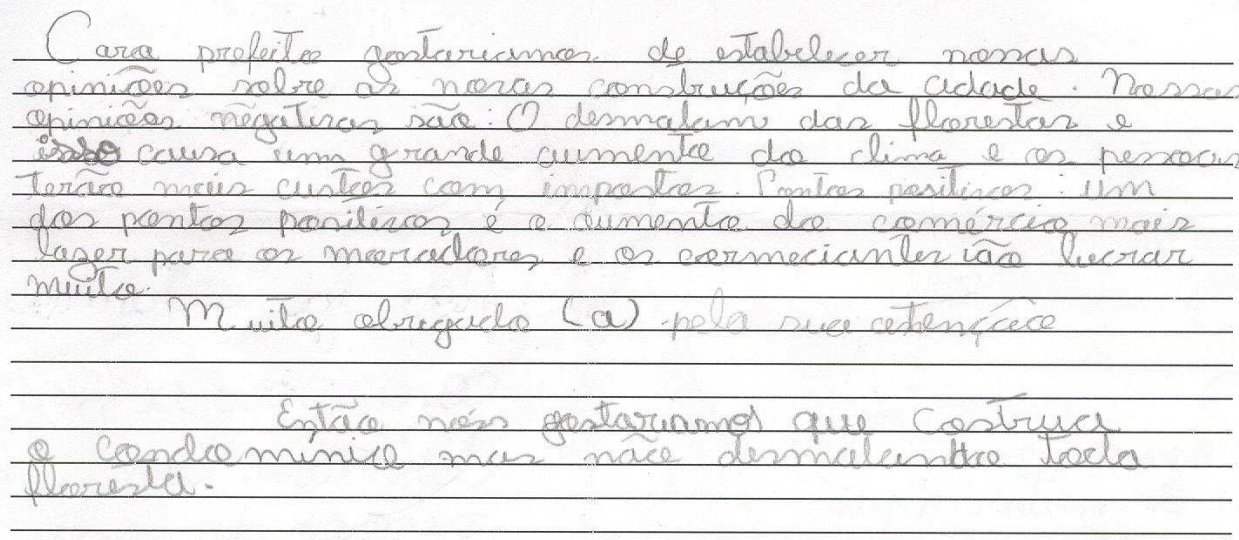
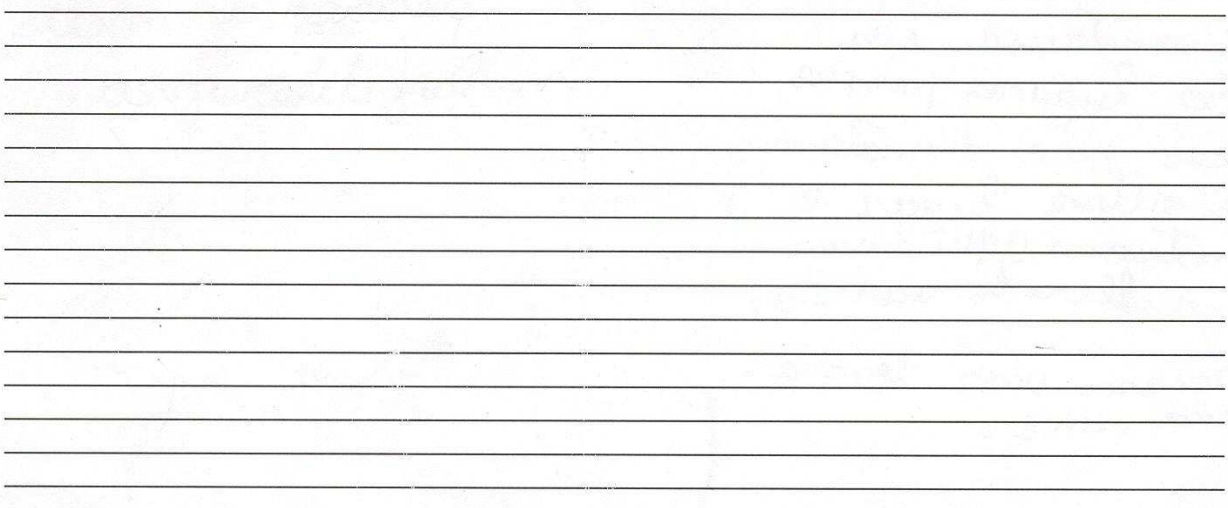

Ansinado. Caros comproiantes. 


\section{ATIVIDADE: CARTA À PREFEITURA DE SANTO INÁCIO}

Vocês acabaram de assistir a um filme, que aborda uma questão ambiental muito comentada nos dias de hoje.

Imaginem que, na cidadezinha de Santo Inácio, a prefeitura está preste a decidir se permite ou não a construção de um condomínio com luz elétrica, saneamento básico e lazer. Mas, para isso, deverá desmatar uma área de floresta. Então, o prefeito, Seu Inácio, pede aos interessados que escrevam uma carta ressaltando todos os pontos positivos e negativos dessa construção, explicando cada um deles. Dessa maneira, conhecendo todos os pontos de vista, Seu Inácio poderá tomar a melhor decisão.

Vocês fazem parte do movimento ambientalista da cidade, o que vocês escreveriam para o prefeito? (Dica: antes de escreverem a carta, listem os pontos positivos e negativos dessa construção, pensem no máximo de possibilidades.)
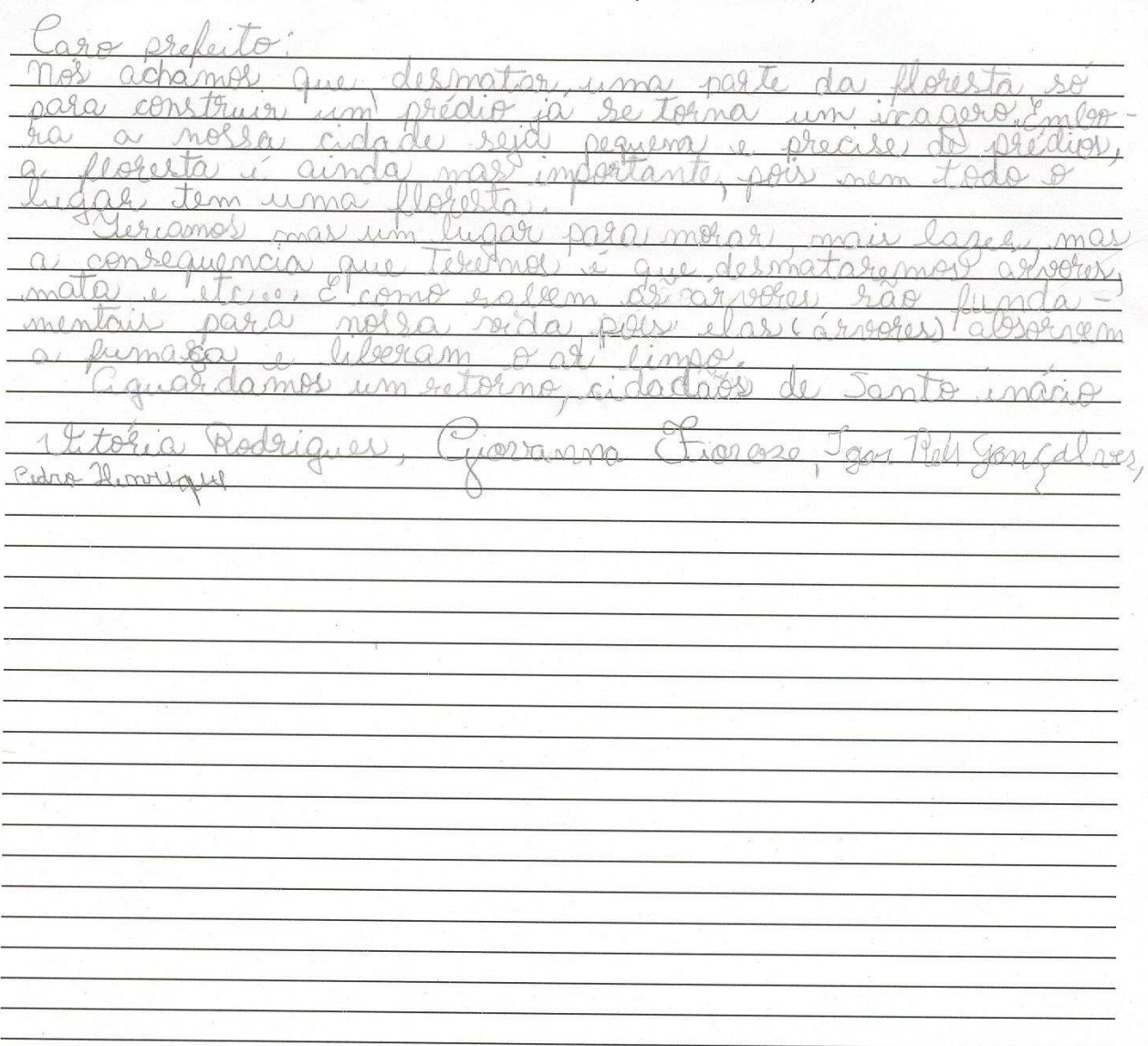


\section{ATIVIDADE: CARTA À PREFEITURA DE SANTO INÁCIO}

Vocês acabaram de assistir a um filme, que aborda uma questão ambiental muito comentada nos dias de hoje.

Imaginem que, na cidadezinha de Santo Inácio, a prefeitura está preste a decidir se permite ou não a construção de um condomínio com luz elétrica, saneamento básico e lazer. Mas, para isso, deverá desmatar uma área de floresta. Então, o prefeito, Seu Inácio, pede aos interessados que escrevam uma carta ressaltando todos os pontos positivos e negativos dessa construção, explicando cada um deles. Dessa maneira, conhecendo todos os pontos de vista, Seu Inácio poderá tomar a melhor decisão.

Vocês são pessoas que vivem na cidade sem as mínimas condições necessárias, o que vocês escreveriam para o prefeito? (Dica: antes de escreverem a carta, listem os pontos positivos e negativos dessa construção, pensem no máximo de possibilidades.)
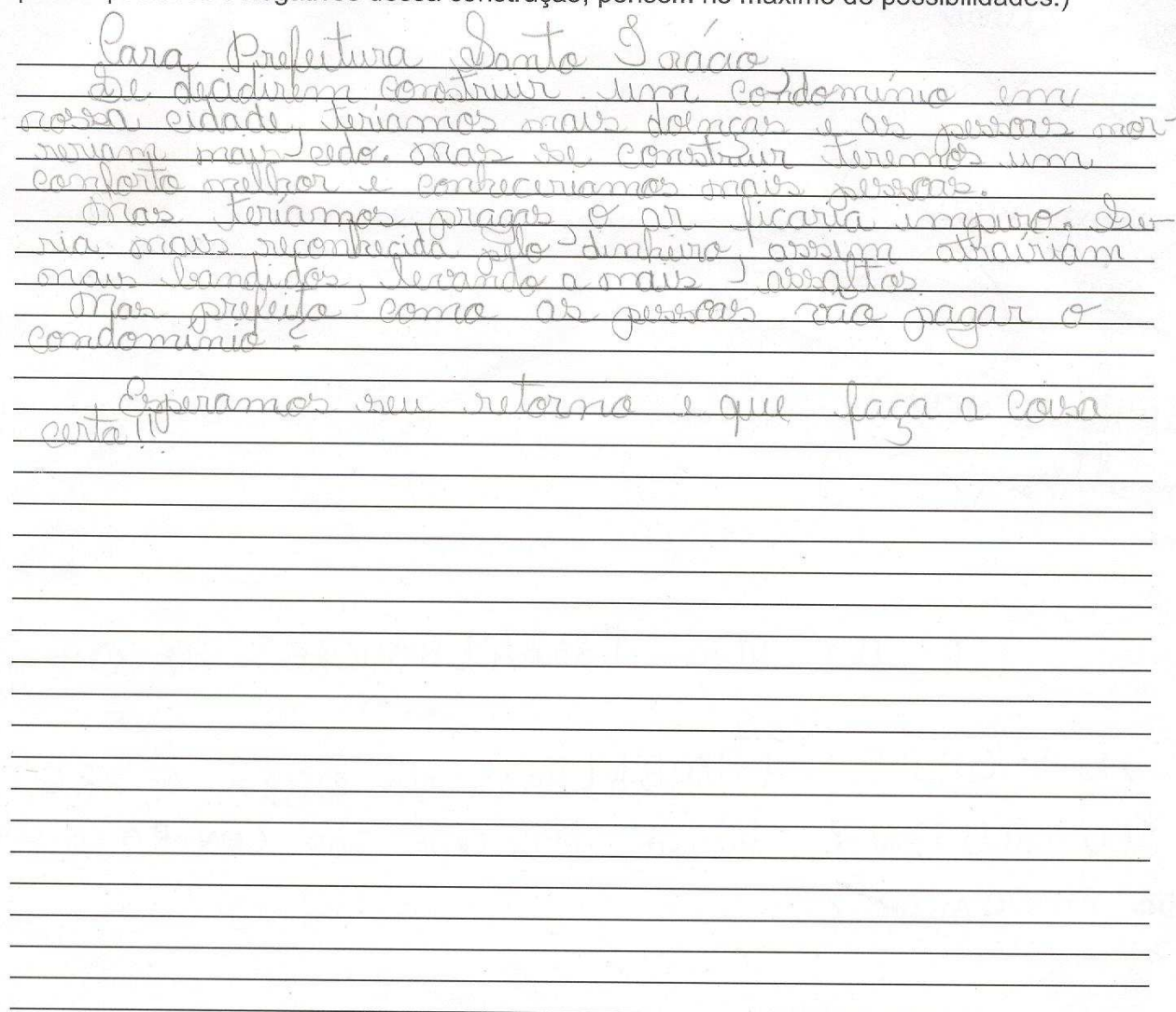


\section{ATIVIDADE: CARTA À PREFEITURA DE SANTO INÁCIO}

Vocês acabaram de assistir a um filme, que aborda uma questão ambiental muito comentada nos dias de hoje.

Imaginem que, na cidadezinha de Santo Inácio, a prefeitura está preste a decidir se permite ou não a construção de um condomínio com luz elétrica, saneamento básico e lazer. Mas, para isso, deverá desmatar uma área de floresta. Então, o prefeito, Seu Inácio, pede aos interessados que escrevam uma carta ressaltando todos os pontos positivos e negativos dessa construção, explicando cada um deles. Dessa maneira, conhecendo todos os pontos de vista, Seu Inácio poderá tomar a melhor decisão.

Vocês são os animais que vivem nessa floresta, supondo que saibam escrever, o que vocês escreveriam para o prefeito? (Dica: antes de escreverem a carta, listem os pontos positivos e negativos dessa construção, pensem no máximo de possibilidades.)
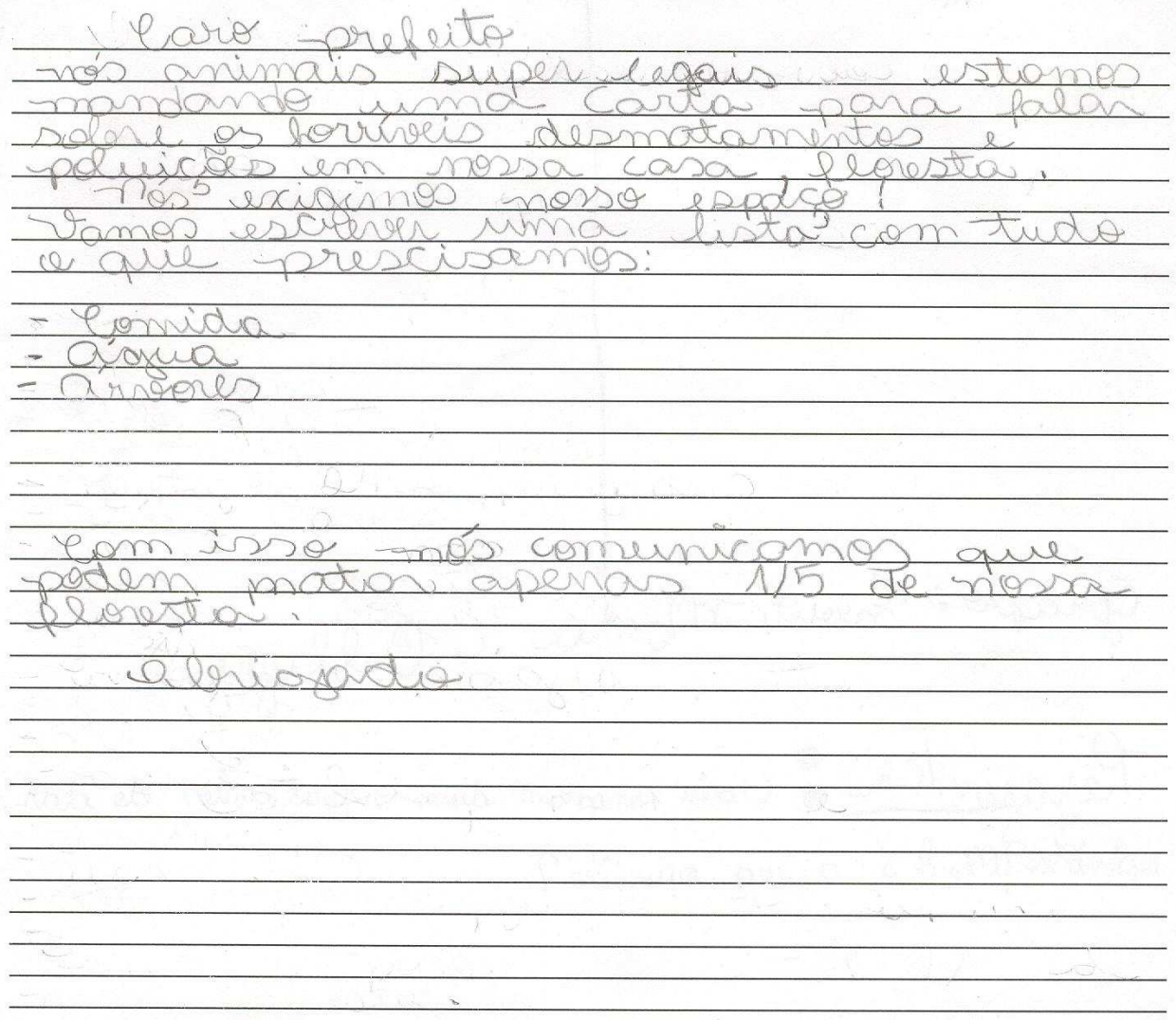


\section{ATIVIDADE: CARTA À PREFEITURA DE SANTO INÁCIO}

Vocês acabaram de assistir a um filme, que aborda uma questão ambiental muito comentada nos dias de hoje.

Imaginem que, na cidadezinha de Santo Inácio, a prefeitura está preste a decidir se permite ou não a construção de um condomínio com luz elétrica, saneamento básico e lazer. Mas, para isso, deverá desmatar uma área de floresta. Então, o prefeito, Seu Inácio, pede aos interessados que escrevam uma carta ressaltando todos os pontos positivos e negativos dessa construção, explicando cada um deles. Dessa maneira, conhecendo todos os pontos de vista, Seu Inácio poderá tomar a melhor decisão.

Vocês são trabalhadores da construtora de condomínios, o que vocês escreveriam para o prefeito? (Dica: antes de escreverem a carta, listem os pontos positivos e negativos dessa construção, pensem no máximo de possibilidades.)

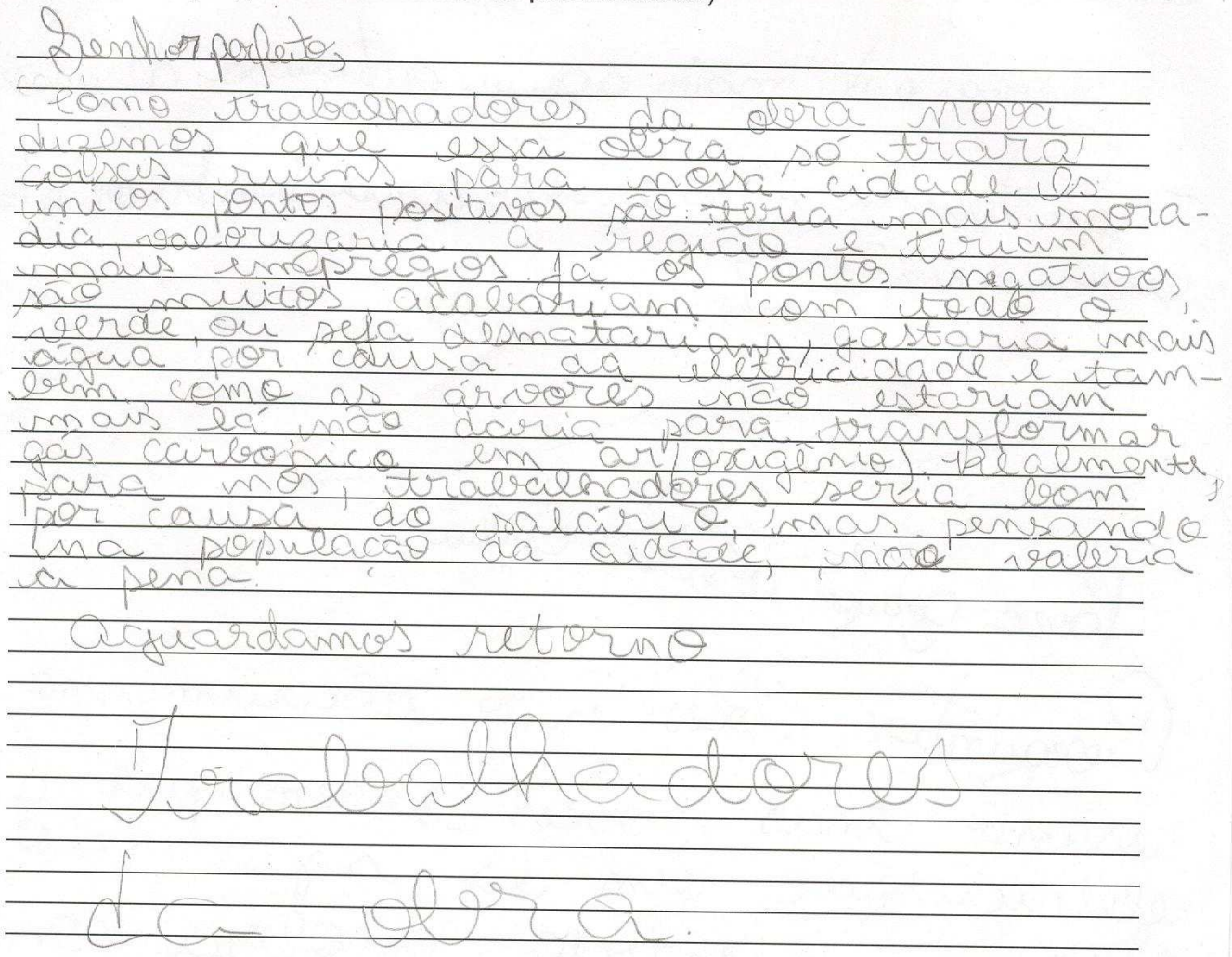




\section{ATIVIDADE: CARTA À PREFEITURA DE SANTO INÁCIO}

Vocês acabaram de assistir a um filme, que aborda uma questão ambiental muito comentada nos dias de hoje.

Imaginem que, na cidadezinha de Santo Inácio, a prefeitura está preste a decidir se permite ou não a construção de um condomínio com luz elétrica, saneamento básico e lazer. Mas, para isso, deverá desmatar uma área de floresta. Então, o prefeito, Seu Inácio, pede aos interessados que escrevam uma carta ressaltando todos os pontos positivos e negativos dessa construção, explicando cada um deles. Dessa maneira, conhecendo todos os pontos de vista, Seu Inácio poderá tomar a melhor decisão.

Vocês fazem parte de uma comunidade que retira seu sustento dessa floresta, o que vocês escreveriam para o prefeito? (Dica: antes de escreverem a carta, listem os pontos positivos e negativos dessa construção, pensem no máximo de possibilidades.)

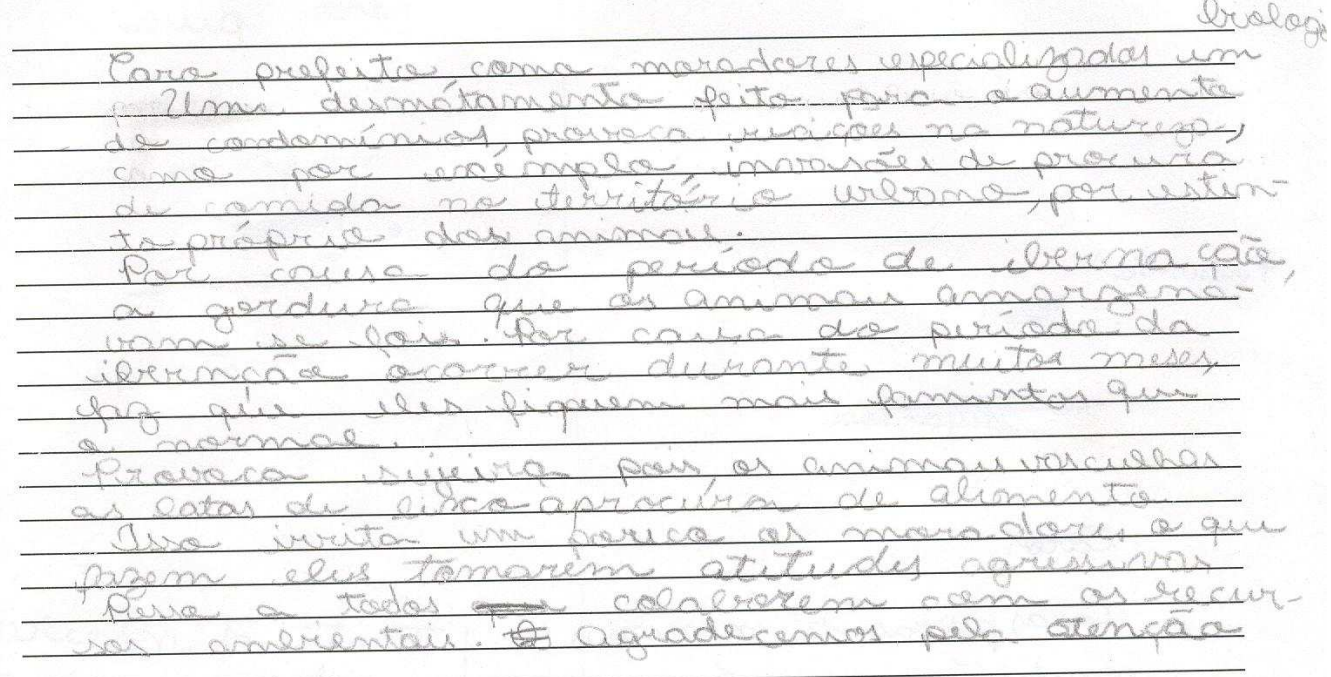




\section{ATIVIDADE: CARTA À PREFEITURA DE SANTO INÁCIO}

Vocês acabaram de assistir a um filme, que aborda uma questão ambiental muito comentada nos dias de hoje.

Imaginem que, na cidadezinha de Santo Inácio, a prefeitura está preste a decidir se permite ou não a construção de um condomínio com luz elétrica, saneamento básico e lazer. Mas, para isso, deverá desmatar uma área de floresta. Então, o prefeito, Seu Inácio, pede aos interessados que escrevam uma carta ressaltando todos os pontos positivos e negativos dessa construção, explicando cada um deles. Dessa maneira, conhecendo todos os pontos de vista, Seu Inácio poderá tomar a melhor decisão.

Vocês são trabalhadores da construtora de condomínios, o que vocês escreveriam para o prefeito? (Dica: antes de escreverem a carta, listem os pontos positivos e negativos dessa construção, pensem no máximo de possibilidades.)

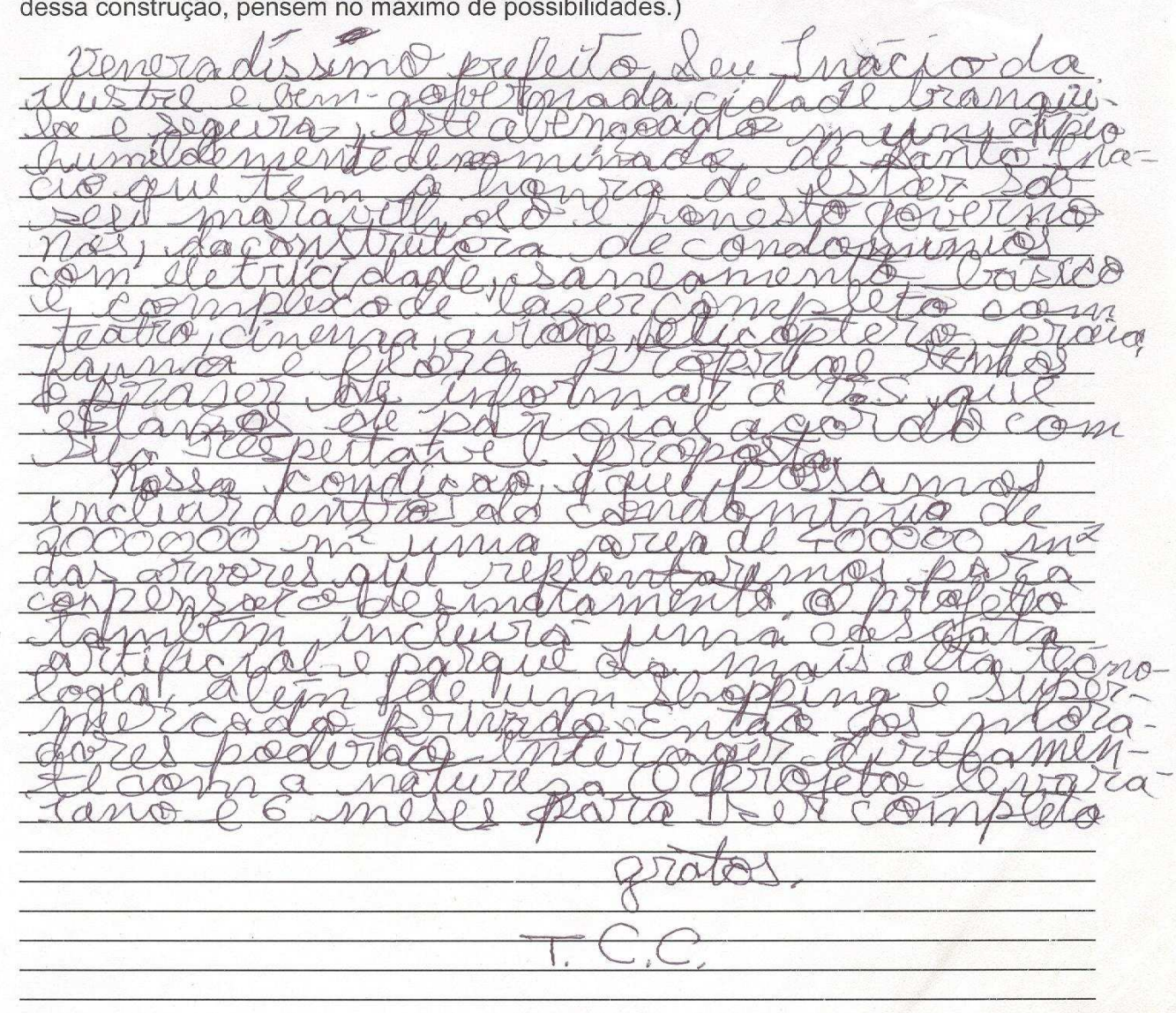




\section{ATIVIDADE: CARTA À PREFEITURA DE SANTO INÁCIO}

Vocês acabaram de assistir a um filme, que aborda uma questão ambiental muito comentada nos dias de hoje.

Imaginem que, na cidadezinha de Santo Inácio, a prefeitura está preste a decidir se permite ou não a construção de um condomínio com luz elétrica, saneamento básico e lazer. Mas, para isso, deverá desmatar uma área de floresta. Então, o prefeito, Seu Inácio, pede aos interessados que escrevam uma carta ressaltando todos os pontos positivos e negativos dessa construção, explicando cada um deles. Dessa maneira, conhecendo todos os pontos de vista, Seu Inácio poderá tomar a melhor decisão.

Vocês fazem parte do comércio da cidade, o que vocês escreveriam para o prefeito? (Dica: antes de escreverem a carta, listem os pontos positivos e negativos dessa construção, pensem no máximo de possibilidades.)

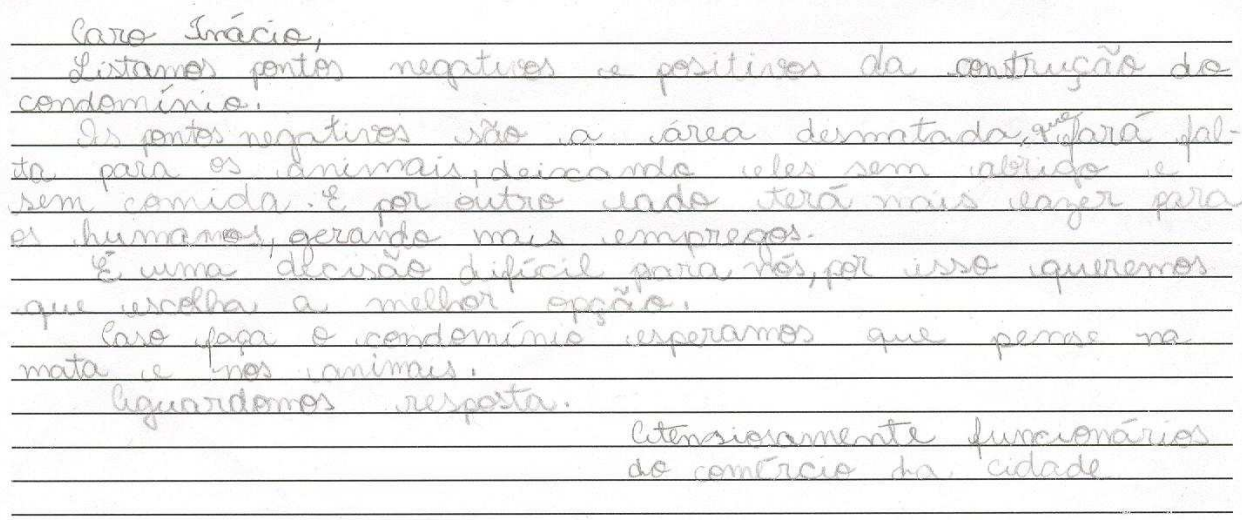




\section{ATIVIDADE: CARTA À PREFEITURA DE SANTO INÁCIO}

Vocês acabaram de assistir a um filme, que aborda uma questão ambiental muito comentada nos dias de hoje.

Imaginem que, na cidadezinha de Santo Inácio, a prefeitura está preste a decidir se permite ou não a construção de um condomínio com luz elétrica, saneamento básico e lazer Mas, para isso, deverá desmatar uma área de floresta. Então, o prefeito, Seu Inácio, pede aos interessados que escrevam uma carta ressaltando todos os pontos positivos e negativos dessa construção, explicando cada um deles. Dessa maneira, conhecendo todos os pontos de vista, Seu Inácio poderá tomar a melhor decisão.

Vocês são pessoas que vivem na cídade sem as mínimas condições necessárias, o que vocês escreveriam para o prefeito? (Dica: antes de escreverem a carta, listem os pontos positivos e negativos dessa construção, pensem no máximo de possibilidades.)

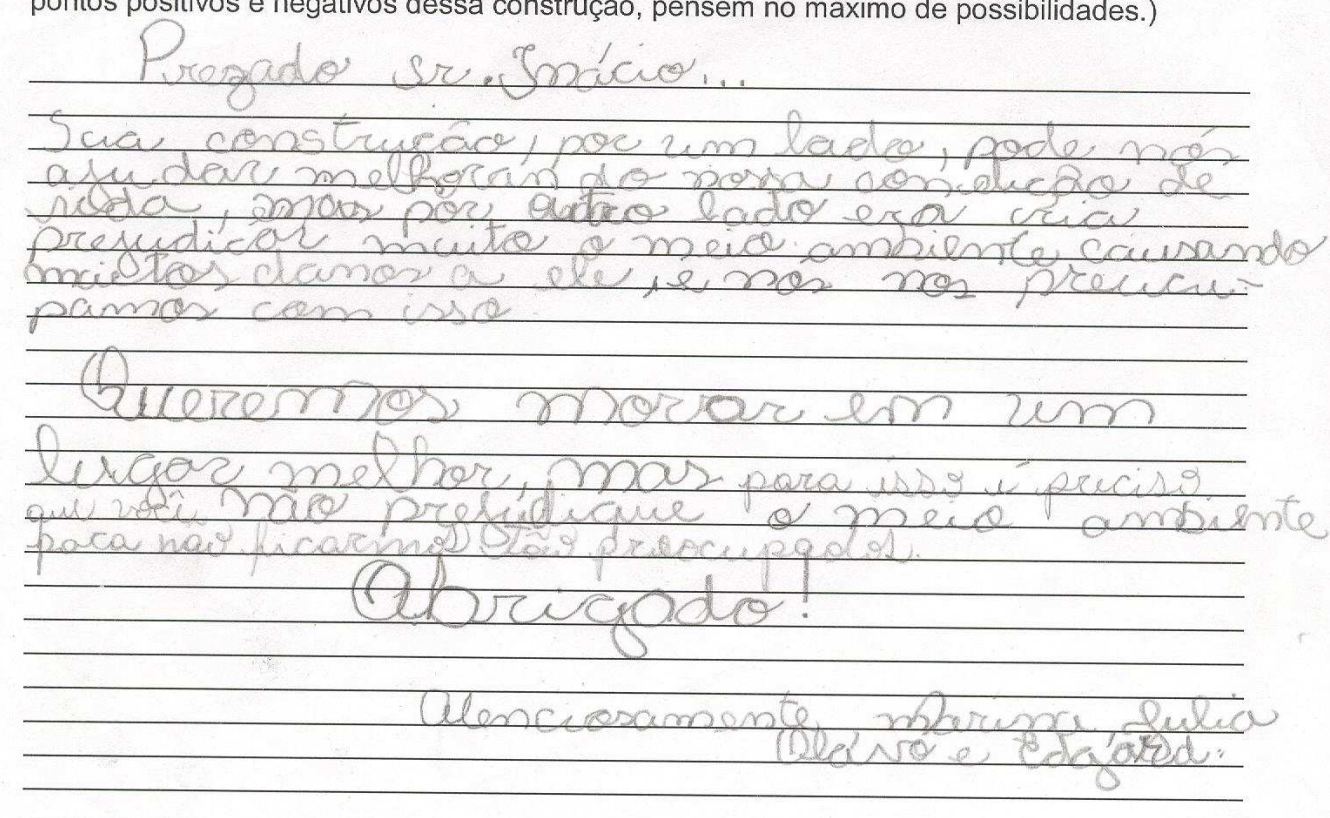

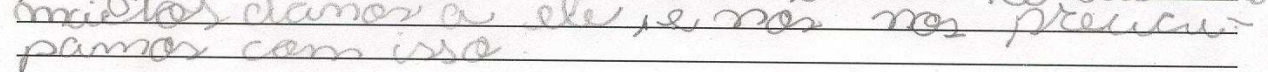




\section{ATIVIDADE: CARTA À PREFEITURA DE SANTO INÁCIO}

Vocês acabaram de assistir a um filme, que aborda uma questão ambiental muito comentada nos dias de hoje.

Imaginem que, na cidadezinha de Santo Inácio, a prefeitura está preste a decidir se permite ou não a construção de um condomínio com luz elétrica, saneamento básico e lazer. Mas, para isso, deverá desmatar uma área de floresta. Então, o prefeito, Seu Inácio, pede aos interessados que escrevam uma carta ressaltando todos os pontos positivos e negativos dessa construção, explicando cada um deles. Dessa maneira, conhecendo todos os pontos de vista, Seu Inácio poderá tomar a melhor decisão.

Vocês fazem parte do movimento ambientalista da cidade, o que vocês escreveriam para o prefeito? (Dica: antes de escreverem a carta, listem os pontos positivos e negativos dessa construção, pensem no máximo de possibilidades.)

Caro Semhor Invicio, wós, os ambrintalis. tos da cidade, estames rotestando solere Q

desmatamente da cidade para a contrabeño

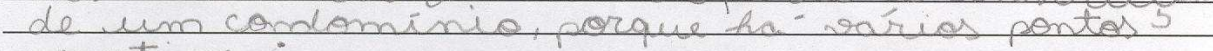
reantingos:

- (1) ar sera mais poluido, pois már terá mous orureres

- Us amionois que moram ha peoresta, perderão inas conas

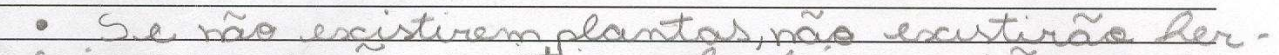

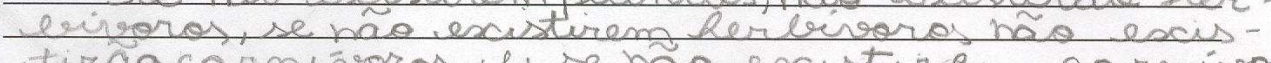

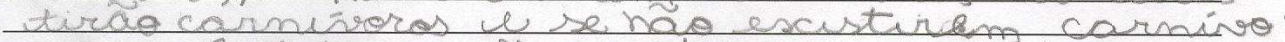

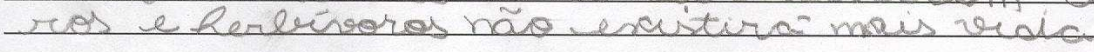

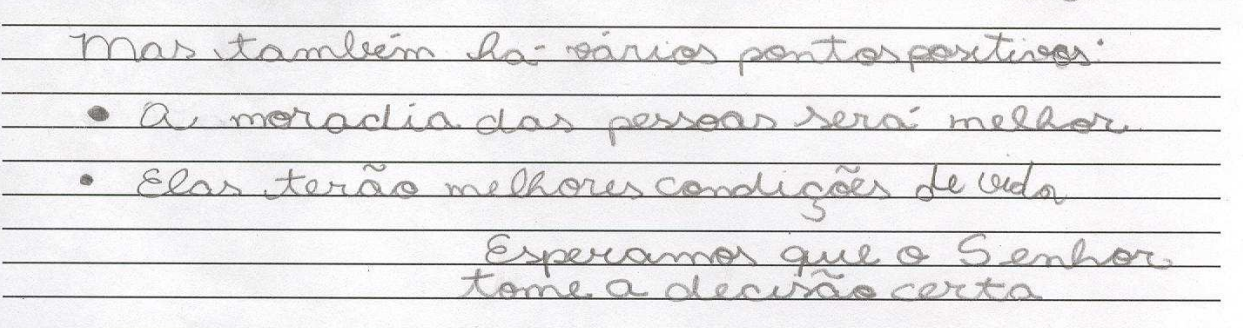
Esperamos que o 5 en 


\section{ATIVIDADE: CARTA À PREFEITURA DE SANTO INÁCIO}

Vocês acabaram de assistir a um filme, que aborda uma questão ambiental muito comentada nos dias de hoje.

Imaginem que, na cidadezinha de Santo Inácio, a prefeitura está preste a decidir se permite ou não a construção de um condominio com luz elétrica, saneamento básico e lazer. Mas, para isso, deverá desmatar uma área de floresta. Então, o prefeito, Seu Inácio, pede aos interessados que escrevam uma carta ressaltando todos os pontos positivos e negativos dessa construção, explicando cada um deles. Dessa maneira, conhecendo todos os pontos de vista, Seu Inácio poderá tomar a melhor decisão.

Vocês fazem parte de uma comunidade que retira seu sustento dessa floresta, 0 que vocês escreveriam para o prefeito? (Dica: antes de escreverem a carta, listem os pontos positivos e negativos dessa construção, pensem no máximo de possibilidades.)

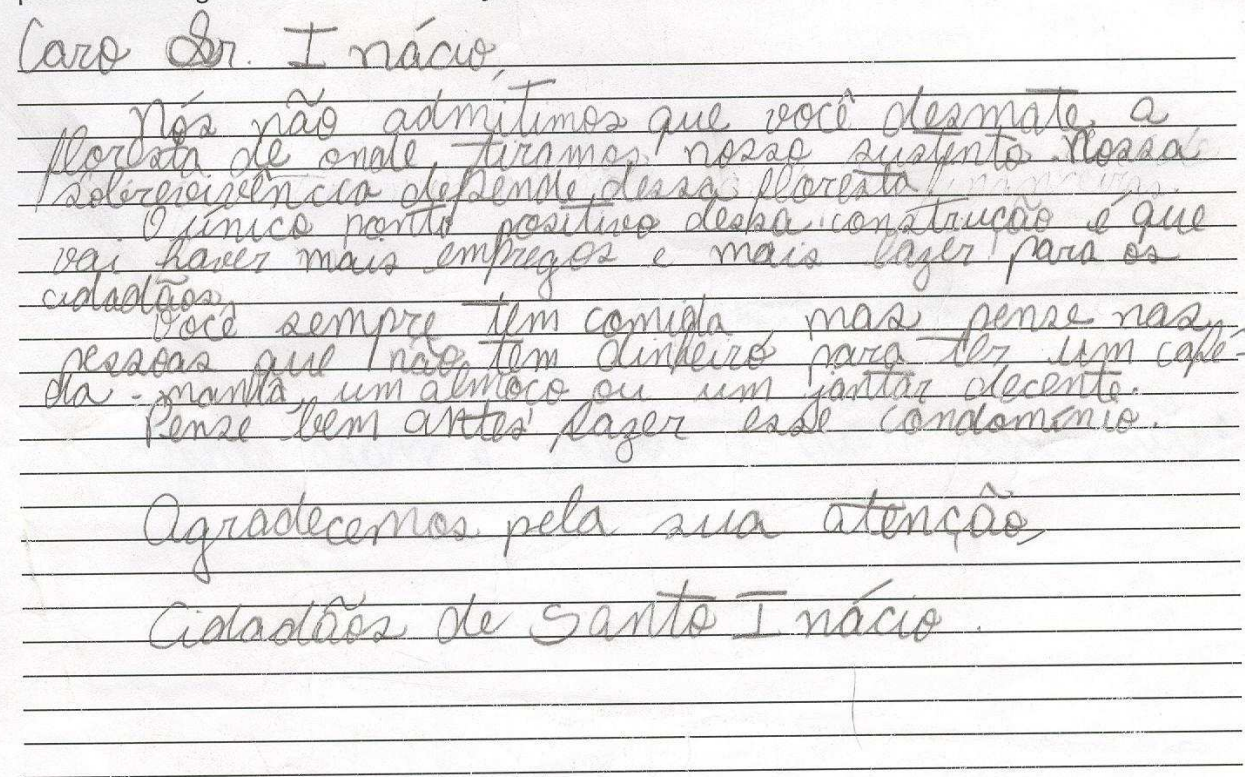




\section{ATIVIDADE: CARTA À PREFEITURA DE SANTO INÁCIO}

Vocês acabaram de assistir a um filme, que aborda uma questão ambiental muito comentada nos dias de hoje.

Imaginem que, na cidadezinha de Santo Inácio, a prefeitura está preste a decidir se permite ou não a construção de um condomínio com luz elétrica, saneamento básico e lazer. Mas, para isso, deverá desmatar uma área de floresta. Então, o prefeito, Seu Inácio, pede aos interessados que escrevam uma carta ressaltando todos os pontos positivos e negativos dessa construção, explicando cada um deles. Dessa maneira, conhecendo todos os pontos de vista, Seu Inácio poderá tomar a melhor decisão.

Vocês fazem parte do comércio da cidade, o que vocês escreveriam para o prefeito? (Dica: antes de escreverem a carta, listem os pontos positivos e negativos dessa construção, pensem no máximo de possibilidades.)

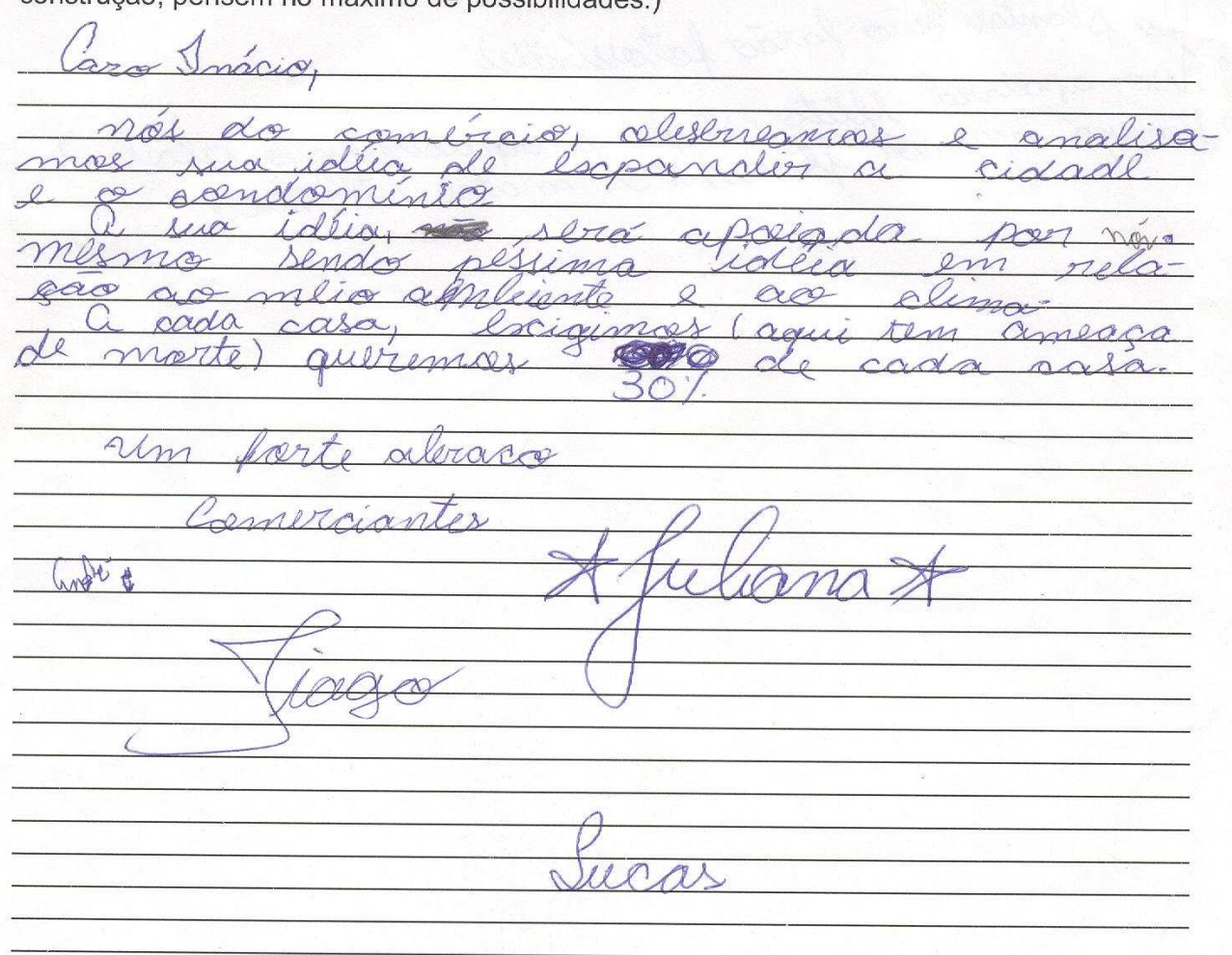




\section{ATIVIDADE: CARTA À PREFEITURA DE SANTO INÁCIO}

Vocês acabaram de assistir a um filme, que aborda uma questão ambiental muito comentada nos dias de hoje.

Imaginem que, na cidadezinha de Santo Inácio, a prefeitura está preste a decidir se permite ou não a construção de um condomínio com luz elétrica, saneamento básico e lazer. Mas, para isso, deverá desmatar uma área de floresta. Então, o prefeito, Seu Inácio, pede aos interessados que escrevam uma carta ressaltando todos os pontos positivos e negativos dessa construção, explicando cada um deles. Dessa maneira, conhecendo todos os pontos de vista, Seu Inácio poderá tomar a melhor decisão.

Vocês são os animais que vivem nessa floresta, supondo que saibam escrever, o que vocês escreveriam para o prefeito? (Dica: antes de escreverem a carta, listem os pontos positivos e negativos dessa construção, pensem no máximo de possibilidades.)
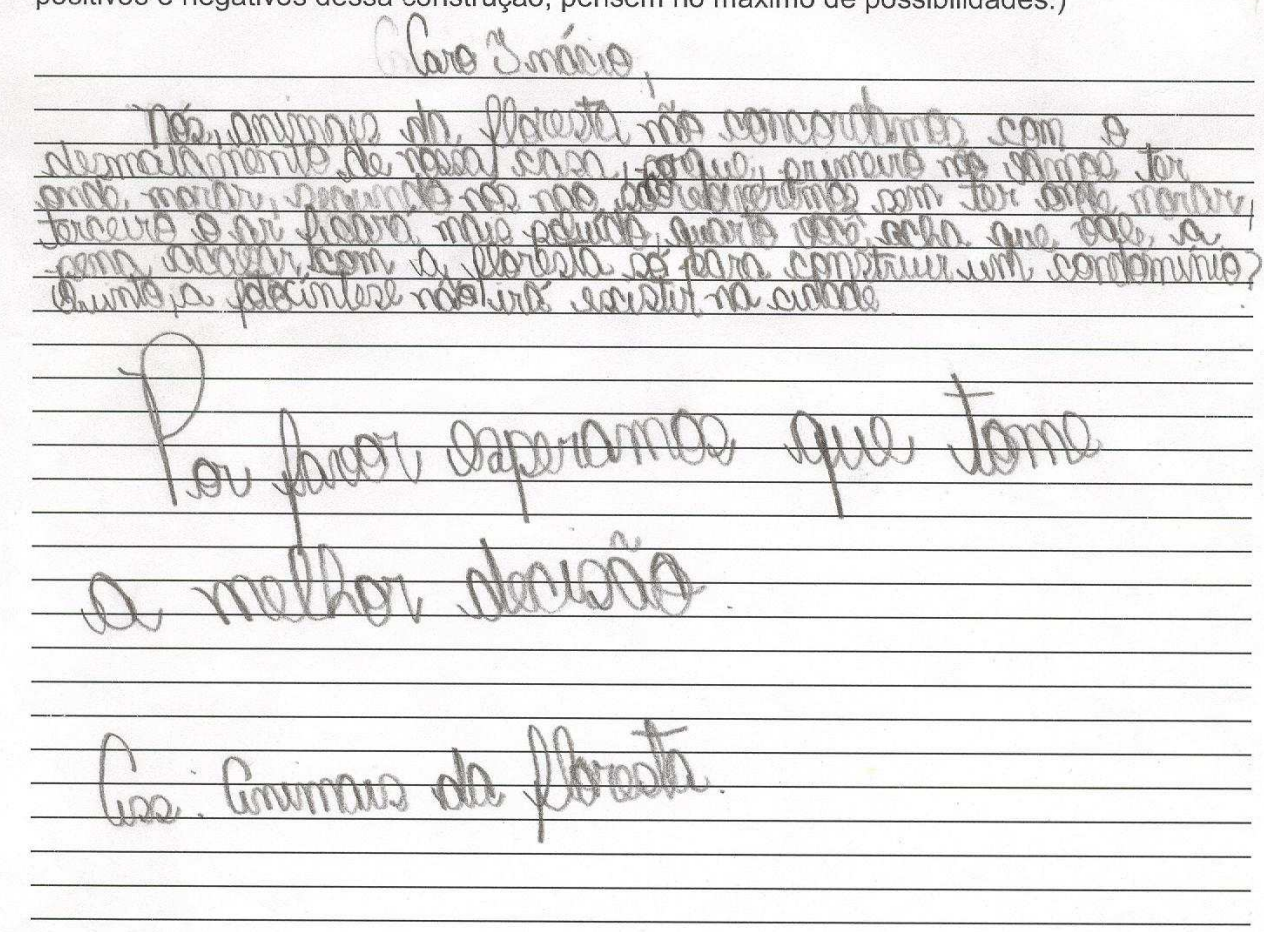